University of Louisville

ThinkIR: The University of Louisville's Institutional Repository

$5-1975$

\title{
A comparison of two smoking reduction treatments under conditions designed to be interfering or not interfering with the smoking habit.
}

Gary Clive Salk 1944-

University of Louisville

Follow this and additional works at: https://ir.library.louisville.edu/etd

\section{Recommended Citation}

Salk, Gary Clive 1944-, "A comparison of two smoking reduction treatments under conditions designed to be interfering or not interfering with the smoking habit." (1975). Electronic Theses and Dissertations.

Paper 1252.

https://doi.org/10.18297/etd/1252

This Doctoral Dissertation is brought to you for free and open access by ThinkIR: The University of Louisville's Institutional Repository. It has been accepted for inclusion in Electronic Theses and Dissertations by an authorized administrator of ThinkIR: The University of Louisville's Institutional Repository. This title appears here courtesy of the author, who has retained all other copyrights. For more information, please contact thinkir@louisville.edu. 


\title{
A COYPARISON ON THO SWOKING REDUCTION TREALENTS

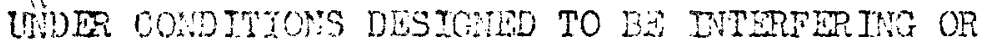

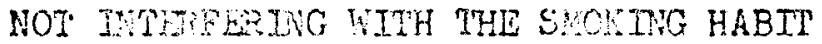

\author{
By \\ Gary Cilve salk \\ B.S., Mohigan stete iniverelty, 1966 \\ K.A., University of Iowa, 1069
A Disgerstion
Submitted to the Faculty of the
Graduate Sonol oi the Univeretty of Ioulsvizle in Pential Fulfizyent of the Feowinentw
for the Degree of \\ Doctor of Philosophy \\ Department of Fsycholog \\ University of loufeville \\ Eolisville, Kentucly
}

Wey 1975 
A COMPRISON OF THO SMOKING REDUCTION DRRETHENTS

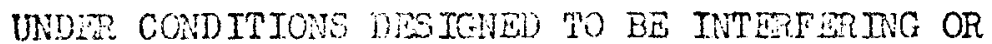
NOT INTEIFETINO WITH THE SNOKING HABIT

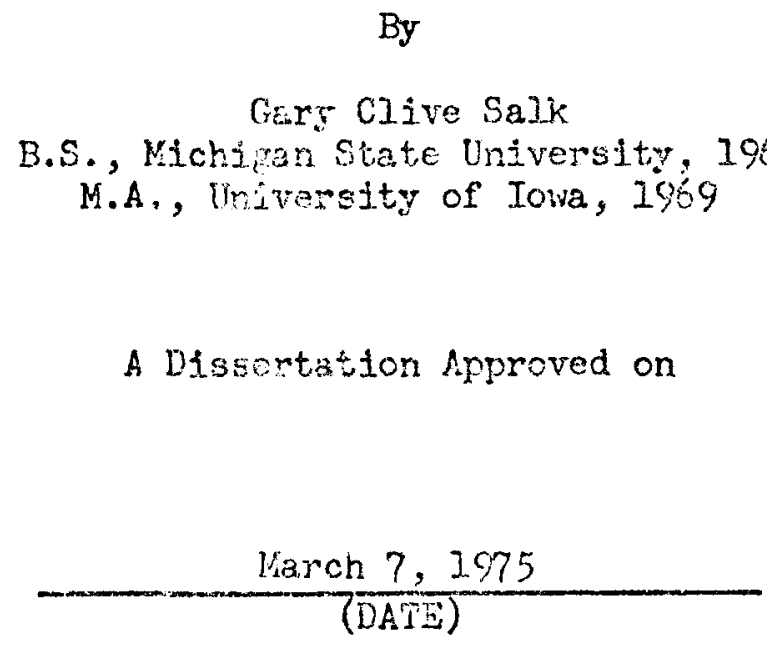

by the Foilowing Reading Comittee:

Dfssertation Director

Dean or Chr iman 


\section{ABSTIELCI}

Thirty snokers were sulicited from the Vichite, Kansas conmunity via the newspaper and broadcast media for a stop-smoking, project. The volunteers were assigned to one of two treatments: double smoking or a modification of Von Dedenroth's (IS64) treatnent. Each of these treatinents was further divided into two groups. These groups were designed to provide high and Iow interference with the smoker's habit. No effect was observed for interierence and it was observed that the experimental conditions probably did not permit the possibility of more than a small interference effect in either group. However, a significant offect for tine and tire by treatments was obtained. The Von Dedenroth groups showed a greater drop in suoking than the doubing groups. Both Von Dedenroth groups were superior to bolin doubIing groups at the threemonth follow up and one Von Dedenroth group was superior to one doubling group at the six-month follow up. The effect observed was apparently a stable diminution in the number of cigarettes smoked by the Von Dedenroth groups. There were like numbers of subjects quitting in both Von Dedenroth and doubing groups. The results were discussed in light of the previous literature. The scarcity of treatment effects, and especially, treatment eflects showing a diminution in snokfing rate in the previous literature was dfscussed. The results were explained in terms of the combined effects of prolonged cbservation by the smokers of their habits and the avallablity of substitute behaviors. 


\section{ACKMOTIEDGMENTS}

Any person so foolhardy or of such unbridled ambition as to enbark upon a doctoral disseriation soon learns that his chances of success are dependent upon the cooperation and support of a good many people. Here are but a few on whom this work was dependent:

Dr. Willard Mainord, my chairman, from whom, true to his wiestern heritage, selriom was heard a discouraging word. Dr. John Birkimer, of my consittee, whose availacility and advice on statistical matters was invaluable. Dr. Perry Fushlau, my boss al Wernersville State Hospital, who deserves credit for whatever felictty of linguistic style this dissertation may obtain. The Peychology Department of Wichita State University for help and advice on all manner of things academic. The members of the Psychology Department of the Wichita Veterans Administration Center, who gave advice cn the politics and praxis of dissertations, and especially their secretary, Ruth Mankins, whose value, like her Biblical namesake, is far above rubies. Mrs. Virginia Bales, whose timely assist at the onset of the experiment enabled it to start on tine. Carolyn Gettier, who typed and retyped the numerous revisions of this dissertation. Finally and foremost, my wife, Dr. Kartha Salk, whose assistance, encouragement and example at every stage of the dissertation and in every way were paramount. 
TABIE OF CONTENTS

Page

ABSTRACT . . . . . . . . . . . . . . . . . . . 11i

ACKNOKLEDGEMENTS . . . . . . . . . . . . . . . . . . IV

LIST OF TABLES . . . . . . . . . . . . . . . . . . viiI

LIST OF FIGURES. . . . . . . . . . . . . . . . . IX

A REVIEW OF THE LITERATURE . . . . . . . . . . . . . . 1

Aversion ................... 2

Information. ................. 11

Imagination Techniques ............. 13

Systeratic Desensitization Therapy . . . . . . 16

Covert Operant Control .............. 18

Assorted Studies . . . . . . . . . . 22

ANALYSIS OF THE SMOKTNG TREATMENT LITERATURE . . . . . . . . 28

METHODS. . . . . . . . . . . . . . . . . . 33

The Search for Subjects. . . . . . . . . . 33

Pre-Treatment Procedures........... 34

Treatment Procedures . . . . . . . . . . 37

Follow Up Procedures .............. 41

RESUITS. . . . . . . . . . . . . . . . . . 42

Personal Data Cards................ 42

Analysis of Vartance of the Base Rate. . . . . . . 44

Treatment Snoking Rates. . . . . . . . . . . 47

Analysis of Variance of Final Data . . . . . . . 47

Analysis by Post Hoc lests . . . . . ...... 52 
Analysis of Raw Data ............ 56

Questionnaire Data................ 57

Obserrational Results.............. 62

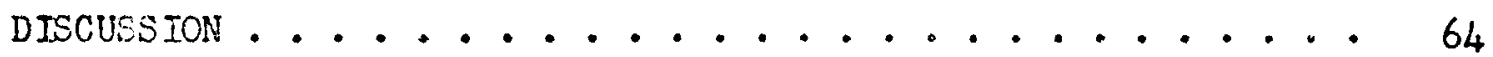

APPENDIX I: NEWSPAPER PUBLICITY OF THE EXPERIMENT . . . . . 72

APFENDIX II: PERSONAL DATA CARD . . . . . . . . . 82

APPENDTX III: INTRODUCTORY STATEMENT AND CONSENT FOFM . . . 83

APPENDIX IV: COVER LETTER FOR FOLLOW UP 1 ....... 85

APPENDIX V: COVER LETTER FOR FOLLOW UP $2 \ldots \ldots$

APPENDTX VI: SMOKING QUESTIOHNAIRE FOR FOLLOW UP I . . . . 87

APPETDIX VII: SMOKTNG QUESTIONNATRE YOR FOLIOW UP $2 \ldots . . .89$

APYENDIX VIII: COVER LETTER FOR SECOND NAIIING OF FOLLOW UP 2 . 91

APPENDIX IK: VERBATIM RESPONSES TO QUESTIONHAIRE ITEM $\lambda$, I. OF

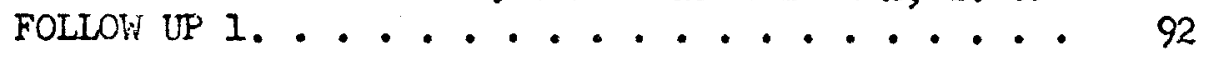

APPENDIX $x$ : VERBATUM PESPONSES TO QUES' IONNAIRE ITEM 1 , I. OF

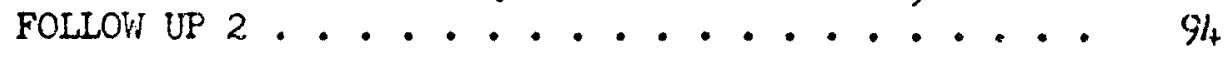

APPENDIX XI: VERBATUM RESPONSES TO QUESTIONNAIRE ITEM 3 OF

FOLLOH UP 1. . . . . . . . . . . 95

APPEADIX XII: VERBATUM RESPONSES TO QUESTIONNAIRE ITEM 4 OF

FOLLOW UP I . . . . . . . . . . . . . . 98

APPENDIX XIII: VERBATUM RISPONSES TO QUESTIONNAIRE ITEM 6 OF

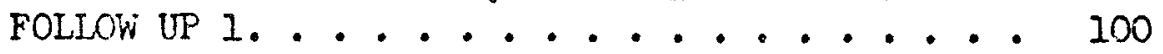

APPENDIX XIV: RAW DATA. . . . . . . . . . 104

APPENDIX XV: VERBATUM RASPONSES TO QUESTIONNAIRE ITEM 3 OF

FOLLOW UP 2. . . . . . . . . 105

APPENDIX XVI: VERBATUM RESPONSES TO QUISTIONNATRE ITEM 4 OF

FOLIOW UP $2 \ldots \ldots 107$

APFENDIX XVII: VERBATUM RESPOISES TO QUESTIONNAIRE I'EM 6 OF

FOLLOW UP $2 \ldots \ldots$. . . . . . 109 
RERELCES . . . . . . . . . . . . . . . . 112

CURRTCULUM VTTAE . . . . . . . . . . . . . . . 117 
LISI OF TABLES

Fage

TABLE I. AN ANALYSIS OF' SUBJECT'S AND NON-SURJECT'S

PERSONAL DATA CARDS . . . . . . . . . . . 42

TABLE II. MEANS AND STANDARD DEVIATIONS OF AIL TREATMENT

GROUPS AT BASE RATE AND FOLION UTS. . . . . . . 44

TAEIE III. SURPRY TABIE OF ANALYSIS OF VAPIAICE OF BASE

RATES . . . . . . . . . . . . . . . . 48

TABLE IV. SUAMARY TABLE OF A 4 EY 3 UNEQUAL N'S ANALYSIS

OF VARTANCE WITH RIPEATED MEASURES OF MEAN IULNBER

OF CIGARETTES SMOKED PLE DAY AT BASE RATE AND

FOLLON UPS. . . . . . . . . . . . . 50

TABLE V. RESPONSES TO ITEM I OF FOLLOW UP QUESTIONNATRE 1:

"HOW WOULD YOU DESCR IBE YOUR SHOKING PATTERN SINCE

THE SMOKING PROJECT?" . . . . . . . . . . 57

TABLE VI. RESPONSES TO MF 1 OF FOLLOW UP QUESTIONAIRE 2:

"HOW WOULD YOU DESCRIBE YOUR SMOKING PA'TERN SINCE

ITE SMOKIING PROJECT?" . . . . . . . . . 58

TAELE VII. KESPONSES TO TTEM 5 OF FOLLOW UP QUESTIONNAIRE 2:

"WHAT IS THE LONGEST PERIOD YOU HAVE BEEN OFF

CIGARETTES STNCE THE END OF THE PROGRAN?" . . . . .60 


\section{LIST OF FIGUNRS}

\section{Page}

FIGURE 1. Mean Number of Cigarettes Smoked per Subject per Day

for each Treatment Group During Treatment Compared

to Base Rates and quotas . . . . . . . . . . . 47

FICIRE 2. Mean Number of Cigarettes Smoked per Day at Base

Rate and Follow Ups for each Treatment Group . . . . . . 48

FICURE 3. Group Percent Ease Rate Snoking at Follow Up . . . . 49

FIGURE 4. Mean Individual Percent Base Rate Smoking at Follow

Ups. . . . . . . . . . . . . . . 53 


\section{A REVIEW OF THE LITERATURE}

The Liraits of this Review

The snoking literature is vast. There are studies on the physiology of smoking, delving into heart rate changes (Bliot \& Thysell, 1968), BaG rhythms (Vurphee, Pfeiffer, \& Price, 1967), physical endurance (Cooper. Gey, \& Bottenberg, 196́6), etc. There are psychoanalytic studies of tine orality of smokers (Jaccbs, Anderson, Champagne, Karush, Richnen, \& Knapp, 1966) and a study purporting to find penis envy and castration anxiety in the ways men and women open cigarette packs (Jandy, 196\%). There are correlational studies showing, for instance, that smokers are taller than nonsmokers (Baer, 1966), and there is a correlational controversy centering around Eysenck's assertion tinat a jredisposition to both smoking and cancer is hereditary (Evsenck, Tarrant, woolf, \& England, 1960). The smoking literature is truly vast and varied.

However, the present work is concerned with the study of outcones of different methods of breaking smoking habits. Therefore, this reviow will focus on the therapeutic studies and more specifically, those therapies available to the psychological practitioner. This last restriction should be no source of jealousy toward physicians in as much as the medical treatments for smoking have, as yet, been rotably Ineffective (Graif, Hamett, Bash, Fackler, Yanovsik1, \& Columan, 1966; Ford \& Ederer, 1965; and Schwartz \& Dubltoky, 1967). 
The Organization of this Review

The review that follows classifies the smoking literature by the technique used to stop or lessen smoking. First will come the major areas into which the Ifterature appears to be divided: aversion, Information, inagination techniques, covert operant controls, and assorted studies. Then under these headings will come the specific techniques. It is realized that any such organization is more or less arbitrary-riost of the treatments involve the management of aversive outcomes of smoking -but it is hoped some increased clarity will cone fron this particular ordering.

Those studies which compare more than one technique will be reviewed completely under the heading of the technique which figured most prominently in the study. Each technique will be reviewed separately, uncontrolled studies firsi, then controlled sturies, and, finally, any studies compring the treatment in question with other tratrents.

Averston

Noise

In what was perhaps the first attempted behavior nodjfication treatment of smoking, Greene (196/) used nojse as a punisher of smoking in a task presented as "music test" to retardates. In this rituation noise interrupted the music whenever the retarded subject lit a cigarette. Kowever, instead of smoking less on the introduction of noise, they smoked nore. Later manipulations showed that the faint click of a photocell relay switw actirated by the glow of the cigarette ash was sufficient to increase snoking rate. The authorg were not 
able to estabitis why this click was reintorche.

Shock

Perhaps the first, and to date most pronising, of the studies using shock on smoking is that of McGuire am Vallance (196/). In their unfortunately brief section dealing with smoking, they reported only one case in any detail and gave only sumnary statistics on nine others. The one case on which there is some detail was that of a 37 year cld woikn who was a 40 cigarette-a-day sinoker who had been smoking for 19 years. She was seen as an inpatient and was shocked on three of five inhaitigs for "several" sessions a day. The inpatient treatment lasted for two weeks and she was then seen as an outratient on a weekly basis. On a six-month follow up she was discovered to be a nonsmoker. Sumary statisizes were prorfied on ten cases and of these six were abstinent on follow up.

Powell and Azrin (1968) devised a cigarctte case that delivered a shock to the left arm when it was opened. Of 20 smokers contacted, six volunteered and only three remained after one day of shock. While the case was worn, the punishrient reduced smoking $100 \%$, $70 \%$ and $30 \%$ in the three subjects respectively. The shock intensity was increased "periodically" until two of the three subjects refused to bear the next highest level of shock. When the device was still worn, but the shock was no longer administered, all subjects resumed smoking at their pre-experimental level,

Garlin and Armotrong (1968) divided three groups of inale sinokers who responded to a newspaper advertisenent into: 1) A group receiving shock contingent on shoking two cigerettes per day for four 
days (conditiontng). 2) Another group recelving random shocks whlle viewing 27 slides two ilmes a day for four days. One third of the slides were "sinoking relevant". 3) A group who were told they were receiving subliminal shocks. In the $2 \%$ hours following the fourth and last treatment, all groups reduced smoking by $40-50 \%$. There was no follow up. In view of the very limited treatment offered this study probably best illustrates short term placebo effects.

\section{Winitman (1969) contrasted grouns receiving: 1) jnformation}

about the negative side of snoking: 2) aversive conditioning where subjects put quinine on their tongues on an FF-3 schedule when they got the lirge to smoke, and if the desire for a cigarette persisted, they self-administered shock; 3) "incompatible behavior development" which meant lcctures on basic learning theory with discussion of each member's attempts to use them; and $4_{4}$ ) a control group who simply recorded their smoking behavior. All groups (except the control group) were seen once a week for one hour over five weeks. None of the treatment groups djffered either at the termination of treatnent or one week later; and at the end of three months, all groups including the control group were smoking comparable anounts. The unfortunate aspect of this study for evaluating the effects of shock is, of course, the confoundIng of shock with the applicaiton of qujnine. Some inkling of Whitman's feeling about the relative powers of the varlous treatments used might be gleened from a later study of his (Whitian, 1972) in which he abandoned shock in favor of an aversive taste substance. This newer study will be reviewed later.

i'he secona study comparing snock to other treatments is that of roenig and lasters (1965). They compared systematic desensititation 
therapy (SDT) a Ia Wolpe and Lazarus (1966), shock administered in the laboratory to 50 of the behaviors comprising the smoking act (e.g., taking a cigarette from the package, lighting it, inhaling, etc.) and a "supportive-counseling therapy". All treatments ran for nine sessions. They discovered no difference anong the therapies. At the end of six months all Eroups were smoking at between $75 \%$ and $84 \%$ of the pre-streatment level.

D. C. Ober $(1968)$ contrastedi: I) transacional analysis, 2) shock (to be self-administered as soon as the subject craved a cigaret,te), and 3) a self-control group receiving instruction in hahit formation ard breaking, and discussions of the difficulties the subjects encowntered in applying these principles to their smoking. The college student subjects in all. groups were seen for ten 50-minute sessions over a four week period. All. three groufs, though statistically indistinguishable, differed significantly from a no-treatment control group at the end of treatment and did not significantly relapse over a one-month follow up.

Steffy, Meichenbaum, and Eest (1970) also used shock in their work, but that study can be more appropriately considered with the covert vocalization studies.

A final study using shock was that of Eerecz (1972), who had undergraduate smokers shock themselves either while smoking or while fragining themselves smoking. He also included placebo, wait, and minimal-contact control groups. The placebo group was placed in the same situation as the shock groups, but was told to turn the shock down until they conld feei nothing. "he treatment groups and the placebo group were seen individually for three weeks, two sessions 
per wok. The wsil group was composed of pacple who were told that they ha been accepted for treatment, but would have to wait a few weeks unt 11 an opening appeared. In the meantioe, they were told to keep records of their smoking. The mindmal-contsct group showed initial interest, but did not follow trwough long enough to start treatweat. They were asked over the phone to estimate the number of cigarettes they were smoking. All groups except the minimel-contact group paid five-dollar deposit. For the women no one method worked any better than any other. For moderate groking males (mean $=13$ cigarettes per disy) both treatment groups were superior to the control groups at the end of treatment and at a six-week follow up. Howevor, for heavy anoking males (nean = 23 clgarettes per day) the Imaginedsmoking group was superior to both the placebo and actual-smoking groups, both at the end of treathent and on six-week 10llow up. Berecs iss able to replicate these resuits.

Hot Snoly Air

It might appear to the uninitiated that hot, smoky air would be a positiva or, at least neutral, reinforcing stimalus to smokers, but wilde (1964), perhaps generallaing from its effects on nonsmokers, conatructed a device that would blow hot, smoky als at a smoker's face while he was omoking and cool, lightly mentlolated air when he would say, "I want to quit smoktrg" and put the cigerette ont. By this method he reported three of his seven subjects quit cigarette smoking, two greatly reciuced thetr moking, and two broke oft the trestment. Frarks, Frted, and Ashern (1956) sollowed Wilde's lead with an tmproved apparatus and ported that of the nine abjects who completed 
the treatment (out of 23 who started), four of the eight responding to a follow up questionnaire were nonsmokers six months later.

It remained for Grimaldi and Lichtenstein (1969) to apply controls to this phenorenon and explore it systematicaliy. One of their groups received snoke contingent on smoking, another group recelved smoke but not contingent on smoking, and a third group received no smoke. NII groups smoked much less than base line on the days during which they were treated, all groups smoked more on a one-inonth follow up, ani all groups were indistinguishable in smoking rate at all poirte.

Niassed Smoking

derome Resnick (1968a) had smoked a pack of cigarettes a day, and after nuerous attempts to stop, in August, 1966, he hit upon the ided of snoking live packs a day for a week and then quitting. He reports that $b y$ the end of the week, smoking had become a noxious act and he encountered ifttle difficulty stopping and staying off cigarettes. He then rounded up eight urdergraduate students and talked to them for a half-hour each explaining stimulus satiation and toli them to bring their smoking rate up to four packs a day as quickly as possible and then stop one week from the interview. One of the subjects did rot comply with the instructions and remained smoking at his usual rate; another complied but was able to stay off clgarettes for oniy two days after treatment; all others ouit and were not smoking four months later.

Resnick (1968b) then set out to look at this procedure more

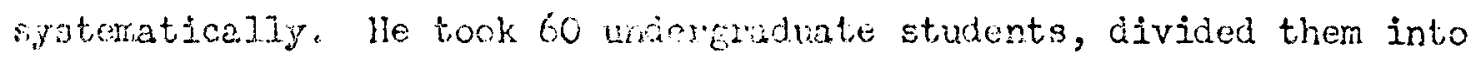


groups of 20 and spoke to each member of each group individually for ten minutes. One group he tola to dcuble treir smoking rate and then quit in a week, a second group were inetructed to triple the ir smoking rate, and the third group he told to remain smoking at the same rate as always for a week and then quit. He reports subjects in the last group readily believed the instructions would work, but those in the first two grours were skeptical [5] He then called all of the students at two weeks and four months later. Al groups exhibited a drop in smoking rate, but the two satiation groups showed a profound drop. At the end of four months, $20 \%$ of the control subjects had quit smoking, but $63 \%$ of the satiation eubjects had quit. It should be emphasized that they were not. "snoking significantly less" or "smoking at X\% of their operant rate", but that they had quit, and ali supposedly as a result of a tenminute instruction.

The work of Schmahl, Lichtenstein, and Harris (1972) attempted to diacover the efificacy of combining warm, smoky air and rapid smoking. They presented their subjects (II men and 17 women, who had an average age of 27.3 years and were pack and a half-a-day smokers) with either warm, smoky a.j or mentholated air, had them light up and inhale every six seconds. They were to smoke on comnand until they could not take it any more. Ait thet point they were instructed to say, "I don't want to snoke" and put out the cigarette. The exhaust fans would then conie on and they would rate the unpleasantness of the trial. As soon as they could otand it, they woulci be forced to start another trial, and trie cycle would repeat itself until the subject would report that he could not take it any nore. The subjects were asked not to amoke between sessions. AlI had quil at the end of the procedure, and at the end of six months a telephone follox: up indicated that g7o were stizl 
absinent. No effect was fourd for hot, smoky versus mentholated air blown in the face of the subject. Some subjects were given booster treatments and, after the third session, a five-dollar deposit was required.

Narston and McFall (1571) attempted to compare stimulus satiation, hierarchical reduction, pill control, and cold-turkey control conditions. The stimulus satiation condition was quite different fron Resnick's (1968b) and will be explainsd sully. The college student subjects were asked to smole three cigarettes everytime they had an urge to snoke, to get cigarettes from the euthoris at the clinic rather thain buy cigarettes, to snoke continertal style, and to record every cigarette. The subjects were seen for five sessions (of unspecified. length and spocing). At the fourth meeting some subfects asked to quit and vere biowed to do so. The hierarchical reduction group also obtained their cigarettes from the clinic and kept recoras of every cigarette smoked. They were to divide the day into four parts and to quit sroking in the easiest part first, then the next easiest, etc., until. they were not smoking at all by the fifth session. They also used relaxation techniques, socjal comitments, coverants, and numercus activities designed to interrupt the smoking act. The pjlI control condition subjects were asked to suck on a non drug spice tablet every time they had sn urge to smoke, and if the urge gersisted, to smoke while sitll sucking on the taklet. They were also asked to change their brand of cigarettes and to think about smoking so as to make it rot a meclarical. act. They also met in iwice-weekly sessions for discussion. The cold-turkey group was just what the nane suggesis--the subjects wore asted to quit and were piven supportive group sessions. 
It is difficult to tel1 how long the treatments took, but it was apparently no less than two weeks in all conditions. There were no differences on follow up between any of the treatments.

The stirulus satiation group did not increase their smoking rore than slightily and, in fact, showed a precipitous drop in smoking less than half-way through the treatment. The reader is not told what the measure consisted of, a Ithough it may be conjectured from the fiures that jt was mean number of cigareties smoked per group.

The flaws in this study are numerous. The satiation group did not snoke at triple their base rate (nor were they actually asked to-they were simply told to smoke three cigarettes at every urge to smoke). The instructions to both the satiation and hierarchy groups included a great deal more than the basic treatment and the synergistic effects of a.Il these instructions are unknown. Indeed, it is not known if the hierarchy subjects followed their instructions any better than the satiation group followed the tripling instructions.

In a study to be covered in more detail below, Keutzer (1968), compared negative practice to breath holding, covert vocalization, and a placebo drug condition and showed no differences between treatments. An examination or Resnick's (1968b) and Keutzer's (1958) operations, however, may serve to clear up the apparent conflict in their results. Keutzer placed her subjects in a closec room and had then smoke three cigarettes in rapld succession, rest, and then repeat the cycle two more times. It is easy to imagine that these njne cigarettes smoked oncera-week for three weeks would not have the same satiation effect as coubling or tripling snoking for a fuld week. 
Taste Aversion

Whitman (1972) used a pill that contained ginger, licorice, coriander, cloves, menthol, etc. as an aversive agent. Also, they were to place this pill in their mouths upon feeling an urge to smoke, let it half-dissolve, and chen light up a cigarette and smoke it while the pill was still in thejr mouths. The subjects were also asked to change their brand of cigareites. One treatment condition followed this regine with group supporit for six one-hour sessions once-a-week and one group did it without the group suppert. Two control groups were used: a waiting-list control and a group of smokers discovered by ra:idom selections from the local phone book. The measure was the subject's estimate of how many cigarettes he had smoked when questioned: 1) before the treatment periud, 2) at the end of treatment (six weeks later), 3) at a one-month follow up, and 4) at a sixmonth follow up. All treatment groups and the waiting-list control grcup reduced smoking with the group-zversive treatment doing better than all others at the end of treatment. Both treatment groups and the waiting-list controls maintained slight, but statistically significant, reductions in smoking at all follow ups, although the differences between them had washed out. The randomly selected control group showed no drop in smoking over time. No therapist effects were shown.

\section{Information}

A "treatment" that surejy must not be overlooked is tho simple giving of information. After all, It could be assumed that the many people who have quit in the last decade have relied on information received from the various media about, the hamfulness of smoking and 
not upon the intervention of paychoiofists.

Nausner (1966) usel this approach and reports that he had so many dropouts that its effects covid not be evaluated. Eighty-two of 206 smokers in his population (a girl's college) indicated an interest in attending a discussion on how to quit smoking. Of these, 17 arrived for the first session, and only four remained for the last session. It is worth noting that this problem of dropouts has been very successfully dealt with by requiring subjects to post deposits to be returned at the end of treatment (e.g., Keutzer, 1968; Elliott \& Tighe, $1.968)$

Lawton (1967) compared an educational group, a therapy group, a group receiving both information and therapy, and a group receiving a concentrated five-day treatment. They dí not differ. All Eroups at the one-year follow up had the same abstjnence rate of $1 \mathcal{E}^{\circ}$.

Leventhal, Vatts, and Pagano (1967) in a complicated two by two by two by two factorial experiment compared fear stimuius (high or moderate), instiuctions on how to quit (given or not given), smoking during the fear stimulus (encouraged or forbidien), and subjects (heavy versus light smokers). Only instructions on how to quit had any effect on shoking rate; an effect still evident three ronths after the experiment. The subjects were Yale students.

The reader will also remember that in Whilnar's (1969) experiment, information proved as good a treatment as aversive stimuli or the conditioning of incompatible responses, but that on the follow up no treatment, including infurmation, had any effect.

In sum, it must be aid that the transmission of information has its place in moking tharapy, espocjally if it is specific instruc- 
tion on how to quate (Leventhl et al., 1967), but that information alone apparently has not had a strong effect on the populations that typically find their way into psychologfeal experiments.

\section{Imagination Techniques}

Hypnosis

Erlckson (1964) reports three crses of heavy sinokers with assorted physical and psycholosfcal disorders whon he treated for smokIng with one session of hyprosis. In follow ups of six months, one year, and two years respectively, they were off cigerettes and, with the excoption of the patient with the six-month follow up who died of heart fisflure at that time, all reported excellent health as well as no relapse in smoking.

Moses (1964) reported the results of 75 patients treated for smoking with bypuosis. Of the 75, 70 were seen for one session (consisting of 20 minutes discussion about the patient's smoking, 20 minutes of lecture by Moses about the evils of smoking, and ten to 15 minutes of hypnosis). Fifty of the 75 patients could be reached for follow ups. Thirteen smokers reported no effect of hypnosis on smoking; 23 were abstinent at the time of questioning; and 24 reported scrae effect ranging from a few hours to 30 -months abstinence, but were smokIng at the time of the follow up.

We now turn to the apparently very successful work of T. E. A. Von Dedenroth, M.D. Von Dedenroth (1964a \& b) in two successive art1cles reports 193 of $200(96.59 !)$ patsents ware abje to give up smokIng at the end of his treatrent. On the last 150 patients (Von Dedenroth, 1964b), no follow up data were glven, but of the f1rst 50 
patents (Von Dedenroth, 1964a) 1,8 were abstinent four to 13 montins later. Such an outstanding success rate clearly deserves close attention.

Information on the last 150 patients is more sparse than on the first 50, so most of the renarks about his patient population will come from this first group alone. The patients ranged in age from 32 to $69 ; 57 \%$ were referrals from other physicians, $32 \%$ were self-referrals, and $I C D$ he advised to quit for medical reasons.

His technicue consisted of an initial one-hour session followed by three 15-to 30-minute sessions over the next three weeks, thus the total treatment takes 21 days. During the initial session, hypnosis was discussed as a method intended to make the individual more susceptible to positive suggestion. Ary fears of loss of control under hypnosis were specifically countered. Then a series of questions were asked: How Iong has the patient smoked? Why did he begin? Has he ever tried to quit? Does he wish to stop now? What benerit does he get from smoking? and specifically, What benefit at what times? and How much does he smoke? He was then told that 21 days from today is "C-day" or "Quitting day". He was told to keep a notebook in which he was to list the reasons why he should not smoke.

He was also asked to enlist the support of his farily, change his brand of cigarettes, and not, to smoke: 1.) before breakfast, 2) one-half hour after all meals, and 3) 30 minutes before retiring. To make his restricted smoking tine easier, he vas on these occasions to go to the bathroom and gargle, clear his teeth, and then notice the Iresh taste in his mouth.

The morning hours were acoonded spectal conidexation. Aside 
from the prow and post-ibreakfast garple and tooth brushing, the patient was to have a glass of fraft fuice or water avallable immediately on rising. Should the desire to have a cigarette strike before one-half hour after bresiffast, he was to talk with someone, drive to the office sans clgarettes, or engage in some other activity unt1l the urge passed.

After these instmetions were given a trance state was then Induced (Von Dedenroth is gratifyingly explictt in his description of exactly how he accomplished this), and the suggestions mode while the patfent was akake were repeated and reinforced.

During the second session, the subject was asked to incresse to one hour the length of abstinence after meals and before retiring. Thts suggestion was reinforced during the trance state. During the third session the patient was asked to curtail or stop drinking alcohoIfc beverages, and it was suggeeted thst although the first puff of a cigarette will taste good, the later puffs will becone progressively more annoyling. These suggestions were also repented and retnforced under hrpnosis. On the last treatment day, "Q-day", a trance atate was imediately induced. Then ft was stressed and Individual had started some good hablts, replaced some bad habits, and becone sware that over the post several weeks cigarettes were getting more and more unpleasant.

Before moving on to the lone controlled study which conld be found, one should note the Kraft and Al-Isas (I967) study (revlewed more fully below) in which hypnosis was used in four of five cases to frduce relaxation. Smokfing was retuced in this study as a concomitant to treating elcoholics for accial arviety. 
Graff, Hammett, Fach, Fackler, Yanovsi, and Goldman (1966) compared hypnosis to "group therapy", chlordiazepoxide, lobeline, and a control group asde up of those who did not volunteer. The results of this somewhat loosely conkrolled study (controls were drawn from a different popujation than treated groups, the amourit of time spent with each group varted greatly, and theraptst effects were confounded with treatrant effects) were that on a threes-month follow up, $88 \%$ of the hypacsis patients, $44 \%$ of the group therapy patients, $22 \%$ of the chlordiszepoxtde patients, and pone of the lobeline patients were abstinent.

Rolomplaying

PIatt, Kraussen, and lausen (2969) got 44 ingle members of a Catholic church group to role-plas eliher a phyglefan or a pasient in a scene where a man is being tolid he has advanced lung cancer, should have an twined late cperstion, and should quit snoking. Thirty-two percent of this group were abstinent at the end of four months, as were $19 \%$ of a group of no-trextinent controls.

Streltier and Koch (1968) hed 30 wonen role-play a cancer patlent with efther a high status person (an I.D.) or a low status person (a coed). Nobody in any group quit smoking.

Systenatic: Deseneitizaition Therapy (SDT)

Morganstarn and Rstiffe (2969) reported the results of SDT on Olght subfects. Oaly four ejther stopped or greatly reduced thes sroking by the end of the flye to six weeks of treatment. The other "reauctions" were slight, no rore than a six-oigarette-per-day difierence from the first week to the last week of therapy. The only other crses encountered of SDT used on snokers were those reported by Kraft 
End Al-Issa (1967). They used hypnosis to induce relextition on four of their five patsents and drugs to induce relaxation on the fifth. The patients were all treated at St. Clement's Hospital, Iondon, where four of the five were inpatients and e.li were elther alcoholics or deperdent on alcohol in soctal situations. Four of the five were between 19 and 23 years old and the fifth was 32 . All were treated for social anxiety with the observed decrease in smoking noted only as a sign indicative of better sociel adinstment. The results of this study are particuzarly difficult to analyze. They could be due to SDT, the youth of the patient.s, the patients' alcohol dependency, or other fretors.

Pyke, hgrew, and Kopperud (1\$56) compared: 1) an "enrlched" growp recelving SDT anch group sesstcns for "discussion, information diskemuntion, and feedibak" (p. 198), 2) \& group which monitored Its sholing for the of.ght weeks that the enriched group was trasted, and 3) ansilics ercup which monjtored tts swoking only during the first and eicth vooks. $M 11$ groups declined stgnificantly over weeks, and 8lthorgh the croups did not sfmificantiy differ, a groupsmby-weeks Interaction obtained significance with the SDT group showing the sharpend decline in smoking. A 2l-week follow up of the enriched group showed a substantial frerease in smoking.

The importance of the monftoring control is emphasized here by the success of the monftoring groups in reducing snoking. NcFall (1970) has explored this variable and noted differences between covertly obtained omoking base rates and those obtained by iselfureport monitoring. When ho asked college sicient smokora to record each clgaretto, covert monitors reported the subjecte increased thest smolking rate. 
Ono other stidy that. may fit under the rubrie of SDT was done by Gerson and Janyon (1972). Theg used SDT for disconfort when not moking, paired with covert senelt iuntion to smoking (relaxing subjects and then reading them sccres of rauses and romlting assoclated with cigarette moking). Th1s senaitizaifon-desensitization group was contrasted with a group which participted in sengitization discussions of smoking. A \$20 depostt was required. At the end of the ten hours of trestnent, both nethods reduced smoking by more than $50 \%$ as recorded by the subjecta on record sheets. Hovever, at the end of a 13 -week follow up subjects' postcard reporte of ghoking for the past week ind1cated a considerable relapse in both groups, but the sensitiationdesensitization group was still smoking signiflcantly less than base rote.

The only study encountered comparing SDT to other treatnents is the prevjously reported Koenig and Masters (1965) work that found SDT, shock, and eupportive counseling indistinguishable.

Covert Operant Control

Honne (1965), in a theoretical paper, suggested that control over smoking could be obtained througin application of Premack's (I959) princlple. The snoker would take a covert behavior that is incompatIble with smoking, e.g., repeating to htmseif "Sroking causes cancer," and increasing the frequency of this covert behavior by pairing it with some high frequency act such as drinking water or coffee and thus decreesing sinoking. The covert behaviox which is lncompatible with smokIng would then occur so often as to reduce the number of occasions when smoking would be possible. 
Keutzer (1960), as mentionea above, compared the use of the above procedure to the following treatments: 1) Breath holding, 1.e., "Whenever you feel the need for a cigarette, hold jour breath until it becones painful." 2) A "massed prettce" condition where the subject Iit and snoked three eigarettes in succession, inhaling on cue, while the experimenter read a script cescribing the evils of smoking. This was repested three tines per session, thus the subject smoked nine cigarettes each session. 3) A drug piacebo control condition. All groups were seen oncer week for three weeks of trestment. All of these grcups were better than a nowtreatment control group, but none of these treatnents was ofgnfficantly betier than any other treatment. This study had many good features in that all treatsent groups were seen for the same arount of time, a $\$ 20$ deposit was required to curtall excess atirition, and there was a large numbex of subjects $(N=246)$. However, the short length of treatment is erucial plaw in the massed-practice group. Snoling 27 clgaredtes under these conditions over a perfod of three weeks can hardly be considered "massed practice."

Gardnar (197.1) compared groups with which confrontation and suppression coverant strategles were tested. These groups were compared to appropriate pseudo-conditioning controis. The confrontation group recelved weekly sesafons in which they listened to their hearts and lungs on a stethoscope whtle snoking three cigarettes. This group was then tcid: 1) to smagine what they had heard in these gessions every tine they had the urge to snoke and to do this every time they engaged in soms high-probubility swoking-related behavior, e.g., ansvering the phose, and 2) to engage in this sequence at least pive thres in succostion at night. The control group for this corkition 
wase to do everything the exparinental grotp did excert that the highprobability behavior was to be in no may connected to the urge to swoke. The suppresston group was scked: I) to Imagine II of the poeftive things they got from anoking every time they had the urge to smoke, 2) to do this frequentiy overy bay and to follow it with sone low-probobility behavior, and 3) to practice this five times in succession every night. The control group for this condition was to attenpt to gatn instght into ecch urge to snoke and to drive it out of thetr ninds by ang means possible.

Five of 28 eubjects in the first exporimental and control groups ccuiblned were not smoking at the end of four months.

Steffy, Keichenbaum, and Eest (1970) rather systemat1cally explored the variable of coverants in relation to smokling. They had four conditions: 2) overt verbalization-action (OVA), 2) covert verbalizstion-action (CVA), 3) overt verbalization-no action (OVNA), and 4) an insight-control group (IC).

Covert verbalization-action (CVA) entajled the subject ImaginIng situation in which moking was probable while actualig onoking. He would be shocked at any time ciuring this sequence if he did not elther refuse to smoke or quickly put the clgarette out.

Covert verbelization-io action (OVNA) extalied the same procedure as overt verbalization-action without the cigarette.

Tine insight-control (Ii) group searched out internal causes of snoking as a contrcl for the advice glven the subjects in the other Eroups.

Each of the groups was divided into two subgroups of six. These suteromps recolved thetr treatment in a group foohion. The 
experimental. groups were seen twicema-week for four weeks. The IC group was seen once-a-week for four weeks. The reason for the control group befng seen for half as much tirie as the treatment group wis that the authors thought of the IC group ss a control only for the advice given in the treatment groups, and not for the amount of time spent with the subjects.

The treatments differed significantly. All groups showed an improvernent over tima, but the CVA (ccvert verbsization-action) group was superior and increased its superiority in the second-and sixthmonth follow ups. At six months after treatment this group riss smoking at $40 \%$ of 1 ts operant rate.

Steffy, et $\varepsilon l .$, explain their unexpected rosuits (they expected that the OVA would be superior) in terms of the 1diosyncratic thoughts and fantasies of the CVA smokers being punished by shock and thus beIng better able to generallze outeide the laboratory then the stereotyped vocalizations the OVA group were asked to utter. One might add that in this sense the CVA group was more "natural" and less "laboratory."

Sachs, Bean, and Korrow (1970) compared three groups drawn from the unfverstty communty: I) an attention-placebo condition which relied on a rather complete smoking diary, 2) self-control group whose members were told to gradualiy reduce their smoking from least to most diffeult situations, and 3) a covert conditioning group whose members had to pair a highly desirable smokirig stination with a highly avergive imagined scene. Of the 37 subjects who started with the treatment 24 completed the experiment with eleht in each group. The mean base rates of each group were $25.875,2.5 .875$ and 15.375 cigar- 
ettes respectively. On a one-month follow up after the three-week treatnent tho two treatment groups disfered stgnificantly from the attention-plasebo controls who had bounced back to within $88 \%$ of baserate. In the covert-conditioning group the effect was due malnly to those who had successfully quit, the self-control group was apparently more successful in reducing thetr snoking whlle not quitting. Sipich, Russell and Tobias (1974) divided 49 subjects into Plve Eronys comparing the effects of nonepeifle treatments with covert sensitization. The groups were: a no-contact control who provided estimates of their smoing rates two times, a monitoring control whose members were told to continue monitoring vitle waiting for a "delayed" treatment, an atiention-placebo group whose nembers were told that they were recelving subifminal messages on the tehchistoscope, a self-control suggestion group and the covert sensitization group. The three trestment groups: covert sensitization, attention-placebo and self-control, were Indistinguishable during and after treatment. However, all three seemed from inspection of the graph to be smoking at about $50 \%$ their base rate at the last (six-month) follow up. The three treatment groups were signiftcantly lower on follow up than the two control groups. The three treatment groups were followed up on a weekly basis for the list ten weeks after trestment and at the six-month point.

\section{Assorted Studies}

Placebo Base Rate

Iichtenstein, Paussaint, Bergman, Jurney and Shapiro (1967) admintetered placebos to 63 patients and noted that $22 \%$ of those complebing four to six weeks of treatruent had etopped or significantily 
decreased smoking at the end of six months. This result is also supported by Funt, Burnett, and Eranch ( 1971 ) who reviewed the evidence pertaining to relapse rates in rot orly cigarette, but alcohol and herion treatment programs too. They found practically identical relapse curves for all. three acdictions, curves which leveled of $f$ at between $25 \%$ and $20 \%$ atstinence at the end of six months to a year. The ir curves were piotted on the basis of 100 abstinence at the end of treatment.

Locking Cigarette Case

Azrin and Powell (1968) devised a cigarette case which would lock shut for a preset period after the extraction of a cigarette. Fo: as long as the timer was in operation the device reduced smoking, but as goon as the timer was no longer set, allowing unrestricted access to the cigarettes, smokine rates leaped to previous levels. I

Therapist Style

Weir, Dubitzky and Schwartz (1969) in a study of three counselors used in the Schwartz and Dubitzky (1967) study reported below found that the most directive therapist had the grealest imnediate success. liovever, at a four-month follow up all counselors' groups had the same, approxinately $20 \%$, abstinence rate.

Cases and Combined Treatrents

Nolan (1968) reports he eliminated smoking in his wife by first rostricting her smoking to a particular chair that faced away from both

I. It may be of interest to note that the Russian Ieader Leonfd Breahnev is reported to carry a similar locking case and that he also carries an extra "cheater" pack in another pocket. 
the orha chetre in the Iiving rocm and the TV set. He then movod the chafr to the basenent. Sach of these moves was followed by a reduction of whoking; but falled to stop now smoking entirely. The desired result did rot come about mil the complained about hel inablitty to stop one day and sudienily quit the nent.

Roberts (2969) in esence replicated Nojan's work on hirself by retricting his sucking to tine bethroom, then adding the restricticns of not recing on talking white molitg. Mose measues were followed by reductions in snoking, but he did not qutt until forced to bed with an Hnees.

Tooley and Pratt (1967) regort exingushing smoking in a ma:ried copje iy using two methods. Minst tha used covert sensitization, that is, the subject was to pair a high probebility behavior, for exanje, drinking coffee, with lon potability betsvior euch as repeating, "Sncking causes cancer." Covert sensitiation was foliowed by reduction in smoking rate, but the smokfng stablified st the lower level awe was not extingufst:ed. The second procedure was then introduced, tive subjects being asked to sign contrats to elintuste smoking. This final iveasure was rollowed by a cessation of smoking for both subjects. No follow up repurts were given.

Elliott and ighe (I968) used a number of treatments to get 20 Dartmouth uriereradiates and five oldex univereity employes to guit smoking. Thej were: 1) An subjects posted a \$ós cash boud to be roturnole in instialnents. 2) sf gned a logalistic plodge to quit. 3) Agreed to have thetr names published in the conpus papor as ex-

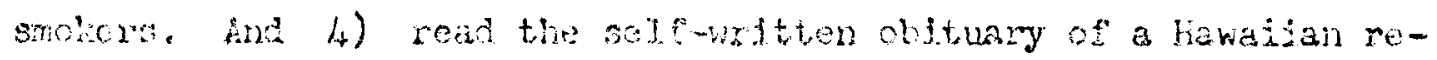

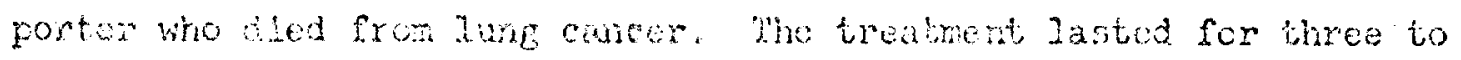


four weeks and all but four of the 25 were abstinent at that tine. On a three- to 17 -month follow up, only $37 \frac{1}{2} \%$ were non-smokers.

Schwartz and Dribitzky (1967) administered a questionnatre to one-seventh of 8 populstion of 8,234 Kaiser Health Plan participants. With an aggressive follow up, they recelved replles from $80 \%$ of their semple and rere able to select 288 subjects from a pool of 396 who had been glven physical axaminations. The large number of subjects made possible a sophisticated factortel design controlled for social class and comparing the effects of individual counseling combined with those of tranquilizers or placebos; to subjects receiving group counseling conbined with elther tranquilizers, placebos, or no drug; to groups recelving just tranquilizers, plscebos, or no durg; to groups receiving just tranqu1lizers or fust placebos. It is difficult to deternine if the results presented sre at the end of treatuent or at the four-month follow up, but treatment success, defired as an $85 \%$ to $100 \%$ reduction In smoking, was ordered as follows: individusl counseling > group $>$ drugs alone, and placebo > tranquilizers $>$ no pllls. The high group, wth a success rate of $50 \% \mathrm{was}$, of course, the individual-counselingplacebo group, and the low group was the drugs-alone-tranquilizer group with a success rate of $16.7 \%$. The average treatment ylelded a success rate of $32.9 \%$.

Chapaan, Smith and Layden (1971) treated cigarette smoking with a varlety of methods including ahock, informetion, recording, social reluforcement, covert reheargal, role playing, outside observers and other measures specifically tallored to the individual. In sddition, a \$100 deposit was used to reduce attrition. In the firot study they report, sil but one of the 12 nonmeollege subjects completely atoppod 
swoking at the end of the five treatment sessions. However, at the first follow up one month later only $33 \%$ were nonmokers and at the three-, s1x-and 12 -month follow ups only $25 \%$ were abstinent. She $1 x$ second sturiy was similar in fornat to the first except that the sub fects were asked to record daily cigarette intake for 12 weeks instead ot three weeks as in study $I$, the outbide observers were asked to make the sarie dally count for the sane 12 weeks, treatnent was extended to 10 sessions if abstinence did not cone before that and subjects were expecied to return for booster sesgions if thoy relapsed during the first weel after ureatnent. One of tho II subjects was not abstinent at the end of treatment and the follow ups of one, three, six and 12 months showed respectively one, two, five arid fivc of the $I I$ subjects to be amoking at these follow up points. Although the results of at Jesst the second study are impressive, it 13 impossible to dissect out of the many methods used which methods or combinations were effective. A surmary chart of the more important studies that have been ieviewed follows:

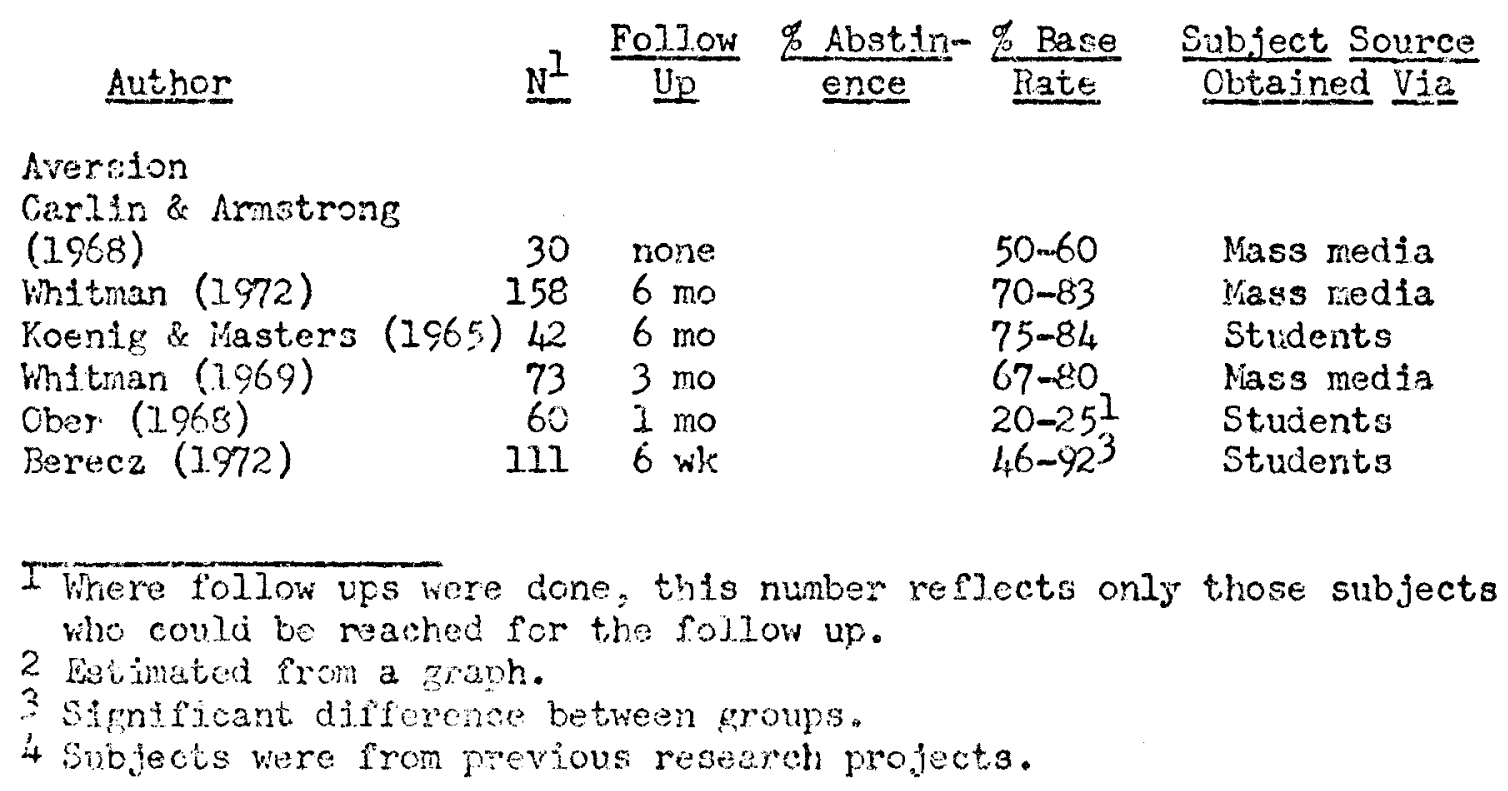


Author $\quad N^{2}$ Foilow BD Abstin- Ease $\frac{\text { Subject Source }}{\text { ence }}$

Grimald \&

Lichtenste in (1969)

Resnick (18686)

$29 I$ mo

$604 \mathrm{mo}$

Schmahl, et al. (1972) $25 \quad 6$ mo

Marsten \& MeFall(1971) 636 mo

$\begin{array}{lll} & 50-66^{2} & 4 \\ 20-63^{3} & & \text { Students } \\ 57 & & \text { Students } \\ & 64-78^{2} & \text { Students }\end{array}$

Information

Lawton (1.567)

915 mo $\quad 11-20$

Mass media

Hypnosis

Moses (196it)

Von Dedenroth (1964a) $50 \quad 4$.13 mo 76

Grati, et al. (1966) $24 \quad 3$ mo $0-88$

Patients

Patients

Mass media

SDT

Pyke, et al. (1956) 1519 wh

Gerson \& Ianyon (1972) 21 13 wh

$\begin{array}{ll}83 & \text { Students } \\ 65-85^{2} & \text { Students }\end{array}$

Covert Operant Control

Keutzer (1968) 146 none 3-33

Gaverer (1971) $28 \quad 4$ mo 38

Steffy, et aI. (1970) 48 mo

Sache, et al. (1970) $24 \quad$ I mo

8

Mass media

Mass medie

Students

Students \&

Mass media

There foilow ups were done, thits number reflects only those subjects 2 who could be reached for the follow up.

2 Estinated from a graph.

3 Significant disf ference between groups.

4 Subjects were from provious research projects. 
ANALYSIS OF THE SHOKMG TREATMENT LITERATURE

From the review that has preceded several points become evident. First and most obvious is that very few of the trestinents worked better than the $25 \%$ abstinence base rate a iter $31 x$ montha (Hunt, Barnett \& Branch, 1971). In fact, very few of the studies even reported thedr resuits in the percent abstinent formet. It is Lichtenstein's (1971) opinjor based on "anecdotal and empiclcal evidence" (e.g., Aarin \& Yond1, 1968; Iichtenstein \& Kentier, 1971) that snokers who do not quit bot simply recice their smoking are very likely to return to their prewtreatment smoking rate. lmong the few studies that may have exceeied this abstimence buse rate are Resnick's (1968b) and Von Dedenroth's (1964a \& b). Resnick found 63\% of his subjects cleined abstinence when called four months after treatment and Von Dedenroth (1964a) claimed $96.5 \%$ of his patients were abstinent at follow ups of from four to 13 months.

Resnicl's results are not clear because he made no effort to ascertain if his subjects actualiy did follow his instructions. When Narston and McFril (1971) perfomed a modified replication of hte work, they found that most of their subjects did not follow the regimen. However, netther did they get Fesrick's high abstinence rate and the question otfil remains as to whether the treatment works when it is followed. It w1II be remembered that when Schmahl, et al., (1972) combined hot, smoky atr with rapid omoking and prohfbition of snoking outside the Iaboratory, they got a $57 \%$ abstinence rate at a sismontho' phone follow up. Insemuch as the group that got hot, makgr air and rafld sioking 
did not differ from a group that got mentholated air and rapid smoking, it would seam reasonable to conclude that the rapid sinoking may have had sone part in the success of the treatment. However, Schnahl, et al.'s, (1972) treatment requires an elaborate laboratory setting with exhaust fans and smoke blowing equipment that is not available to the averege clinician. Thus, if a tighter test of kesilick's more simple procedure would show that his meshod, when followed, could yield comparable success to Schmahl, et al., (1972) it would be a boon to the practjeing clinfcisn.

Von Dedenroth's (1964a \& b) work is also in need of a tighter experimental test. His work was essentialiy a compilation of case studies, with very little data being given about possible attrition rates, specific follow up periods, follow up procedures, or the nature of the populations with which he dealt. For example, vere his subfects suffering fron serious medical conditions that could have been caused or exacerbated by smoking? Given these methodologicel shortcomings and the suspiciously high abstinence rate of $96.5 \%$, Von Dedenroth's work would seem in need of replication and explicstion.

Two other reasons for the consideration of Von Dedenroth's work are that: 1) his treatnent occurs in the smoker's natural smoking setting and, 2) can be integrated, at least temporarily, into the smoker's life. Other wrlters (Hunt, 1973; Hunt \& Matarazzo, 1973; Nausner, 1971, 1973) have felt that the lack of thesa two related factors has been a cause of failure in previous smoking traatments. It should be noted that Resnick's work also meets these two criteria.

The Reentck and Von Dedenroth procedures occur beyond the walls of the laboratory in the subject,'s nomal envtroninent. The only part 
of ether's precedure esried out in the consulting room, aside from Lingtrictsors, is the hypnosis in Von Dedenroth's work, and it is such a small part of the treatment as to raise questions of its necessity. Both trestmentg are also able to be integrated into the smoker's Iffe. In nejther case is there a plece of cumbersome apparatus to be earried about and in neither case is their a great expenditure of time that might prove disruptive to the subfect's daily routine.

Another feature of Von Dedenroth's treatment is that it filla the smoker's life with things to do instead of smoking and thus must surely enhanee feelings of self-ecntroi.

There 1s, however, a further reason for examining these two worke thst springs from more abstract and less pragmatic considerations. By appealing to cinical lore and ouservation, it could be noted that, for the mature smoker at least, smokfing belnavior seems to be cued by a large number of stinuld and that these stimuli are often idiosyncratic in nature. Thus, It would seem reasonable to assme that sny treatment which is capable of breaking up a large number of the bonds between these simuli and the smoking response would be a cand1dote for a successful treatment. In other words, if smoking can be thought of as a response which has been conditfoned to a large number of triggering events in the smoker's life, then any treatment. which is capable of dismupting these bonds should be successful.

Inherent in this statement is a theory of how smoking is learned. It is felt that the smoker may be impelled to anoke as a young person for relatively few reasons. For exarple, he nay start sinoking to look more mature, to "be one of the gang," or to "izave something to do with my hands at parties." However, with repeated practice 
gmoking may become associated with a large number of cuing gituations and may serve many functions for the smoker. For example, some snokers report always Ilghting up when someone whom they expect to be disagreeable walks into the room; others never smoke when reading, driving or engaging in other specific activities; other smokers may be very consclous of time factors in their smoking and thus always smoke immedLately on rising, when they take their $100^{\prime}$ clock coffee break or just before retiring. Thus, there are many things that may trigger smoking, these cues may vary from smoker to smoker and may be of a very lidiosyncratic nature depending upon the learning hietory of the individual.

The effective gmoking treatment then should be one which operace in the smoker's natural smoking environment where these cues exist, snd one which is somehow broadly disruptive of a great number of ettrauli for smoking.

It appears that both Resnick's and Von Dedenroth's methods apparently meet these criteria. If the amoker follows Resnick's plan and doubles his smoking rate, his actions could be viewed as forcing him to etther find twice as many events whitch would normally trigger his smokIng or he must start smoking simply to meet his quota for tire day. With this, the new habit of emoking to meet a quote would be establianed and the individusi may be smoking whether or not those events which previously cued his snoking are in the enviroment or not. Smoking would, thus, be conditioned to everything ard diserfinination world break down. Also, with this treatrent it could be seen that in time the very act of amokirg might becone obnoxious as the smoker gets twice as much stimulation of his throat, lungs, and nervous eysten as he previously found pleasent. Thus, de the treatment week vears on it vould be said that 
not only will the events which previoualy cued amoking be dismupted, but the response itself will be nunished.

Likewise with Von Dedenroth"s treatment the smoker's Iffe for the time of the treatment is 111 led with other things to do Instead of Emoking. The smoker is busy repeatedly brushing his teeth in the morn. ings, ignoring cues to smoke at ppecified tines of the day, engagtng in the incompatible behavior of listing reasona why he should not smoke, etc.

Hypothesis

Given the above considerations, this study sought to explore the dismption variable in these two treatments. It is specifically hypothesized that subjects who are given instidctions to dismupt their smoklng maxtrally will show higher abstinence rates and gmallex percent of baseline smoking rates than groups which are glven instructions in tended to minimize the disruption of their smoking. 


\section{NETHOES}

The Search for Subjects

The search started on March 6, 1974 with a 28-column-inch story (with a photograph of the smiling "smoking researchor") on page flve of the Wichita Eagle (see Appendix I) opposite the editorial page. The story evidentily caught the fancy of an editor at the Eagle as Robert Heaton, one of top feature writers of the Wichits Eagle and Beacon newspapers, was assigned by his edttor to participate in the study and write about 1t. There followed fron this essignment a series of usually accurate and often amusing storles over the course of the experinent, including two front page storles. The toial newspaper coverage by Wichlta's two daily papers vas in excess of 130 colum inches (see Appendix I).

The radio and television media of Wichita were also generous In giving publicity to the project. On the afternoon of March 8 , the Investigator was interviewed on the KAYE-TV noon news program; on the morning of March 13, excerpts from an interview the night before vere aired on the KWBB radio morning newscasts; and spot public service announcements were arranged for and, hopefully, alred on five radio etstions. The experimenter went through the requisite procedures for having a public service announcement alred on the aforementioned five redio siations, but he cannot verify that the spots were indeed aired. These measures fasled to $y$ leld tho hoped-for 80 subjects at the firat organlzational meeting, therefore, the start of the program was postponed for a week in the hopes that continuing publicity would Ilash out nore anbjects. However, when tho necesary preilmingiries 
wero comyleted, only 27 people were ready to start the treatrent phase of the program. Twenty-six of these 27 persons actually completed the treatments. Although disuppoinising, such a omall return for \& large effort is not uncomnon in smoking tregtment research (ksusner, 1966; Gutran \& Marston, 1967).

Because 26 subjects were far fewer than hoped for, anotiner smoking clinic was offered after the completion of the first through the good offices of a Wichtta Hethodist minister who was a subject in the first rus of the experiment. He assured the experimenter that many of his parishioners had expressed a desire to quit smoking and that \& story in his church newsletter plus the continuing publicity in the wichlta daily papers would yield meny additionsi subjects. Four new subjects were obtained by this meons. Six attended the inftial meeting, one never was seen or heard from since, and another tapered off and quit in the baseline period. The remalning four were divided in half and assigned to two of the treatment groups. The treatment given these later subjects differed from the earlier subjects only in that there was no waiting period between the end of the baseline period and the start of the treatment period.

\section{Pre-treatment Procedures}

Heavy cigarette snokers (smoking greater than 20 clgarettes per dey) were solfclted as subjects, but when the shortage of subjects becane acute, four persons whose base rate was less than the requialte one pack per day were allowed to remain in the study.

When prospective subjects inftially contacted the experimenter, they were inforned who the experinenter was and wity this research was 
being conducted, of the time and place of the orfentation meeting, and that they should bring a $\$ 40$ deposit. They were also told the deposit would be returned in stages upon successful completion of each phase of the progran. It was explained that this mcasure was designed to reduce attrition. In the first and second orientstion meetings the basic outline of the research was explained and the following points were covered:

1. Personal data cards were passed out and the prospective su'jjects were asked to complete them (see Appendix II). These cards contained questions about the prospective subjects' smoking histories and health. The health items consisted of a list of diseases which physfciens at the Wichita Veteran's Administration thought coujd be exacerbated by double smoking. The persons at this initial meeting were asked to check those diseases from which they suffered. Those persons who were so afflicted were asked to obtain a physician's waiver before participation in the program. As any person could be assigned to the doubling condition, those who had one of the above 111 s and could not obtain a medic's walver were excused from the program.

2. All prospective subfects were asked to collect smoking base rate data for one week prior to the start of treatment and were told they would be asked to return questionnalres and three-day diaries of smoking at three and $s i x$ months after the end of treatment. Smoking diaries were passed out on which the subjects were asked to record the t.dne and situation of each cigarette as they smoked it during the base rate and treatment phases of the experiment. The diaries were sized to sit into an ordinary clgarette rack (approximately iwo by three and one-half inches) and the subjects were asked to carry the diariea slld 
under the cellowhane of their cigarette packs. They were cationed to record a.11 cjgarstes, even borroved cigarettes, on the enoking diaries as the data thus obtained would be used in formulating an Individualized plan for each person.

3. All subjects were asked to sign a sheet indicating they had read a description of the treatment and its attendant risks, and to certify that they were rolunteers (Appondix TII).

4. Questions were entertained and enswered.

5. The deposit of $\$ 40$ was collected. Thfs deposit consisted of three checks of $\$ 20, \$ 10$ and $\$ 10$ made out to the American Cancer Society. The deposit was refunded in instaljuents of: 1) $\$ 20$ for completion of the treatment, and 2) \$10 each for sending in the threeand six-month follow up materials. The prospective subjects were told the deposits would be returnec independentiy. Thus, a subject who failed to complete an earlior part of the progran could silll receive money back for completion of later parts of the program. If the subject did not complete one or another of the experinental taske, the forfested part of his deposit was contributed to the Anexican Cancer Society.

6. The subjects were asked to return one week later with their completed smoking diaries.

7. The group was then roughly divided into four parts by dealing the personal data cards into four plies. The piles of cards were asstgned one to each of the four treatment groups.

At the last pre-treatment meeting the subjects turned in their diarles which were quickly scanned to see how accurately the subjects had complied with the instructions. When this task was completed, the subjects kere told when to report for their respective treatment groun 
meetings.

\section{Treatnent Procedures}

AIl subjects were asked to continue keeping smoking diaries for the duration of the treatment.

Doubling-high Interference Group (D.HI)

Each member of this group was given a sheet on which his high probsbility snoking times and situstions were printed as ascertained by Inspection of his diary. The subject was then told to at least double his snoking during these tines and to make certain that at the end of each day he had snoked at least twice as much as his base rate. Each subject had his baae rate per day and new daily quota of double the base rate printed on his sheet. The subject was further instructed that should any other situstions arise which he knew to trigger his smoking, he was to at least double during these as well. The subjects were given new smoklng diaries and were told to keep them for the duration of the treatnent week. The experimenter also delved briefly into the dangers of smoking and gave a short explanstion of the value the procedure had demonstrated in the past.

Because of the difficulties involved in getting people to actually double their smoking rate (Narston \& NeFall, 1971), a great deal of stress was lafd on the subjects truly doubling their smoking during the treatment week. The subjects vere also asked to supply the name and phone number of some person who might, reasonably be expected to have knowledge of their suoking rate. They were told the experimenter inight attempt to contact this person at least once durfng the treatnent to get an indepondent qualitative check on their amoking rate. 
This was an empty threat as no euch individual was ever contacted.

The group was told to meet for one hour or less each wcek day during the treatment week for support and encouragement. During the se sesstons each subject's smoking rate for the previous day wis reviewed with laggards exhorted and successful subjects praised.

The subjects were reminded that the return of the $\$ 20$ portion of thein deposit depended on their keeping their diaries up-to-date and turning whese diaries in at the end of the treatment week. They were also reninded that the content of what they turned fn would in no way influence the return of their depostt. They were told the experimenter was interested fin cccurate data and that he had no interest in fooling himself into beifeving that a snoking treatnent worked when it did not.

Dovibling-low Interference Group (D-Lo)

This group was treated in exactly the same way as the D-HI group except their sheets Instructed them to increase their smoking during perfods in which they would normally not smoke, the intent belng to minimize the amount of disruption of their already existing smoking habits. This proved to be a very difficult task, as it was easier to discern commissions than onissions. All other instructions and meetIngs were the same as for the Dwil group.

Von Dedenroth-high Interference Group (V-Hi)

The subjects in this group had their base rate records analyzed in the same inanner as was done for the D-Hi subjects. That is, high smoking periods were identified, wen the group met again after this andysis was done, each subject wa given to enet of paper on which his five highest rate emoking perlods wore indicated. 
The subjects were told three weeks from the first treatnent day was "Q-dry" or" quitting day. They were asked to change the1r brand of clgarettes and to keep a notebook of reasons why they should not smoke. The subjects rere asked not to smoke for one-hish hour during the perfods listed on their sheets and were Elven alternstive behaviors to perform during those times. The particular form of the alternative behaviors differed depending on the time of day and the subjects' routine.

Alternative behaviors included having the subject:

1. Have a glass of water or juice to drink immediately on rising, gargle ard brush his teeth while noticing the fresh clean taste In his mouth.

2. Gargle and brush his teeth afier breakfast, lunch, and dinner If possible. If the urge persisted after breakfast, then he was to go to work without clgarettes or find some other activity to occupy the time.

3. Leave his cigarettes behind hin, seek the company of some nonsmoking friend or colleague, and then work or talk with him.

4. Ask a nonsmoking friend to "watch my cigarettes for a whlle" and leave thein with the friend for the duration of the periad.

5. Ieave the cigarettes in one part of the house and work in another.

6. Savor a cup of coffee or other beverage that the subject normally does not associate with smoking.

7. Duive hone from work without cigarettea. If the subfect doea not drive home or ortves with other smokerg Irom whon he may be tempsed to borrow a cligrette, he wholid recount for his prosengers 
or fellow combiters the most pleasant event that happened to him that day.

8. Chev gun or flavored toothptcks.

9. Make entries in a notebock of reasons why he should not smoke. This list was tallored to the Individual circunstances of the subject, thus if one person's work schedule did not permit one of the altennative behaviora, new ones were suggested or behaviors normaliy - Agasted for other time perjods were used. As ail subjects were asked to keep a notebook of reasons why they should not moke, naking entries in the notebook served as a general backup behavior in alz of the time perfods of the day.

At the second session one week later, the smoker was requested to Increase the length of abstinence in the previously ldentified periodis to one hour. The subjects were agatr asked to change tineir brand of cigarettes, this time to a less destrable brand. The remainder of the session was taken up with group discussion and encouragement. At the third session the subjects were asked to curtail ot stop drinking alcoholic beverages as Von Dedenroth (1964a) felt smokIng and drinking were often paired. It wes also suggested that a. though the first puff of a clgarette would taste good, the later puffs would become progressively more annoying. There suggestions wes repeated and refnforced during the discussion. On the last treatrient. day, "Q-day", It was stressed and restressed that the subjects had staried some good hablis, replaced some bad hablts, and had begun to notice that for the past severat weeks cigarettes had become more and more unpleasant. 
Von Dedenroth-low Iriterference Group (V-Io)

This group was treated the same as the V-H1 group except that Its base rate records were combed for times during which the smoker did not habitually smoke. As with the D-Io group, it proved difficult to find patterns of when a person did not moke.

\section{Follow Up Procedures}

At three months and six months after the completion of treatmerit each subject was sent a malling containing: smoking diaries sufflclent for three days recording, a questionnatre, a letter of introduction asking him to record each cigarette for the next three days and to fill out the questionnaire, and a stamped return-mail envelope with which to return these materials to the experinenter. It was noted that; accurate completion of this task was necessery for the return of the remalnder of the deposit money.

The letters sent may be seen in Appendicies $I V$ and $V$, and the questionnatres in Appendicies VI and VII, each for Follow Ups $I$ and 2 respectively.

At Follow Up 1 those who did not respond in a reasonable amount of tine were phoned and reminded. On Follow Up 2 another mailing containing a new letter (see Apperdix VIII) and another copy of the FoIlow Up 2 questionnaire was sent to laggards. When these messures failed, the individual was called unt 11 a response was obtained. 


\section{RESULPS}

\section{Personal Data Cards}

There were eleven potentiai subjects who returned their personal dats cards (see Appendix II), but who did not continue with the experiment. An analysis of the responses of these eleven people versus the thirty who completed the treatment phase of the experiment should provide some indication of any differences between the treatment sample of smokers and those smokers who show sone interest in a program such es this but who do not continue to the treatment phase. These differences might also provide sone general outlines of the differences between the treatment sample and smokers in general.

A comparison of the tiwo groups may be seen in Table I. The two data wich are anenable to statistical analysis (age at onset of smokIng and longest time off cigarettes) show significant differences on two tafled $\underline{t}$ tesis. The subjects reported starting smoking later and being able to quit for longer periods of tine than non-subjects. The data not amenable to stat1st1cal analysis were number of times which the person quit smokjing in the past, estimated smoking rate, and mean number of diseases.

The difficulty in the analysis of the number-of-times-quit item was that a large number of subjects gave indefinfte answers such as "none - sort of", "too many times to count", "25 or 30 times", etc. Of those who gave numertcal arswers of any sort, means were computed and used. Those peorle who gave figures which indicated a zange were asafgnel the mean value of that range for computationa? purposes. 


\section{TABTE $T$}

AN ANALYSIS OF SUBJECT'S AND NON-SUBJECT'S FDSOINAL DATA CARDS

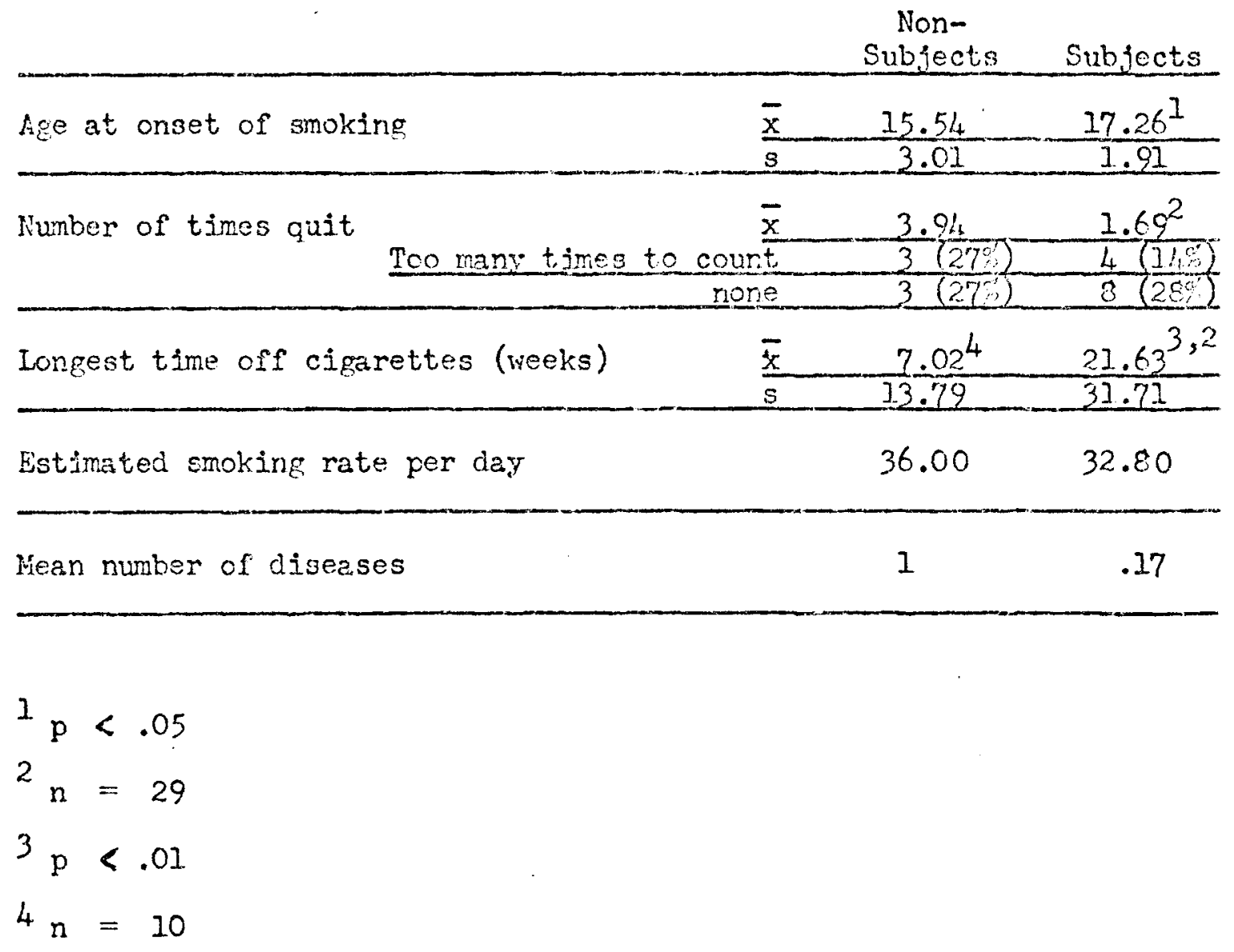


The estimatedmokingmote fiem presented similar problems. Mray people gave indefinfte responses such as "about li packs" or "I to 2 packs." Again, those people who gave ranges were assigned the mean value of the range. A compartson of the estimated smoktng rates with the tallied base rates for those subjects on whon base rate data are available shows that there was a consistent tendency to overestinate smoking rates. The subjects' base rate was 27.9 as opposed to their mean astinatie of 32.8 . The two non-subjects on whom base rate data are avallable both overestimated their smoking rate by seven cigarettes each. In fact, of the total 32 persons on whom base rates were ava11able, only two underestimated their smoking rate.

The data on number of diseases was not analyzed statistically because this variable was the reason why some of the non-subjects did not participate in the study and ras thus a selection variable. Also, the absolute numbers inrolved were very small for both groups.

\section{Ansiysis of Variance of the Base Rates}

A visual inspection of Table II indicates that the V-Lo group had an apparently higher base rate than the other groups. To see if this apparent difference reached statistical significance an unequalN's analysis of variance (Winer, 1962, p. 96) for single factor data was performed. The results of that analysis appear in Table III, showIng the $F$ statistic to be much smaller than needed for significance.

The base rates were also examined to determine if the first three days of recording were different from the last three days. This Irfformation was used in deciding if a three-oay or one-week recording period should be used on follow up. A longer recording period might be 


\section{TABTER II}

MEANS AND STANDARD DEVTATIONS OF ALL TREATMENT GROUPS AT BASE RATE AND FOLLOW UP

\begin{tabular}{|c|c|c|c|c|c|c|c|}
\hline & & \multicolumn{2}{|c|}{ Baserate } & \multicolumn{2}{|c|}{ Follow up I } & Follow & Up 2 \\
\hline Crouns & $n$ & $\bar{X}$ & SD & $\bar{X}$ & SD & & SD \\
\hline$D-\mathrm{H} \mathbf{i}$ & $?$ & 26.36 & 9.78 & 20.33 & 15.45 & 23.09 & 15.4 \\
\hline D-Lo & 8 & 25.45 & 6.99 & 18.59 & 16.95 & 19.50 & 16.8 \\
\hline $\mathrm{V}-\mathrm{Hi}$ & 6 & 25.45 & 8.15 & 12.05 & 7.45 & 15.93 & 5.8 \\
\hline V--to & 9 & 33.52 & 10.98 & 12.73 & 13.83 & 15.51 & 13.4 \\
\hline
\end{tabular}


THBLE III

SUMARY TABLE OF ANALYSIS

OF VARIANCI OF BASE RATES

\begin{tabular}{l|c|c|c|c} 
Souree & SS & df & WS & F \\
\hline Treatments & 246.17 & 3 & 82.06 & .92 \\
\hline Error & 2299.59 & 26 & 88.45 & \\
\hline ToThIs & 2545.76 & 29 & &
\end{tabular}


indicated if, for example, there were any shortuterm effects on smoktng rate which spring fron the recording per se. There was no statist.ically significant difference $(\underline{z}=.75)$, and the planned three-day diary-keeping tine was instituted.

\section{Treatment Snoking Rates}

Figure 1 shows the treatment smoking rates of all groups. The figure indcates that the subjects who vere asked to double their smoking did, according to their smoking diaries, doubie; and the subjects who were asked to taper off by the Von Dedenroth method did, again according to their diaries, taper in a predictable fashion. The data for the Von Dedenroth groups, in fact, show drops from the base rate to the start of treatment and at the beginning of the second week of troatment at precisely the times when the subjects were given instructions to curtail their smoking during two and one-half and then rive hours of the day. The data represerting each trestment day are based on varying numbers of subjects because of inconststercies in the reporting of the data. One subject in the V-H1 group, in fact, lost the data for the last two treatment weeks. However, most of the data represent numbers of subjects elther at full strengtin or one less than full strength.

\section{Analysis of Varlance of Final Data}

Figure 2 shows the final data graphed as a mean cigsrettesper-treatment. Figure 3 shows the same data graphed in a grouppercent-of-base-rate format. Both filgures compare base rates versus follow up periods 1 (three to five months after treatment) end 2 (six to eight months arter treatmont). Table IV gives the analyets of 


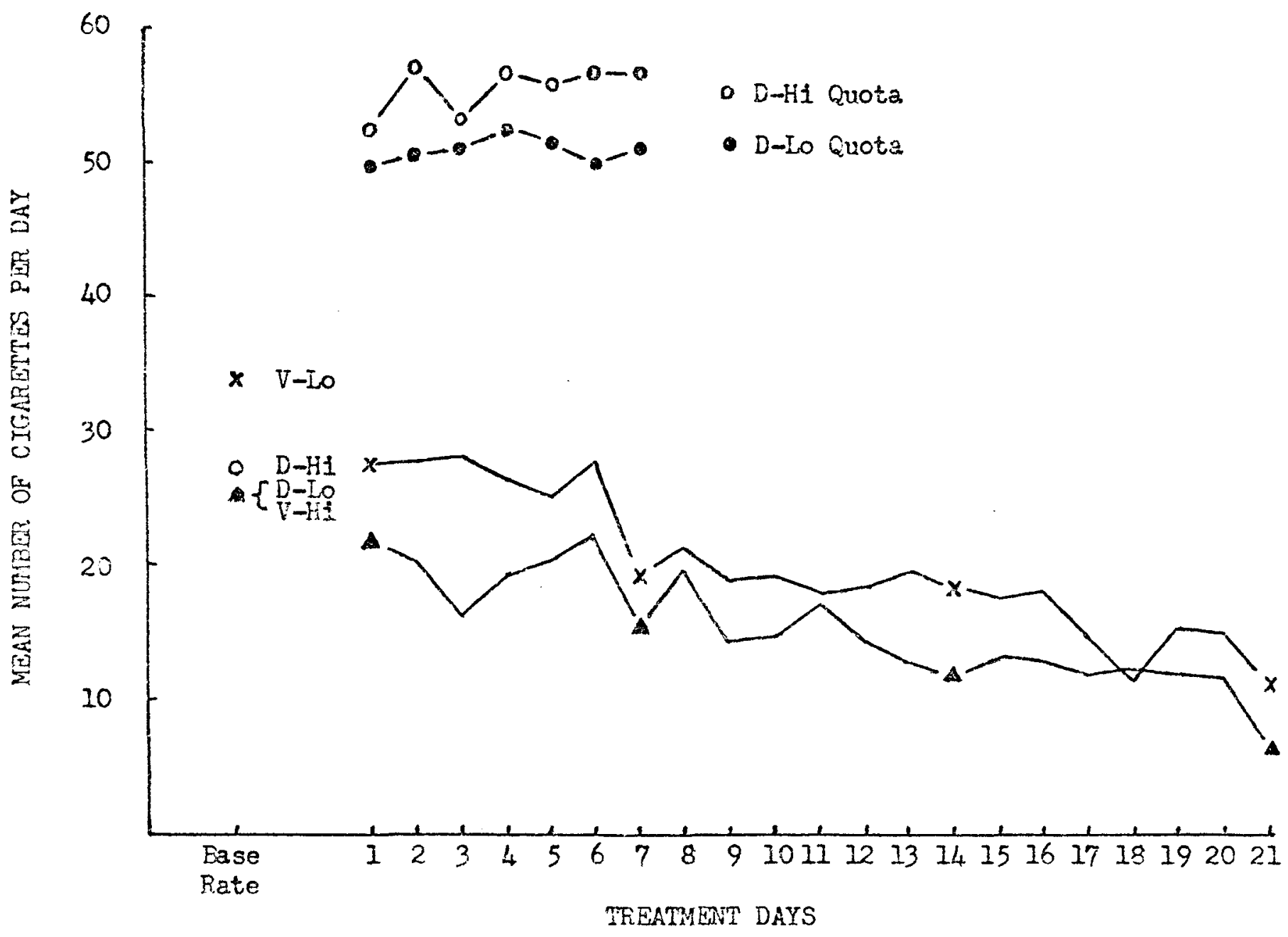

FIGURE 1. Mean Number of Cigarettes Smoked per Subject per Day for each Treatment Group During Treatment Compared tc Base Rates and Quotas. 


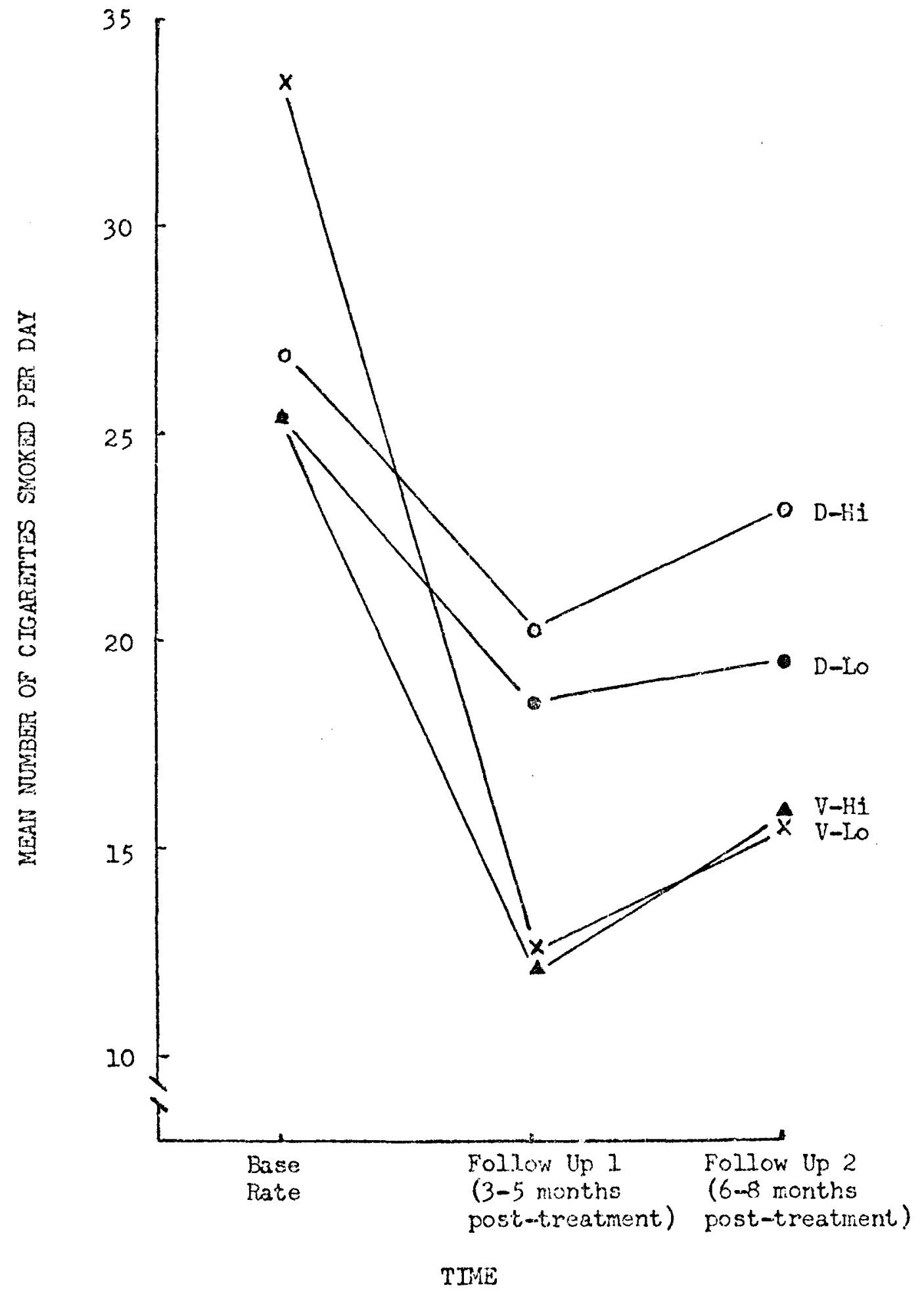

FrCU?E 2. Mean Humber of Cjfarettes Snoked per Day at Ease Rate and Follow ups for each Treatment Group. 


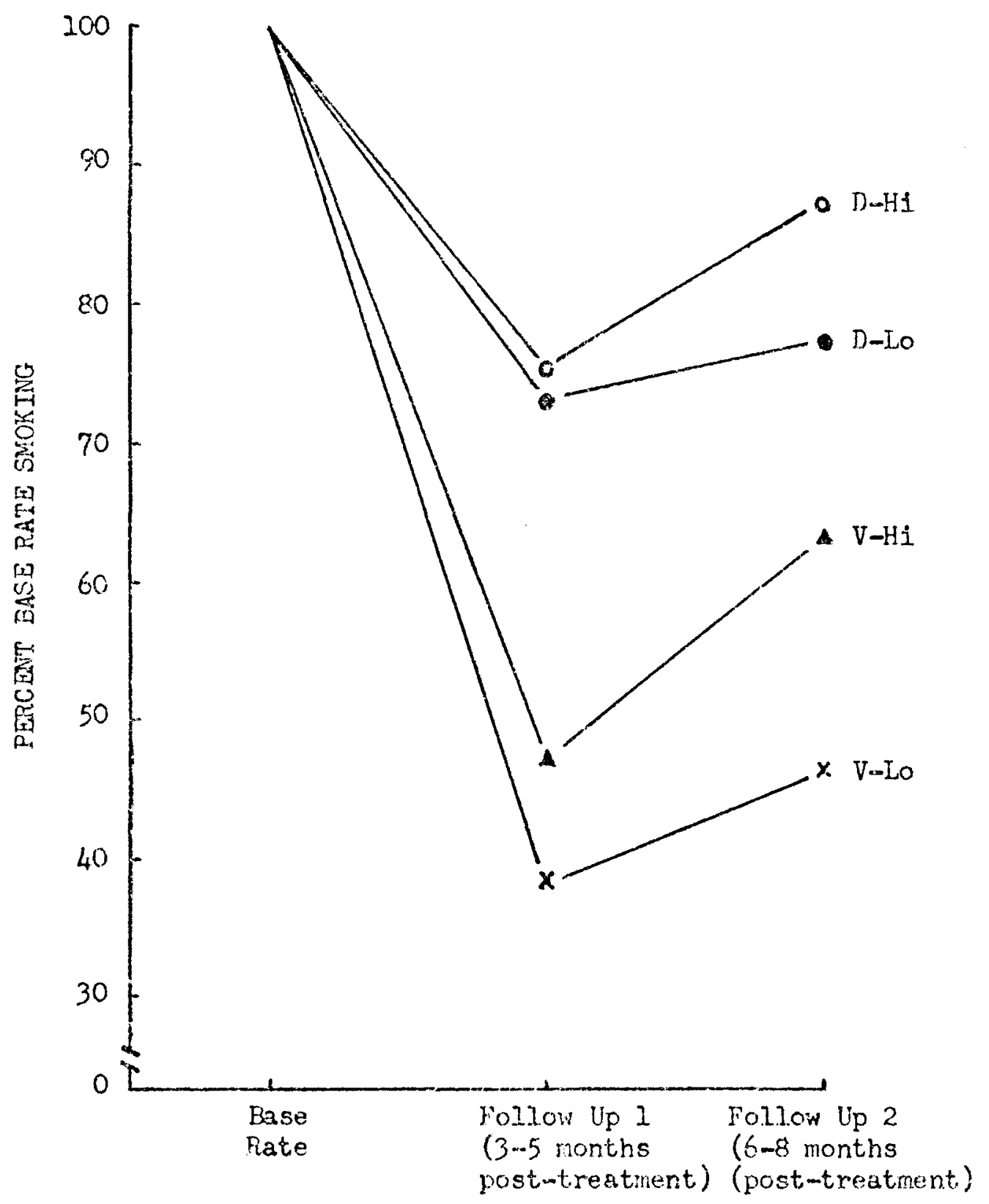

FICURE 3. Group Percent Baso Rate Smoking at Fojlow ipa 
TAEIE TV

SUMARY TABLE OF A 4 EY 3 WNEDUAL N'S RNALYSIS OF VARIANCE

WITH REPEATED MEASURES ON MEAN NUSER OF CIGARETTE

SAOKED PER DAI AI BASE RATE AND FOLLOW UPS

\begin{tabular}{|c|c|c|c|c|}
\hline Source & SS & df & MS & $\mathrm{F}$ \\
\hline Between Subjects & & & & \\
\hline $\begin{array}{l}\text { Trestzents } \\
\text { Subjects within groups }\end{array}$ & $\begin{array}{r}358.76 \\
9757.33\end{array}$ & $\begin{array}{r}3 \\
26\end{array}$ & $\begin{array}{l}119.59 \\
375.2 \varepsilon\end{array}$ & .32 \\
\hline $\begin{array}{l}\text { Witinin Subjects } \\
\text { Time } \\
\text { Tins by treatment } \\
\text {-ine by subjects with treatment }\end{array}$ & $\begin{array}{r}2194.31 \\
531.43 \\
3452.02\end{array}$ & $\begin{array}{r}2 \\
6 \\
52 \\
89\end{array}$ & $\begin{array}{r}1097.16 \\
88.57 \\
13.88\end{array}$ & $\begin{array}{r}73.73^{7} \\
5.95^{1}\end{array}$ \\
\hline
\end{tabular}


variance summary of an uncqual-n's 4 by 3 andyels of variance with repeated measures over one factor (Winer, 1962, p. 374). The analysis of vartance indicates the matn effect for time and the interaction of tine and treatinents achieved statistical significance at the .0I level, while the main effect for treatments falled to achieve statistical significance. The analysis thus implies that all treatments ylelded a diminution of smoking over time, but that some treatments yielded a greater drop in smoking than others.

\section{Analysis by Post Hoc Tests}

Because of their equalizing effect on whatever differences occur at base rate, percent-base-rate data have many advantages for post hoc analysis. This remains true despite the analysis of variance of the base rates which showed no signiflcant difserence between the base rates. In many senses, a ciearer picture of the data are obtained whenever the differences, however small, are rulled out at the onset. However, when one divides the group totals or means at follow up by the totals or means at base rate, one has no method of obtaining standard deviations and thus cannot perform the usual statistical analyses. Therefore, analyses of post hoc data will be on the untransformed data and on a percent-base-rate measure which will be explained below. Unequal-N's $\underline{t}$ tests were perrormed on the untransformed means of the following groups at the first follow up point: V-H1 versus $D-L o, V-L o$ versus $D-I o$, and $V$-Io versus $D-H i$. The results $(t=3.36$, $\mathrm{d} f=12 ; t=3.08, \mathrm{~d} f=15 ; t=3.68, \mathrm{~d} f=14$ respectively) indicate both doubling groups difiered signtfifantly from both Von Dedenroth groups at the $p<.01$ level (two talled). No analyses were performed 
comparing the means of the two Von Dedenroth groups or the two doubling groups because the apparent differences were so small. Four comparisons (V-Hi versus $\mathrm{D}-\mathrm{LO}, \mathrm{V}-\mathrm{H} i$ versus $\mathrm{D}-\mathrm{H} i, \mathrm{~V}-\mathrm{Io}$ versus $\mathrm{D}-\mathrm{H} i$, and $\mathrm{D}-\mathrm{H} i$ versus D-Lo) were made of the Follow Up 2 data using an unequal-N's $\underline{t}$ test as before. Only one of these, the $\mathrm{V}-\mathrm{HI}$ versus $\mathrm{D}-\mathrm{H} 1$ comparison of group means, yielded statistically significant results $(t=3.57, \mathrm{~d} f=$ $11, \mathrm{p}<.01$, two tailed). Although the mean value for the $\nabla$-lo group was slightly lower than the $\mathrm{V}-\mathrm{HI}$ group, the V-Io versus $\mathrm{D}-\mathrm{Hi}$ comparison failed to achieve significance because of the larger standard deviation of the V-Io than V-HI group.

The percent-base-rate comparisons are more difficult. One can arrive at percent-base-rate data by means other than those outlined above. One can compare each individual subject's base rate with his follow up rate and thus take means, standard deviations and, ultimately: t's on these data. However, as a comparison of Figure 3 and 4 wili conflrm, the means thus obtained are not equal to those calculated by tot-aling each group's base rates and dividing by the tctal of the group under question at the appropriate follow up. This is perhaps more readily seen in mathematical form:

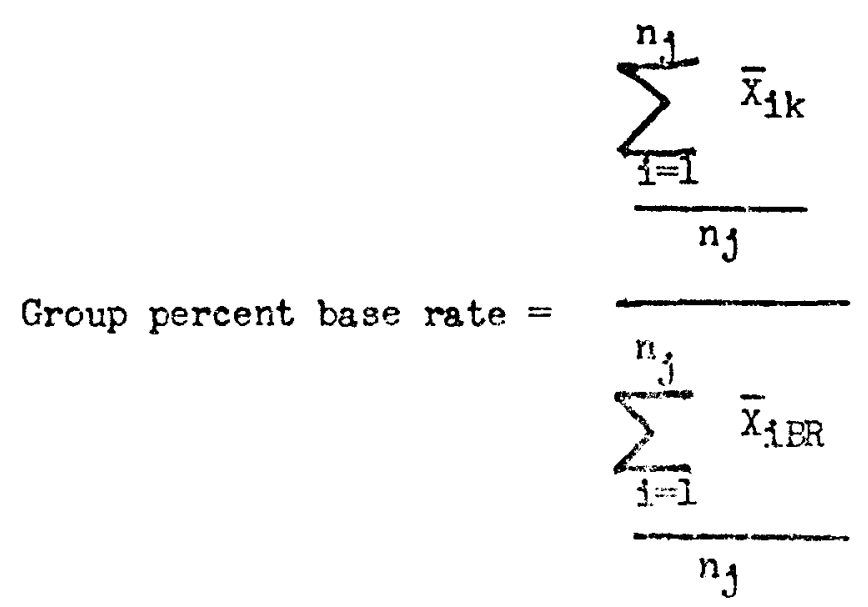




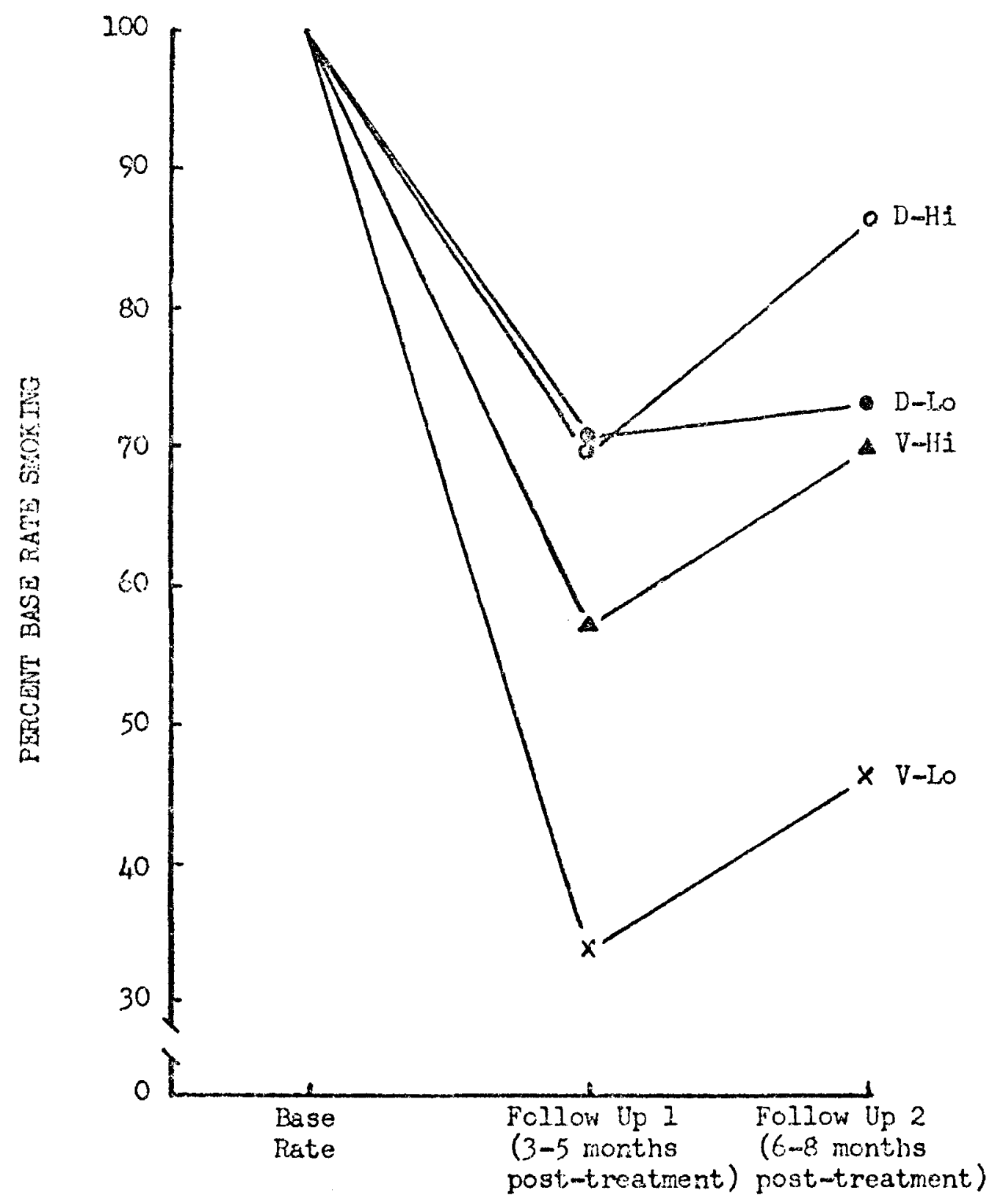

FIGULE 4. Mean Individual Percent Base Rate Smokjng at Follow Ups. 
and individual percent base rate $=\frac{\sum_{i=1}^{n_{j}}\left(\frac{\bar{x}_{i k}}{\bar{x}_{i B R}}\right)}{n_{j}}$

Where: $\overline{\mathrm{X}}_{i k}=$ Nean number of cigarettes smoked per day by subject 1 In follow up $k$,

$\mathrm{n}_{\mathfrak{j}}=$ Number of subjects in group $\mathfrak{f}$,

$\bar{X}_{1 E R}=$ Mean nunber of cigarettes smoked per day at base rate by subject 1 .

It is intuitively obvious that:
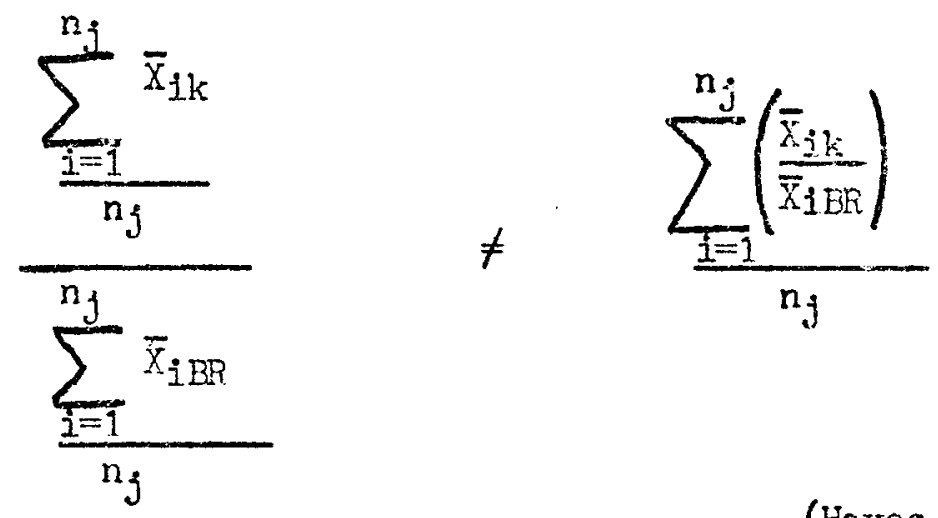

The data thus transformed have another pecullarity: the absolute levejs of the base rates are ignored. For example, a subject who drops from 20 to ten cigerettes per day is seen as equivalent to one who drops from 50 to 25 cigarettes per day. Both have percent base rates of $50 \%$. Nevertheless, this individual trangformation does give some Insight as to group scores with a.l Initial variation nulied out.

An unequal $-N^{\prime} \cdot \mathrm{t}$ test of the first follow up showed the $V$-Lo versus D-Hi comparison approached a statistically significent level $(t=1.89, \mathrm{df}=14, .05<p<.10$, two taliled $)$. The most extreme 
means (Vio versus $D-10$ ) did not approach sfgnificance $(t=1.48$, df $=$ 15, two tailed) apparently because of the much larger variance of the V-Lo group. A similar unequal-li's te test on the last follow up yielded a $t$ value of $2.14(\mathrm{~d} f=14)$, which closely epproached significance on a two tailed test $(.10>p>.05)$.

Taker as a whole, the results at the last follow up (the follow up of most interest) indicate that only the most extreme values differea.

\section{Analysis of Raw Data}

The raw data (Appendix XIV) yleld three noteworthy features. One is that despite the significant interaction of treatments with time noted above, when the data are examfned for percent abstinence, there are no apparent differences between the Von Dedenroth groups and the doubling groups. The number of quitters at Follow Up 1 for the doubIng groups was three and for the Von Dedenroth groups was four. At Follow up 2 there were again three quitters (although one was different than before) in the doubling groups but only two in the Von Dedenroth groups. Also, examination of the raw data shows that at Follow Up 2 orly one Von Dedenroth subject was smoking a.t more than his base rate, while seven of the 15 doubling subjects were smoking more than their base rate. The treatment by time interaction noted in the analysis of varionce must, therefore, be due to the larger numbers of subjects in the Von Dedenroth groups who were able to cut down the ir smoking without becoming gbstinent. This finding is dissonant with lichtenstein's (1571) assertion that subjects who do not quit are very likely to return to their pre-treatinent rate. One assumes here that the six- to elght- 
month follow up in the present study was more than adequate for most smokers to bounce back to base rate (Funt, et al., 1971).

Another finding of note is thet the percent abstinence rate of $23 \%$ for the flrst follow up and $17 \%$ for the second follow up (taken across all groups) is in the general range noted in the literature search (Hunit, et al., 1971).

\section{Questionaire Data}

The questionnaires for Follow Up 1 (see Appendix VI) and Follow Up 2 (see Appendix VII) differed only in that Question 5 contained an edditional. Foll in Follow Up 2 allowing the subject to report that he quit smoking for more than four months. The results of Question 1 of Follow Up $I$ are seen in Table $V$ and the results of Question $I$ of Follow Up 2 are seen in Table VI. Responses to Item I-I are listed in AppendSces IX and $X$ for Fcllow Ups $I$ and 2 , respectively. In both cases the majority of responses were for the phrases indicating the subject was "smoking the same as before the project" or "quit after the program, but started moking again and still do." Thus, for most people the program generally had temporary, if any, effect in the1r eyes. Only two people reported they had been totally abstinent throughout the follow up perLod $(7 \%)$. This finding further emphasizes the effect of the procedures on the reduction of smokling as cpposed to the elimination of smoking.

Question 2 of the questionnaire ylelded $23 \%$ and $17 \%$ of the subjects fcr Follow Ups $I$ and 2, respectively, who had been totally abstinent for the past week. One subject included in the above tally reported total absifinence in a telephone contact, but returned no questionnafre. Thege flgures, with the addition of the subject whose abstinence report 
TABLE V

RESPONSES TO TTEL 1 OF FOILOW UT QUESTIONNAIRE I:

"HOW WOULD YOU DESCEIBE YOUR SROKING PATTERN

SINCE THE SNOKMIG FEQTECT?"

Fo11

Number

A. Quit and haven't smoked sinee

3

B. Fiad a few clgarettes (less than one pack total)

0

c. On and off smoking

3

D. Smoking less than before the project

E. Smoking the same as before the project

F. Snoking more than before the project

G. Smoked a littie after the program, out quit and haven't smoked since

H. Quit after the program, but started smoking again and still do

I. Other pattern (please describe) TOTAL

1 Total is greater than the number of subjects ( 30 ) becauss some subjects chose more than 1 descriptive phrase. 


\section{TABLE VI}

RESPONSES TO ITUI I OF FOIJOW UP QUESTIONAIRE 2:

"HO: WOULD YOU DESCRIBE YOUR SHOK IIG PATTERN

SIIVE THE SIYOKUIG PROJECT?"

Eoil

Number

A. Quit, and haven't smoked since

2

B. Hiad a few cigarettes (less than one pack total)

0

C. On and off stroking

2

D. Sinoking less than before the project

8

E. Snoking the same as before the prosect

F. Smoking more than before the project

G. Snoked a Iittle after the program, but quit and haven't smoked since

H. Quit after the program, but started smoking again and still do

I. Other pattern (please describe) TOTAL

1 Some subjects chose more than 1 descriptive phrase. 
was by telephone, completely colncicie with the data on abstinence obtained from the smoking diaries.

The responses to Items 3 and 4 of Follow Up $I$ can be found in Appendices XI and XII respectively. The responses to Items 3 and 4 of Follow Up 2 can be found in Apperdjces XV and XVI respectively. In general, for Item 3 on both Follow Ups the doubiers tended to pra1se the diaries and the group interaction clmost equaliy to the exciusion of othel points in the program. In regards to Itern $4_{4}$, which asked about the least useful aspects of the program, there was a general dearth of responding in the doubling groups. The predominant response was that nothing was undestrable about the program. The uther responses tended to scaiter over practically all other elements of the program. The Von Dedenroth groups likewise responded that on the whole there was very Ifttle wrong with the program and what they did find wrong with the program was scattered over many different areas with no area being a specLal favorite. Examples of these complaints among the doublers were: they did not have sufficient will-power, the deposit was of no help, the diarles were of no help, group interaction was of no help, and the follow ups were insufficient. The Von Dedenroth groups complained of such things as switching brands, their own lack of will-power, the deposits, having to write reasons why they should quit, the tapering procedure Itself, and the group interaction.

Subjects' estimates of how long they had been off clgarettes since the end of the treatment (Item 5 of Follow Up 2) may be obtained from Table VII. The data show a relatively even scatter of cholces over nine foils with the average subject picking the middle foll-n three weeks. Only one-sixth of the subjects report they were unable to 


\section{TABLE VII}

RESPONSES TO ITEM 5 OF FOLLOW UP QUESTTONNATRE 2:

"WHAT IS THE LONGEST PERTOD YOU HAVE BEEN OFF

CIGARETTES SINCE THE END OF THE PROGRAM?"

\begin{tabular}{l|c}
\hline Aoll & Number \\
\hline B. Nore than four months & 2 \\
\hline C. Nore than two months & 1 \\
\hline D. One month & 4 \\
\hline E. Three weeks & 5 \\
\hline F. Two weeks & 3 \\
\hline G. One week & 2 \\
\hline H. Less than one week & 3 \\
\hline I. Never quit & 3 \\
\hline
\end{tabular}

1 One subject eircied both $D$ and $E$. A coin flip determined which foil was credited-D roll.

2 One subject left this question blank and one subject did not return a guestionaire for this follow up. 
quit at a?l, but only seven of 30 had periods of longer than a month of total abstinence.

Appendix XVII makes avaliable the advice given the experimenter on Follow Up 2, Item 6. Appendix XIII makes available the advice given the experinenter on Follow Up 1, Item 6. These are heterogeneous and difficult to sumarize, but some patterns do stand out. Many subject.s wished for booster meetings after the end of treatment. Iri fact, allt of the groups asked for something of this nature on the last treatment day. One group (D-Lo) actually did meet as a kind of "smokers anonymous" for oves a morth following treatment. Other responses to this Item suggested that the group spirit had been helpful. Several consoled the experimenter for their inability to quit and pointedily assumed responsibslity for their failure.

\section{Observationai Results}

The study resulted in many inceresting observations that were not amenable to quantification. The doubling condition was an ordeal. In fact, that was a term whtch some of the subjects used to describe it (see hppendjces I \& XIII). After the first day of doubling many of the Iightex smokers became nauseous. Several reported they had to lie down after dinner to avold vomiting. One woman was not so lucky and quite literally losi her lunch one afternoon. The heavier smokers complained of headaches. In a few days these symptoms abated and g grey dullness set in. The doubling group who looked outgoing and spontaneous in the pre-treatment meetings began to look grey, drawn and lathargic. They eat silently around tho table looking at thejr watches and lighting their one-clgarette-pex-X-number-of-utrutes. (Nost of the doublers had 
to rigidly keep to a schedule of one-cigrette-per-X-minutes to meet thelr quotas). They talked aoout thoir physical symptoms: headache, nausea, dizziness, Insomnia, raw tongue, ete. Two male subjects spontaneousiy reported episodes of impotence. In the words of one of then, "This project has ruined sex 11 fe. And it's rot because I'm not trying!"

Other than the doubling groups there were few dramatic observations to be made. All of the groups, with the exception of the V-HI group, developed a decided "group spirit". The standard bit of advice offered the experimenter was that the groups should continue into the follow up periods. Ore group (D-LO), as mentioned before, continued to meet of its own accord after the treatment was over.

The group which provided the greatest anount of trouble was the $\mathrm{V}-\mathrm{Hi}$ group. They were rather argumentaitye with one another. Some of them missed some sessions, thus necessitating individual arrangements. They were often tardy in returning thejr diaries. One subject, in fact, never returned the last two weeks of the treatment diaries. 


\section{DTSEUSSION}

There was no apparent effect for high versua low interference. Those subjects who were instructed to apply the procedures during times when they normally would smoke cut back on smuking no better than those who vere asked to apply them during low smokjng tines. Indeed, a casusi Inopection of the percent-base-rate grephs (Figures 3 \& 4) might lead one to the opposite conclusion.

What then of the signiftcent time by treatnent difference? Here the vartous veys of amalyzing the data a posteriont corapllcate the picture. The results vary depending on whether ove is ving the untransformed dats or the Individuel-percent-bese-rate dats. Using the uniransformed mean-number-of-cigarettes-smoked-per-dat dstu one obtalng a clean segaration between the doubling ard Von Dedenroth groups at FolIow Up 1. The individual-percent-base-gate data show only nearly signIficant difierences of extrene groups on Follow Ups 1 and 2 . By the second follow up, post hoc analysis of the untransformed data show the V-Hi group continued to differ from the D-HA group. The transformed data again showed nearly signiflcant differences of the extreme groups only. Given the small numbers of subjects in this study, it may be sald that a differential treatinent effect has been unearthed.

What then is the nature of the ifferential treatment effect? The high versus low interference condition was the only planned treatrent dffference within the doubling and Von Dedenroth groups. Other than this manfpulation, the groups were treated so much alike as the experimenter could manage. However, the basis upon whtch this inter- 
ference separation was built was very shaky fron the onset, as it was extremely difficult to find tines or situations during which the subjects did not smoke. If this difficulty were as great as the experimenter perceived it, and if this misnipulation were the only systematic difference within the groups, then there is no possibility of a difference between high and low interference conditions of each treatment. If, per chance, the experinenter had greater succese than he suspects in finding times when the snokers habitually did not smoke, even then there would have been Ifttle effect in the doubling groups. In the doubling ireatments it was such a strain for subjects to meet their quota of double smoking each doy, that, for the heavier smokers In each group, it was simply not possible to concentrate on specific periods or situations at the expense of the rest. They were chain smoking from the minute they got up to the time they collapsed gasping in bed.

For the Vor Dedenroth treatments it is conceivable that for the first treatment week the iive one-half hour interruptions of the smokers routine could be targeted rather specifically to smoking or no smoking pexiods in the subject's nomal pattern. With the no smoking times Increased to one hour each, was the case for the last two treatment weeks, it becomes more difficult to separate the high interference from the low interference conditions. Thus, even if the separation between high and low smoking times were successfully made, the effect such a separation would have on the Von Dedenroth groups would have to be resultant mainly from the first week's treatment. Mlso, not only would one have to account for an interference efiect resultant from only onethisd of the treatment, but one would have to account for an effect in 
the direction oppostte to that predicted.

For these rasons it is argued that the observed effect was a difference between the doubling and Von Dedenroth groups which is somew whet befogged by the small number of subjects.

One veriable on which this study may be compared with those which came before is the variable of frecent-base-rate-on-follow-up. If one refers to the preceding literature review one will note that the percent base rate herein obtained for the Von Dedenroth groups was, on the whole, equivalent or superior to, those obtatned in previous studLes (Koenig \& Kasters, 1965; Steffy, et al., 1970; and Sipich, et al., 1974). Thus, the results for the Von Dederroth groups in this dissertsa tion may be viewed as rather promising in itght of the previous research. As noted in the results section, It is unusual. to nave a treatment which resulted in a long term dininution of sinoking rate. The ustal finding in the literature (as reviewed by Lichtenstein, 1971) is that the percent base rate figures are heavily influenced by the number of subjects who have quit entirely. Here too this study appears to differ from those which have come before. The Von Dedenroth groups showed a sustained drop in snoking without showing any more abstinence than the doubling groups. An explanation of these results may be had from the nature of the treatment 1tself. To wit, the Von Dedenroth subjects were forced to examine their smokirg through an extensive diary keeping procedure and were thus able to gain a constderable degree of awareness of a habit which most reported as autcinatic. In addition, the subfects were provided with mary alternatives to smoking. Thus both Von Dedenroth groups nixy have gained awareness of the pecullar stinuld which triggered their own smoking and were able to substitute 


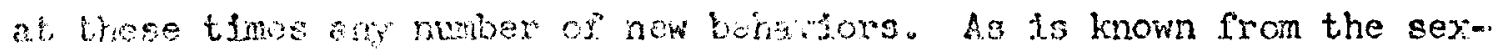
W. deviation Itwrature (Freonrn, 1972), it Is very dificult to elin-

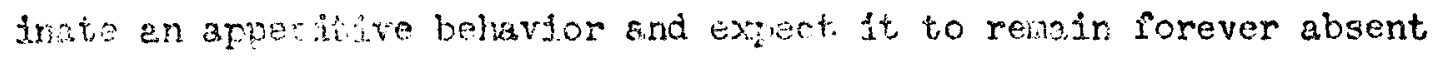
without aubstituting another behavior for it. Thus, one of the valuabie "bseanonts" provided in the Von Dedenroth groups may have been the substitutions mith were araflable to the subject.

Thetevor else may be said about these pesults they are most

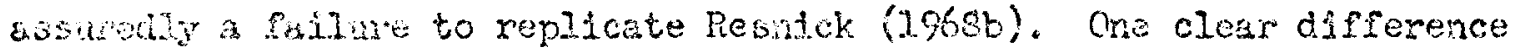
botwes thio work sid the epparontly sucoessid sncreased moking studion (Wesnith, 3968 s b; Schahl, ot al., 1972) is that the present sanphe was dram frota nowstubent populetion. There was only one full-

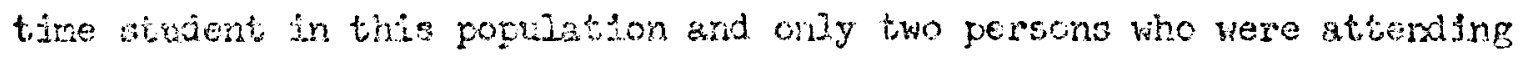
colsege at the the of the stury. The abjects for this discertation conatsted lewgity of midd? busthesenen on seif memployed ronen.

It my be thet one of the phononena observed in boh the Schm

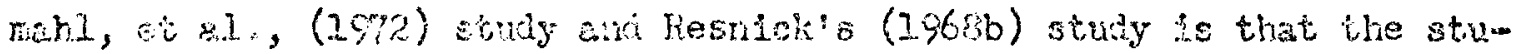
dents oblatred as subjesto were ando thet the experinenters were pro-

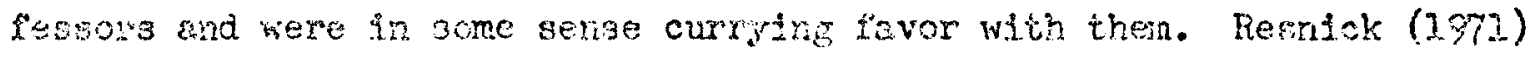
tpeoficenly donied that bis subjects vere dram from his classes, but this coes not rule out the posaiblitty that the siudents thourti they mlents bite hic elasses some day. Surely this varluble is nos operative in tho present study.

The method of recutument was a good deal iffierent in this stwdy also. Tre prevous troreased choking etudies, cham fron student

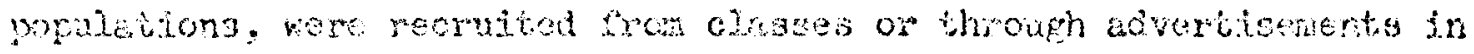

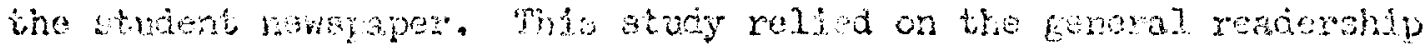


and viewship of the newspaper and broadcast media.

Another difference in the populations of the present study and the previous increased smoking studies was that this population, being older, had a more lengthy smoling history than the student samples. Thus, the smoking habits of the subjects in this study were more deeply ingrained than in the studies using students as subjects. It might be that the works of Resnick and Schmahl, et al., are specilically targeted to student populations with their short experience with smoking. Thus, smoking experience, or at least subject variables generally, may be very inportant in the doubling treatment. It may be interesting to note that of the two doubling subjects who were able to remain totally absitnent from the end of treatment one was the yourgest subject and the only full-tine student in the study.

These results may also be viewed as a failure to completeif replicate Von Dedenroth (I964a \& b). Although these results appear to be more encouraging for the Von Dedenroth treatment than for the doubIing treatment, this study surely did rot obtain the fabulously high success rate reported by Von Dedenroth. A large difference between the present study and 1ts parent work, however, can be rather clearly spec1fied. Von Dedenroth viewed his treatinent as a hypnotic treatment and Induced irance states in all of the instruction periods. Thus, a factor missing in these treatments that was present in Von Dedenroth's origina.I works was the hypnosia. Clearly if one wishes completely to replicate Von Dedenroth, hypnosis would have to be used.

The gentle reader may remember that in the andysis of the literature seamch the author fejt this difference to be small. However, Es the saying implies, the difference between mourtains and molentils 
is one of perspective. From this vantage point hypnosis looms rather larger on the horizon of research.

Why then was the Von Dedenroth treatment apparently superior to \& doubling treatinent? A possible answer may be found in the subjects comnon observation that they foumd their habit to be automatic and unthinking, and that the diaries helped to make them aware of their automatic habit. The subjects in the Von Dedemroth treatment had more time to utilize the smoking diaries than the doubling treatment. In the doubling treatments the smoker was able to observe his habits undisturbed only in the one-week base rate period. In the Von Dedenroth treatments each snoker had, in addition to the base rate period, three more weeks of observation of his habit at some level of intensity. The first of these three weeks interrupted the subjects' smoking for only two and onemalf hours per day and the latter two weeks interrupted the subjecis' smoking for a maximum of five hours each day.

It is felt this more intense observation of the smokers habits plus the substitutions which wre avaliable may accourit for the possible treatment affect. To restate a point, these substitutions, as is known from the sexual conditioning Iiterature, (Freeman, 1972) are frultful when dealing with appetitive behaviors. Thus, if one eliminates an appetitive behavior without substituting in its place some other behavfor the subject is likely to go back to the undesirable appetative behavior. The substitutions in the Von Dedenroth treatment provided the subjects with sanething else to do instead of snoking. In summary, the Von Dedenroth subject 3 were able to observe their smolring habit for a longer period of tine than the doubling subjects. They were then able to insert the varlou's substituie behaviors which were suggested to them 
when patterns in their smoking hehavior were observed.

What of the generalfty of these results? What factors in this study are there that would point to the use of these techniques with what groups? When the subjects of this study were compared with the non-stbjects who responded to the publisfigr, went to the inftial meetfige, and filled out the Personal Data Cards, it will be remembered that the non-subjects tended to be the poorer rdsks. They had begun to smoke earlser and tried to quit more often with less success. Thus, it might be said that the population used in this study was of higkily motivated volunteers who were likely candilates for success. This, however, is no particular drawback for generality, for unless one is seeking coercive treatments which can be applied to pocrly motivated non-volusteers, this is the population with which the practicing clinician would be dealing.

What of the other subject variables such as the resemblence of this population to the sorts of people tovard whom a smoking treatment would comitnonly be aimed? Here one finds a major virtue of this dissertation. This study dealt with a group of suibjects who more closely resemble people-1n-general than those smoking studies whtch rely upon that white rat of clinical psychology, the college sophomore. The businessmen, housewives, CPA's, insurance salesmen, secretaries, nurses, construction workers, dentists, and school teachers who made up the subjects of this study provided a far more diverse group th age, education and soctal slase than college students, and may thus be more represencative of people--tn-general than a college population.

Future research my be pointed in two directions by this dissertation. The first direction, as meritioned becore, is the explora- 
tion of hypnosis in the Von Dedenroth trestment. This dissertation asgerto that the Von Dedenroth treatment may have promise. If a careful test of the full treatment, including hypnosis, shows any Increase in tho effectiveness of this already successful treatment, then this resuli may lead to theoretical insights beyond its obvious practical iruport.

The other direction toward which this research points is a further explcration of the interference variable. For reasons cxplained above, this dissertation did not adequately explore the vartable of interference with the smoking habit. It awaits some new vehicie or more resourceful explorer before its function in smoking can be cleared up. 
APFENDIX I

NEWSPAPE PUBLICIIY OF THE EXPLR IMENT 
Wecinesday. March $6,1974^{\circ}$

THE WICHITA EACLE $\therefore$ Page 5

-

"

By JANE FIOERCHINGEiR - Salk explained in an inter-

$\begin{array}{cl}\text { Staff Writer } & \text { vicw that he will be testing } \\ \text { Need help to gut smoking? two mothods of helping people }\end{array}$

Need help to quit smoking? two mothods of helping people

Well, you're necced too. quit smolsing - the only two

moinods of ricking the habit he adds. part of Sal's inter. group will neet hricfly each

. Weekday right during the

Whita - provided the approaches seem to work. grolips will spend about rescarcher comes up with His plan is to divide the week gathering data about sujoctis.

participants randomiy into their personal smokir Fack-a-day smokers or two groups. The linst will be habits

beter ate neeried - 80 of asked to double thoir nomal The initial neeting will be at then. Aid to assure that the rate of smoking for one week, 6:30 p.m. Niarch 12 ir the iA wouidhe non-smokers are then guit. Auditorium. Interested pe* acocuatcy motivated, each Totally? "Forever and sors are asked io call the VA vil be rccuired to put up a ever," he assures. psychology department in ad

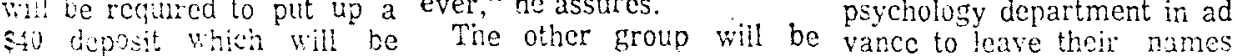
retuned in thres installments asted to gradually change All participants are required as each project requiiement their smoking habits; at the to have their physicians' okay is completed. same time decreasing to participate.

Take courage though. That consumption. For instance, he Salk said both approaches dos mot me ones his illustrated, if a person have met with relative money if he fails to join the smokes as soon as he success in previous research ranks of the wead free.

awakens in the morning, his success in previous research

But firi, meet rescarcher starting assignment might be

Other people have gotten Gary Sali. Salk is working on to have a glasss of orange as high as a 60 per cent his loctorate in psychology at juice, savoring its taste and success rate with the double the University of Louisville toel in his mouth before he smoking approach The other

(Ky) His project is being smokes.

conducted under the auspices The demands get tougher of Wichitas Veterans with time.

Administration Center, where

he is interning this year. moking anproach the othe is not quite so clear. but probabiy better than chance,"
he said, explaining tilat the chance rate runs only about 20 per cert:.

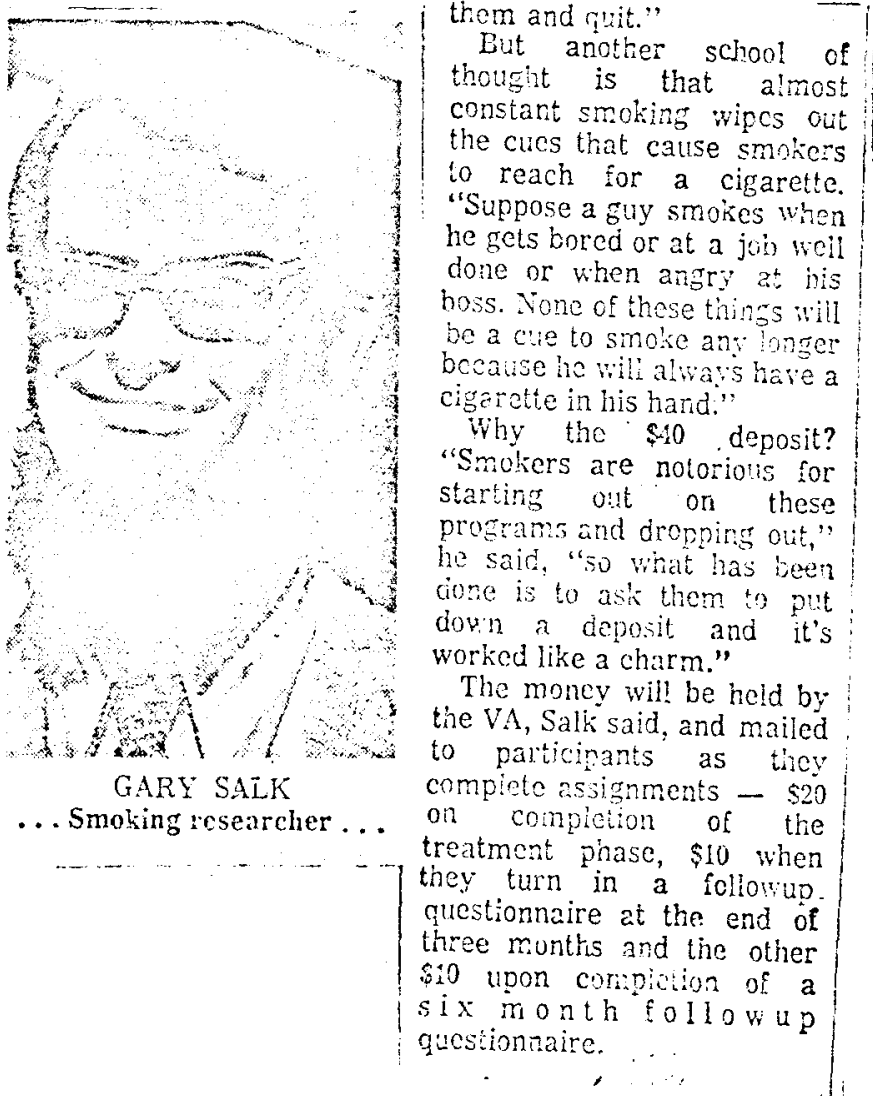

One theory behind the couble smoking anproach is that the person mares himself sict of it. "The gtty who orixirated do it smoking went from one to "ive packs a any," Salk said "At the end of a woek he couldn't stand the sight of id, meetings will be cheduled on four consecutiv 

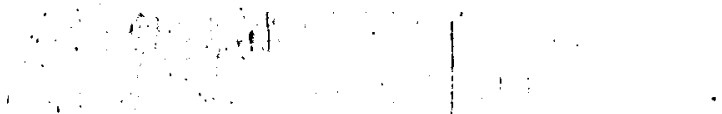

Tueaday, March 12, 1974 Page 7A

\section{Volunieers} Needed Now For Project

Forly more volunteers are needed for a cigaret smoking research projeci hore, accotiing to Gary Salk, a psychology researcher at the University of Louisvilie (Ky.).

Smokers who want to kick 1. the habit will gather at 6:30 - tonight in $t \mathrm{~h}$ e Veterans Administralion Auditorium to participate in the research program.

The project will require 80 volunteer smokers who will be asked to deposit $\$ 40$ each with the VA. The moncy will be re-

- turned at intervals as research. continues.

- The project will divide smo- kers inte two groups. One - group will double cigarctte

;. consumption then quit "cold turkey" while the other group will taper off. These are two methods which jave worked best in the past, Salk said. He hopes to find ont why. Snokcrs with snoking related discases will be asked to have their physician's approval for the research project. 
The Wichita Beacon, April 1, 1974, Page 1

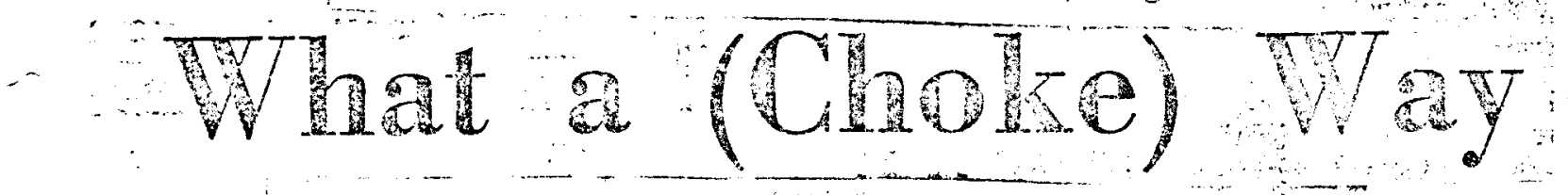

\section{(Choke) to Quir}

$\therefore$ Staff writer Bob Heaton is smoking morc and enjoying it less as he takes part in research to help smokers hick the habil.

\section{By BOB HEATON}

Stafí Writer

Once upon a time, fellows in breechcioths performed a solemn ceremoiny in which fumcs from smoldering plant ieaves were drawn smoidering plant leaves were drawn into the lungs. It

Then a tourist named Raliegh dropped by the village, traded a consignment of beads for a boatload of cercmonial learcs and loft to set up a pipe shop in London.

Things haven't been the same since.

Smoking has gone steadily downhill.

Oree Sir Walter had addicicd a few Londoners to his smoldering plant Lonves, the magic cied away.

Smnking has been taxed, lambasted computerized, in corpor a ted and mechanized.

Snokers have been bombarded with ugly names, such as "air polluter," "cigarette fiend" and worse. They have been relecrated to the back of the airplane, train and bus.
But things may be looking up.

"Operation Oversmoke" opened Wednesday.

It is part of a project being conducter: by Gary Solk, a psychology rescarcher from the University of Louisvilic (Ky) in coopcration with the voterans Administration

Salk is investigating cigarcte addiction and why some techniques for kicking the habit work tetter than others.

He has divided about 30 volunteers into "oversmoke" a nd . "undorsmoke" groups.

Undersmokers are using a technique which involves tapering off their habitis. Oversmokers wili double cigaretto consumption for seven days, then quit "cold turkey."

"The oversmoke technique zeros in on "cucs" which trigger the light-up response. It is a therapy designed to "shotrun" away the effectivity of the cue or habit.

$\therefore$ For example, a volunteer who lights up a cigarette when he awakens in the morning is assigned the iash of chain-smoking eight cigarettes within 45 minutes alter waking up in the morning. That is difficult. one sino smoks after meals is assigned the tack of chain-smoking eight cizareties zitor cach meai of the day.

Coming in on top of the eight walieup cignestes, tho thera ry begins to cryatalize By the end of the seventh, smoke has revarted to fumes, unpicasant oncs.

By the end of the eighth cigartte after lunch of the first day, smoking has already become a tircsome chore. And with $6 \%$ days to 50 , the volunteer begins to sce winy going "cold turkey" might not be so bad after all.

The picture of John Wayne lirgting up on the range loses sone of its iuster.

The Marlboro man nauseates.

Winston doesn't taste so sood.

$\therefore$ You try not to think about what

happens to hams in smokehouses.

By mid-afternoon with only 35 of the assigned 65 coffin nais spiked away, the task seems endless.

The six in the oversmoke group consists of three females and tiree maies, all married.

Doubie-smoking means less than a pack a day for one volunteer. He quit for inore thar two years once, he said. This comment brought a few stares. He 
Ihe "ichita' Beacon, April 1, 1974, Page 1 (continued)

added, "But I" wanted a cigarette the "Mine is set at es per day... which is a whole timc." lot.

1 For one woman in the group. Meetinists are set for double-smokers double-smoking mrans consumption of each night at the $V$ cterans Be cigarelles each day for seven days. : '

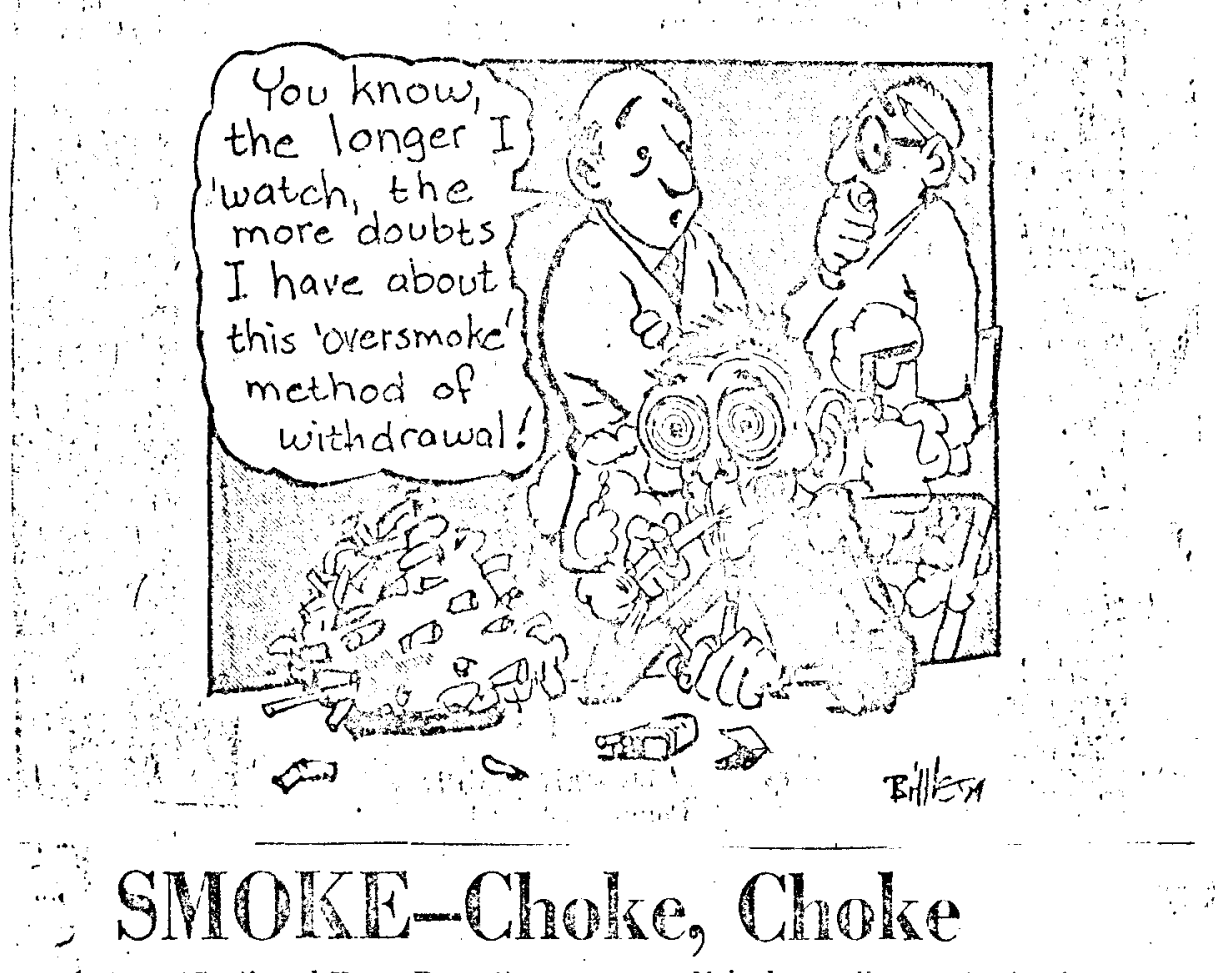

$\therefore \quad$ (Continued From Page 1)

Aindministration for five consecutive

".s. wockday nights. They are to clieck progiess, Salk said.

-... They are also to lend moral support for puffed-out oversmokers. After smoking more or less sicadily

$\because$ for nore than 20 rears everywhere $\therefore$ except in church. the idea of kicking the a.thabit is interesting.

$\checkmark \quad$ Salk stresses motivalion as a critical - factor.

$\therefore+4$ Of course, everyone has seen the stuff put out by the Amcrican Cancer Society. It deais with lungs. It is something like $\therefore$ the movies shown recruits by the Amy in years gone by, to warn them about $\{$ evil women,
Nobody really wants to become a one-lung basket case. Motivation is no problem. 


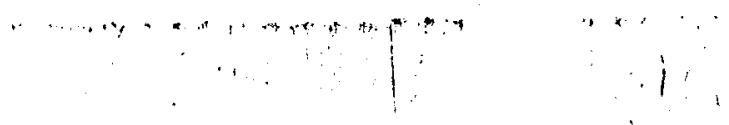

Tuesday, April 2, 1974 THE WICHITA EACLE Poge 8A

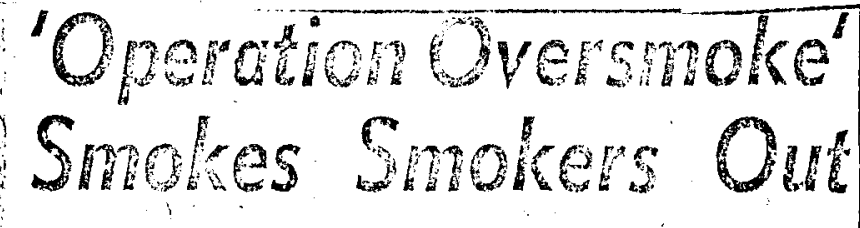

By BOB HEATON Stalf Witer

Like any smoker of more than 20 years standing, I have regalded the possibility of

- kicking the habit in the same light as rumning the Sour-minulo mile pushing a

"Wheelbarrow.

However, there is hope.

"Operation Oversmoke" has been underway for the past five and one-lialf days. It is a simpie program. designed to make nonsmokers out of nicotine fiends.

The research program is

being conducted by Gary Salk, a psychology lescarcher from the University of Lonisville $(\mathrm{Ky}$, ) with the compration of the Veterans Adininistration.

The program soll $\mathrm{nds}$ terribly simple - you smoke yourself hall to death for a weck and then quil -. cold turkey.

Docsn't sound rcasonabie, does it?

Well, one of lhese days, try doubling you cigarctio consumption. Every day. For a week. Zero in on limes when you most enjoy smoking, like after meals and 1 when you "Wake up in the reriods. Chain-smoke those times to deatl. six, cight, or ten cigarettes. one right after the other. Kecp a gasper lit up and in your mouth or hand most of the rest of day ... and right.

i Aller a day or so, smoking is a chore, and a tiresome one at that. Your lungs begin to focl really heavy and your throat begins to rasp tar-

i. naturally.
Sleep, afler a day making like an conloug theat, is difficult. Your body is trying to tcll you something alarming.

Afler a few days, you'll be - Jike the guy with the nervous underarms, telling yourself, "IL's' working."

Salk told the six of us in Oversmolie Group B the technicue works abont 60 po: cent of the time--a rate for nicotine fiends, who are fanatic addicts.

My rate for the first lour days was 65 cigarettes. On the fifitin day, I bumped it in 80 . Salir had lold us discomfont does have a place in the therapy. I didn't find it with 65 cigarcile a day.

I have a very high discomfort threshold.

Eighty cigareties a day is more tircsome than uncomfortable. You have in smoke all day and half the night, non-stop. You lose your Gary Cooper cigaretle - lighting fechnique and your John Wayne squint - in - the - smoke gaze. Any Paul Muni class goos. You just sit and work your way through an incredible pali of acrid smoke.

lt's working.

At least Oversmoke $B$ gcts to stay with their regular brand. Oversmoke $A$ had to switcdi.

Two more froups aro gasping through the prostam. They are Lindersmoke $A$ and Undersmoke 13. They are supposed 10 be tapering off.

thry mobably are envious of the orersmote folk.

They shouidn't be. 

.
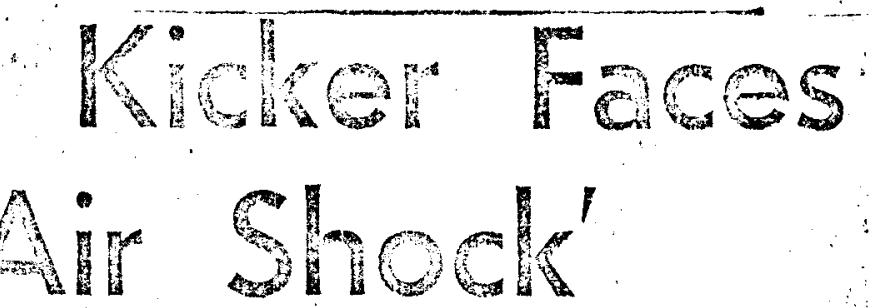

We called our group a c t I v i t y "Operation Oversmoke" becalse it required us to double nur cigarelte consumption for seven days and then quit, cold turkey.

The initial reaction to no smoke was simple relief.

But an old, old habit doesn't. work up fronl. It's more like a low whisper from the back row, niggling and insidious.

That bout wilh withdiawal symploms tumed cut to be a nonstop round of shadow boxing with mysolf - a very difficult sort of thing to win.

Some expectations have already been confirmed.

Salk fold us our sense of smoll would sharpen lp. He was right. Since going cold turkey, I can pick up cigarclte smoke from 100 fect in any direction.

A smokcr comldn't do that.

A researcher has published a study which showed night vision might be damaged by smoking, My night vision hasn't improved. Day vision may be dncaying, even. The first day of Operation Smokcless, I drove my faithful Beetle into the hack bumper of a pickup truck. The truck dirin't even illinch. The Beetle did.

Salk suggested fum or mints might be nkay as substitules, if anyone wanted to try them.

Mirds might be okat, but unless the cold turteyito is a strong fom man, chewine could lead lo "Santa Ama. "Jav."

This is whore you stull abeut threen sticts if from in at once als? wute on it. Ahout the midile of a chew, the novice chomper may let his jaw fall out of proper alignment: .

On the upswing, aulomatic altompts io restore aligument will rin up muscles or the ascondints ramus of the mandible and possibly damaere tendons therc. 'That's right in tront of the ear, at the hinge.

Il isn't much different from calching a stiff right hook.

Sanla Anna Jaw makes openings the mouth paimful. Faling is painiul. Concwing is almost impossible. It hurts.

The Alamo was orel in 13 days. T'exas aveneed that in six wecks. We have sulfered from chicle for more than a contury. Santa Anma. who introdised the sturf to America, got the last laugh.

Hahit kickers ane helter of? without more handicaps than they already face.

Salk fold us oly" sense of laste would improve. As soon as I can chew again, I'll try it. One's appetile is sunposed to improve. It probably will.

o peration Nosmoke rolunteces are supposed to gather at the veterans Administration tonight for a communal nail-chew. By then it will be five days. $A$ long lime. 


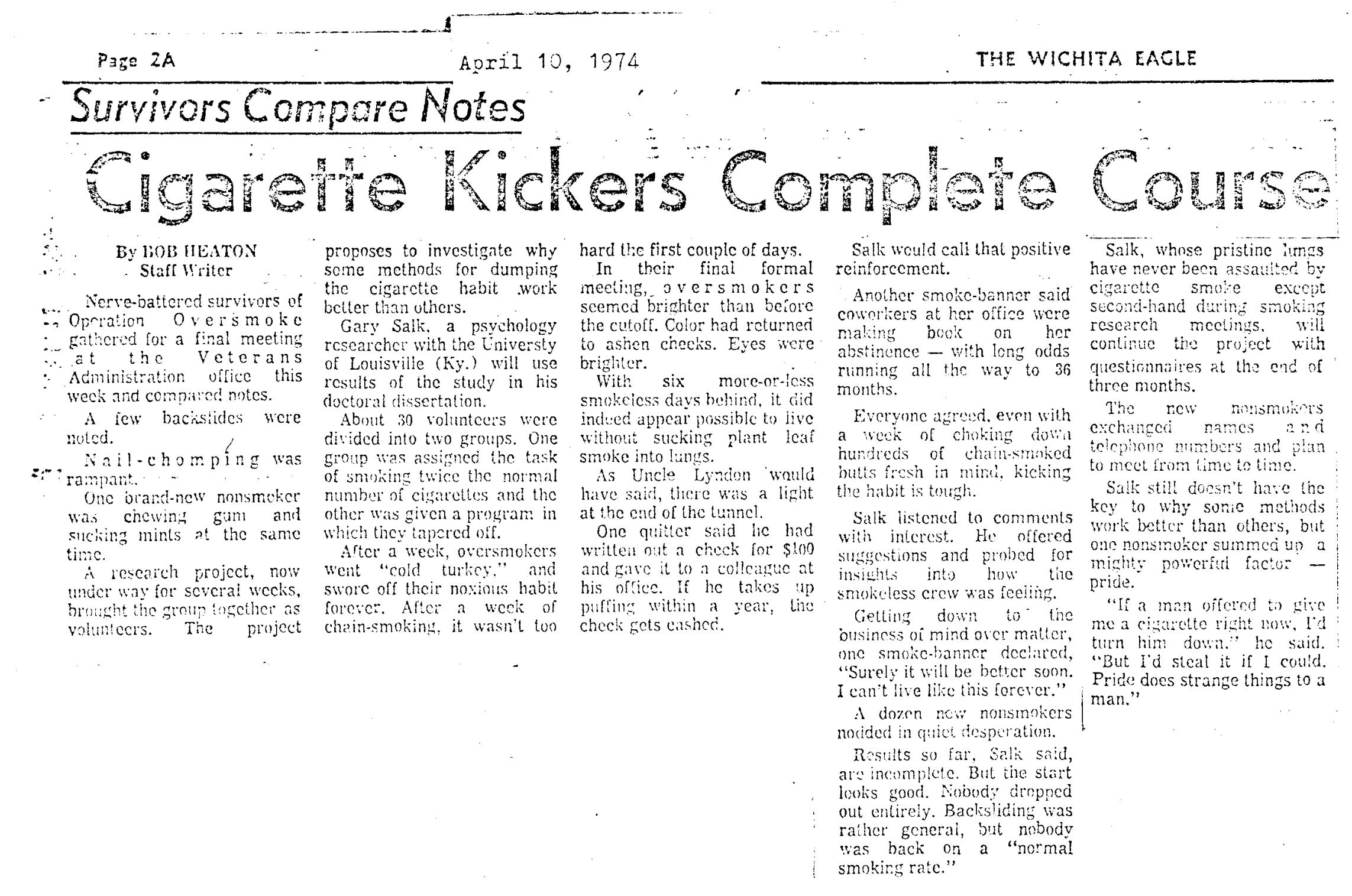




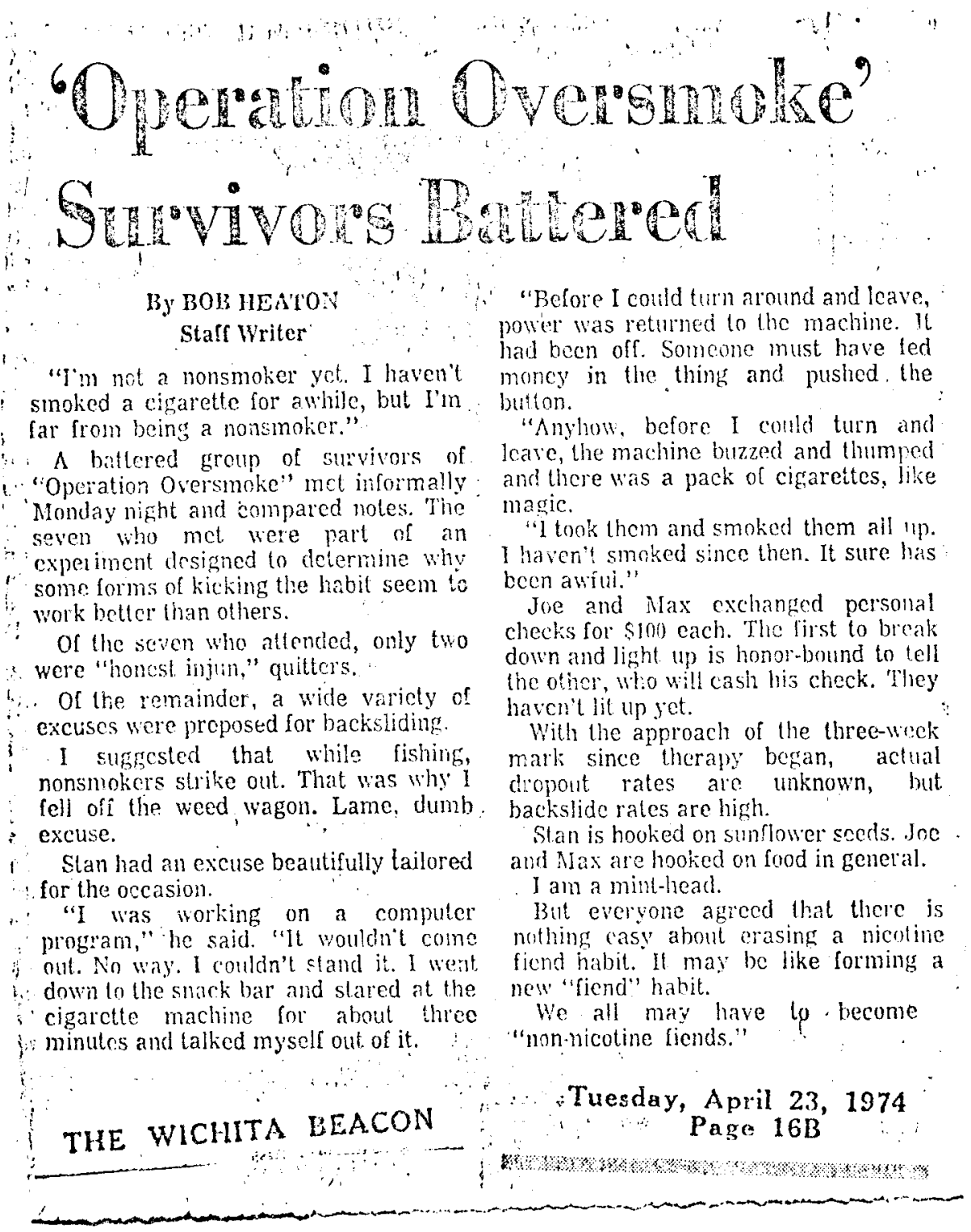




\section{For Some, It's a Pipe Dream Wichita Eagle JuIy 10, Pege 1 Voluneer Puffer Kicks Hobin-Often}

\section{BY BOB HEATON} Staff Writer

Operation Oversmoke is three months old. About 90 days ago, some so voiunteers gathered in the auditcrium at the Veterans Administration Center like pilgrims to a holy place and corfessed their desires to kick the habit.

No information has been officially gathored about how many have fallon by the wayside, but there is at least one.

Me.

Nicotine fiends are a bit devious. And tubborn. Asking why they smoke is liable to unleash a iull-blown disecrtation.

Gary Salh, a psychology researcher from the University of Iouisville ( $\mathrm{Ky}$.) is originator of the local program He prescribed bountifu! smoking for haif the voluntcers... double consumption. We were called oversmolers. The other half tapered off gradually. They were called undcismuke"s.
After a week of sucking in a cubic rile of smoke per day, we quit.

Our tar-pocked lungs thanked us.

But the nausea wore of and the old habits reasserted thcmselves. I fell of after about a montin.

Because I want to. Rigint.

Of course Salk lestroyed the old saw about nicoline being a relaxant or calmative.

In the morning, within six seconds of lignting up the first gasper of the day the smoker's blood pressiure jumps and the heart begins in work harder. Respiration begins to rise.

Tiny blood resseis in the haods and cet and cars constrict.

Some grcat men in history were mokers. So were some schnooks.

Some masnificent minds are at work in the advertising world, depicting smokers having more fun than you or I will ever have on the best day of our lives.
Some good brains also are working on scaring the ceils right out of the smoking fraternity. One-lung breathing and talking through a vibrator are things smokers would rather not think about.

Since returning to the weed, another shirt (a fayorite, of course) and a pair of slaciss have been holed.

So, back on the wagon.

One nice thing about quitting smoking. You can do it as ofter as you wish.

An old brush chopper in San Antonio use to bras he quit smching "30 or 40 times a day." . . .

Habit kiching as a sout might be like golf... the iower the scone, tho better.

Fipe smoking is no answer, cillicr. Cancer colls can waip mouth, threat and lips as easily as lunis. And after losing a $\$ \$ 00$ gold cap to a $\$ 2$ pipe, I think it is a false cconomy.

Nicetine fiends are weird people. The breathe the-sinote of smoldoring leaves because they like it. 
APPENDIX II

PERSOIMI DATA CARD

Name:

Aidress:

Fhone:

how cid were you when you started smoking?

How many times have you quit before?

What is the longest time you have quit smoking?

How much do you smoke each day?

Do you have any of these diseases: Heart trouble Bmphysenia

Chronic Bronchitis Cancer

Raynad's Disease Diabetes

Peptic Ulcer Asthma

High Blood Pressure

Peripheral Vascular Disease

Please write in any other lung or

cjrculatory disease you suffer from: 


\section{GHOWTI III

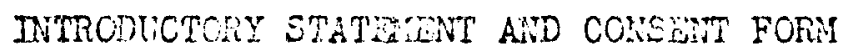

You are being asked to participgle in a sturiy to netemine acm: new weys to help people quit smoking. Haxf of you will be in a twontment An whon among other things you will be asked to donble your cmokfing rete for one wetk During this time you will neet for five Wekt deys with the other nembers of your group to see how well you are doing in this jian. The otier half of you will be involved in enother procedure that will take tiree weeks wich you will be asked to gradwaly rectrict your snoking during certain powtions of tho dey and to do cher tingug than soke durine these ufmes.

As jou rey have guessed the doubje sncktre conditfons ney be uncomfortatle and perhaps even risly to people with severe lung conditions; therefore, if you have any lurg conjtichs that would interfere Whth you smoking at double your uswal rate you will be asked to see your physician and ottajn his opinton as to whether on not thjs will hurt your health. If it w1ll hurt your health in you physician's opin.. ion, you hitll be asked not to participate in this study.

If you aro able to continie with this procedure you do stand a gcod clance of being able to quit srcking. Of course we all know the dangers of smoking end the perle in both groups who are able to quit, saoking vil onjoy quit: probakjs much better heaith in the future and wil be mach more plessant to their fichis and associctes as a result ô the trontmon.

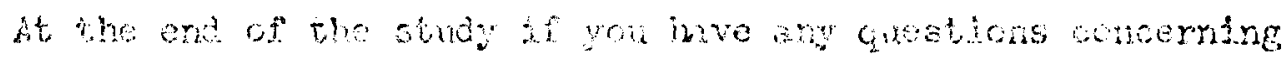


any of the procedures that you are involved in please feel free to contact $h_{m}$. Salk at the Veterans dairistration and he will be very happy to answer your questions. You are, of course, free to withdraw Iror the progran at any tine. However, if you should withdraw you will forfeit the portion of your deposit that you have not had returned to you by that date.

GARI C. SAYK, M.A.

Psychology Intern

This is to certify that I have read the above statement and fuily understand the risks, advantages and procedures involved in the study and do voluntarily consent to participate in it, and I request I be placed in this study.

Signature: 
APPENDIX IV

COVER LETTEA FOR FOLLOW UT I

His!

The time has come for the three-month follow up on the smoking project. As you may remember, you will get $\$ 10$ back for completing this follow up independent of whether or not the program worked for you. I am mainly interested in accurate infomation and geting infomation from all of the people who participated in the project. What you will have to do is to flll out the enclosed questionnairc completely, and keep a smoking diary for the next thrce days. The same rules as before apply to the smoking diaries: 1) record al] cigarettes smoked, whether they are begged, borrowed or stolen; 2) record the time of every cigarette; 3) give a brief description of the clrcumstances of the cigarette; 4) give the date that goes with each record; and 5) please write legibly.

Please remember that $\$ 10$ of your deposit will be refunded when you return these completed records. You can still get your deposit back even if you did not complete the treatment and lost the first $\$ 20$, so please return your records promptiy.

Thanks. 


\section{APPENJTK V}

COVIF LETTES FOR FOLLON UP 2

$\mathrm{HI!}$

Here I am for the last time. As before, please remember that I'r after accuracy and getting correct information. I was very plessed to hear from al of the people who completed the program lagt time and bope to get conplete information again.

What you will heve to do again is to fill out the enclosed questionraire completely, and keep a smoking diary for the next triree days. The same mles as before apply to the snoking diaries: 1) record all cigarettes woked, whether they are beged, borroved, or stolen; 2) record the time of every cigarette; 3) give a brief description of the circumstances of the cigarette; 4) give the date that goes with each record; and 5) please write legtbly. Please remenber the diary is the most important piece of information I receive.

Please remember that $\$ 10$ of your deposit will be refunded when you return these completed records. You can still get your deposit back even if you did not complete the treatment and lost the first $\$ 30$, so please return your records promptly.

Thenk you very much for your cooperation in this project. I w112 be sending the results to Bob Heaton of the Lagle. 


\section{APPEINIX VI \\ SNOK ING QUESTIONNAIRE FOR FOLLOW UP I \\ SMOK TNG QUESTIONNATRE}

Please fijl out and return with smoking dfary.

1. How would you describe your smoking pattern since the smoking project?

A. Quit ano haven't smoked since.

B. Had a few cigarettes (Jess than one pack total).

C. On and off smoking.

D. Smoking less than before the project.

E. Sinoking the sume as before the pruject.

F. Smoking morc than before the project.

G. Smoked \& little after the program, but quit and haven't smoked since.

H. Quit after the program, but started smoking again and still do.

I. Other pattern (please describe)

2. Have you had any cigarettes in the last week? Yes No

3. What elenents of the program were most helpful to you? 
4. What elenents were lesst helpful to you?

5. What is the longest period you have been off cigarottes since the end of the program?

A. Continuously - haven't had a cigarette since the end of the program.

B. Hore than two nonths.

C. I month.

D. 3 weeks.

E. 2 weoks.

F. I week.

G. Less than I week.

H. Never quit.

6. What advice would you give me if I were starting another smoking program now? 


\section{MPIENLIX VIX}

SMOK TNG QUESTIONAIIT FOR FOLLOW UP 2

\section{SMOKING QUESTTOWATEE}

Please fill out and return with sinoking diary.

1. How would you describe your smoking pattern since the smaking project?

A. Quit and haven't smoked since.

B. Had a few cigarettes (less than one pack total).

C. On and off smoking.

D. Smoking less than before the project.

E. Smoking the same as before the project.

F. Smoking more than before the project.

G. Smoked a little after the program, but quit and haven't smoked since.

H. Quit after the program, but started smoking again and still. do.

I. Other pattern (please describe)

2. Fiave you had ary clgarettes in the last week? Yes No

3. What elements of the program wore most helpiul to you? 
4. What, elements wore least helprul to you?

5. Whet is the longest period you have been off cigarettes since the end of the program?

A. Continuously - hoven't had a clgarette since the end of the progran.

B. More than four months.

c. Fore than two monthe.

D. I Inorth.

E. 3 weeks.

F. 2 weeks.

G. I week.

H. Less than I week.

I. Never quit.

6. lhat advice would you give me if I were atarting another smoking program now? 


\section{APPENDTY VIII \\ COVER LETITR FOR SHCOND MAILING OF FOLLOW UP 2}

Deer

This is a reminder about your snoking diary and questionnalre. I'm sure you understand my anxiety to bring this project to a close and be done with it after all these months.

of the tivo pieces of information, the diary and the questionnaire, the diary is the nost important. Pleasa use the enclosed envelope to return it and the questionneire at your earliest convenience.

Sincerely,

Gary C. Salk 
AFFIIDIX IX

VERTATUM RESPONES TO QUASTIONMATFE TTEM 1, I. OF FOLLOW UP 1 :

"how would you describe your smoking pattern since the suoking project? ... I. Other pattern (please describe)"

Subiect 1. If at a party or out with friends, I'II bun a couple of cigaretteg then I won't touch one for a weak. I feel like an occagional "social snoker."

Stbject 4. I have one cigarette when I wake up early (veualiy). At work I snoke about as I did before the program. On the weekends when I em home alone, I smoke aluost as much as I did before. Subject. 5. Before program snoked strongest cigarette I could get-always--Now smoke cigarettes with filter and milder I've never snoked stronger brand since with exception of ty pig. Dia cut down anount of moking for 2 or 3 weeks.

Subject 1. Hadnt had any up to 7-5-74 then smcked 1 one day then 3 next day ana looks like I am fastly accelerating to old habits but still want to quiti.

Subject 11. I've had periods of extreme desire for cigarettes. After smoking one or two, however, the sick feelings would return and the desjre would disappear.

Subject 22. Completely quit for appror 3 weeks, then started smoking after meals. Now, have fimly limited smoking to 4 clgs per dayalnost exclustvely following weals and usually B-4 bed. Frequently if have evening plans will save cig following meals for evening. Of some help was telling entire office staff that I had 'quit' sinoking. When started sroking after meals was ahaned to let people in office see or 
know. Aiso had jaritor remove all asntrays from building except in waiting or lobby area. 


\section{APFANDIX $\mathrm{X}$}

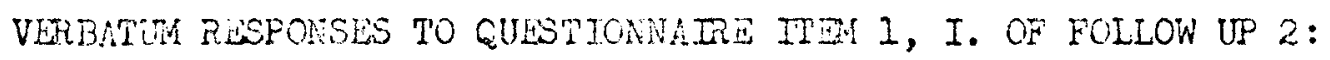

"How would you describe your" sncking pattern since the smokjng project? ... I. Other pattern (please describe)"

Sibject 11. Snoke zero during day--smoke 4-5 ir evening.

Subject 11. I did not have a cigarette for apx. 3 ints after project.

However, of late I have been smoking about 20 cigareties every three to

four days.

Subject 29. I smoked on and of but had cut dcin and have quit since the first of actober. 


\begin{abstract}
WPWT $\mathrm{XI}$

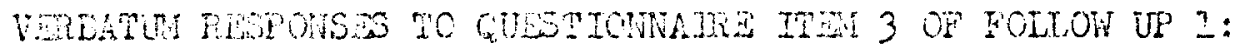

"What elments of the program vore most helpeul to you?"
\end{abstract}

Subject . (contol) I think, if I had continued, breaking the pattern of my noleing world have beliged. I ganed quite an instght to wy suokine rout by roping the ciary.

subied 1. Jouble smoking and having to keep a diary so that I was Evare of whot it was doing

Sugrop. Double amoking killed my desire to anoke ai first, but as that gasty oxperisnee fared, it fell to personal rotivation for con-

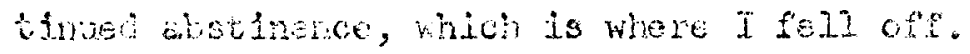

Supiest $2.6 r o u$ suport.

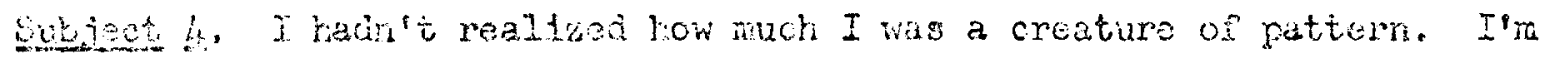
stal. trythe not to buidd new habit patterne, but they are creeping up. Subjegt 5. Wing an approach with a method that made good sense and one T believed in (stiz do). Weeting once each dey with others intending to qujt smoking. Anojance of writing down each cigarette and snetimes srokijs when I really didu't want to. Wxcitenent at idea of "raybe it's possibla."

Gubtect 6. The group sesetons were the nost effective part. The enconder with your fellow mokere dodel to the intamal conseience to wake lue dostre to guit stronger.

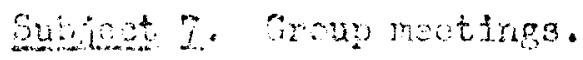

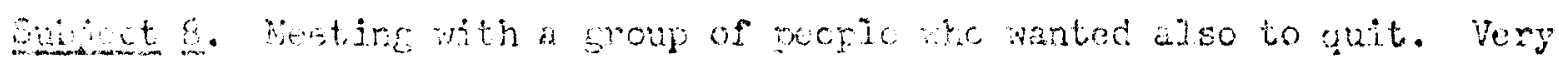

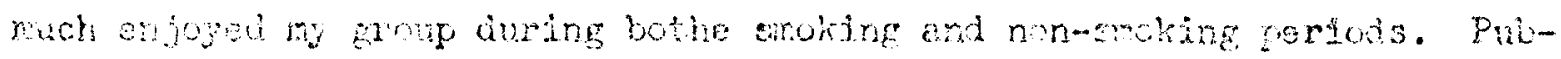




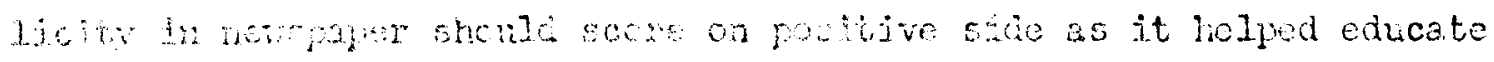
ron srougs and somed as an enditical incentive. (as did the checks mase wat. to Canew Soctety).

Sudect 9. Crow therapy and our own privete croup afterwards. Subjed 10. The fejowshp of the others that were trying to guit.

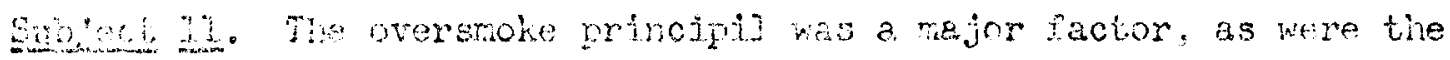

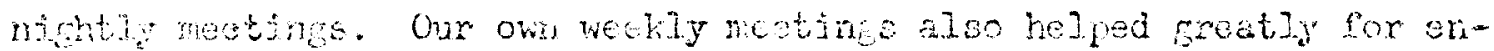
$\operatorname{cowhengat}$.

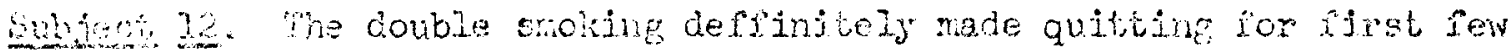
vays thoh saelen.

Sublect 12 . The orermoking nede it very clear to the what effect stacking was having on he. I thought the group aessions were very helpful and wowi save helped Ereaty fr the tiro when I was trying to do with out.

Subied Is. I balieve the recording of exch cigarette smoked-ana the doubing up the first period-recordine was so monotonous-doukling so sickeadig-and the daijy reports and metetng with you at V.A.'s time consting and expensive for a darned cigarette. Subiecti2. Dowbing.

Subfoct 16. Hecting as a group ami knowing that we were all going tircuth the sarie "misery".

Subjegt Ir. (1) Changing brends of cigerettes. (2) Discuseion with other frifviduis attempting to top onoking. (3) Keeping the diaries. Sulfert re. Sroking disty very helpruli.

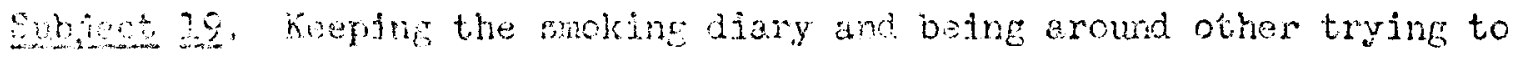
girit.

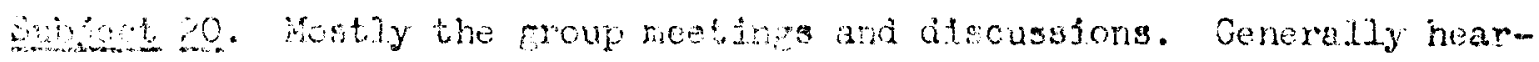




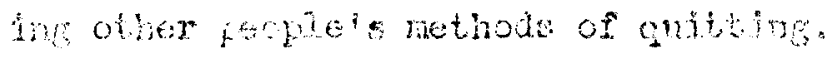

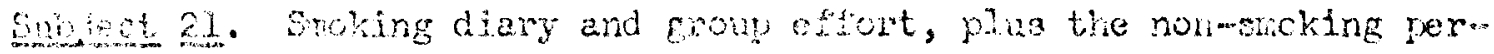
sols helpat brek the autonate smowns hatit.

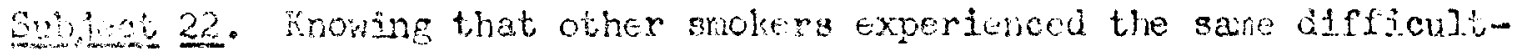

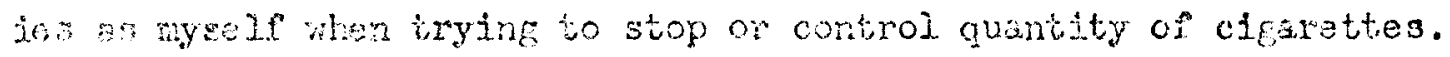
Also lesping the diary was helpful. I snoked so much it was impossible to establiah a patern, but heiped mo awne of just how man cig's I sotuing jit. th one day.

Subject 23. Wowtrg chat other yeche wore sufertng ane things. mie

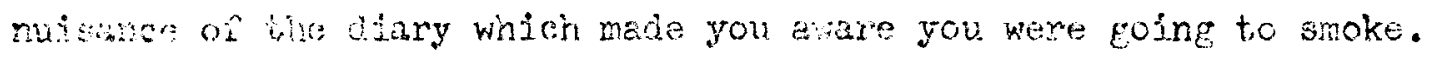
Subjet 24. That of discussing wht the other people substituted for grating.

Subiegt 25. Coup discussion and motivation. Smoking diarios.

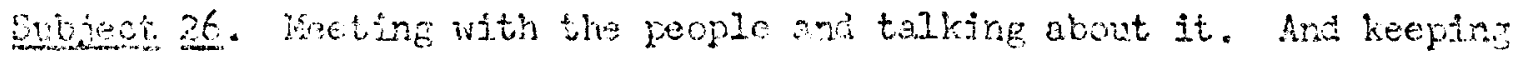
ihe ifary.

Subiget 27. Filling out the smoktng diaries. It gives you a chence to "geifonalize" your habit.

Subjed 28. I feel that keeping a diary of all cigarettes sinoked was a deterant, but it is a bis headahe to continue from here on ouc. Sulves 22. Bncwing I wasn't the only one brylng, keeplng track of cigarettes. Subject 30. Diary. 


\section{AONDI. YII}

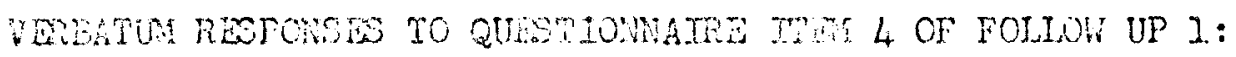

"What eicments vere least he?ptil to you?"

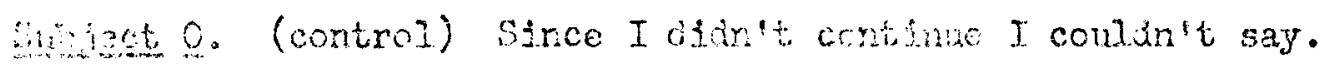
Subl. I have ntred feeling ebout the roup metings. I enfoged then, hut they weren't worth travel tire and distance for me.

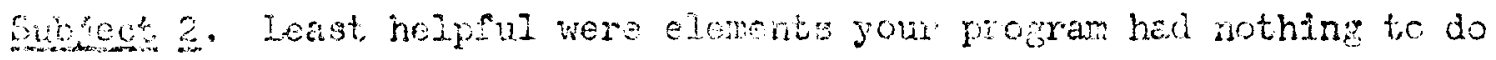

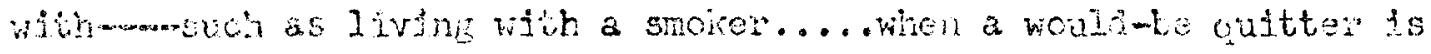
expoes tw wokne on a more cr less contant besis, rotoluriton sortens and is dipficut to matatein.....ef course this could be just enother way to excuse returning to the wod. Motivaton, as you said, is paramown. Tour program requines higin motiwation.

Subiet 4. Whe dam diary. As you recall, I deroloped a bad cough ll Irowire that every cigarette was going to bring it on vas a mild tortorowatidentaly the cough 13 gone.

Subsect 2. Can't tinink of ary. Subfoct S. I carte really think of any except lack of 16 below. Sulject $7 . ?$

Gablect E. Cant thine of ayg-as at the time, I felt I needed ail the help 1 cond reet?

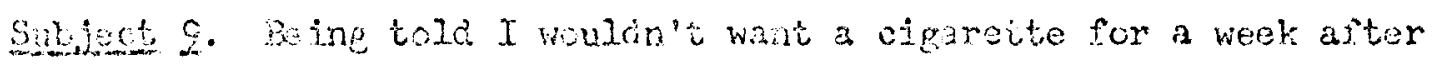
snoklng conble for a week.

Swited in. The lack of follow up imodiately-at had atartod again when

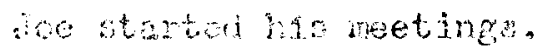

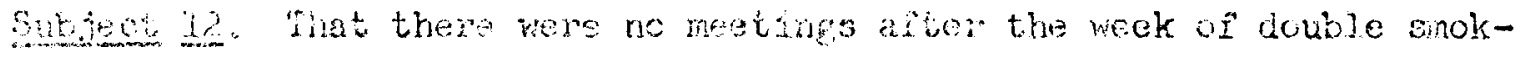


ing.

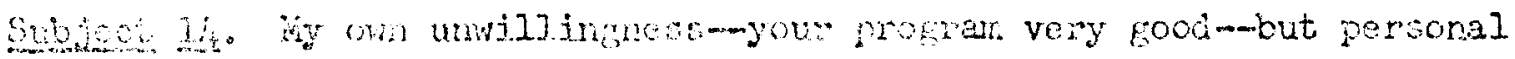
mokicus bvent helped re to be stiong as I should be.

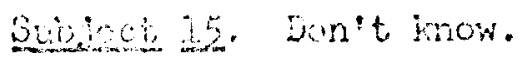

sudete Changing brands of cigarettes.

Sulest 13. Discusoion or othera" trials and tribulations.

Subject 10. Bverything seemed to hely but after the propkan was over I stili had the desje and not enough wiliponer.

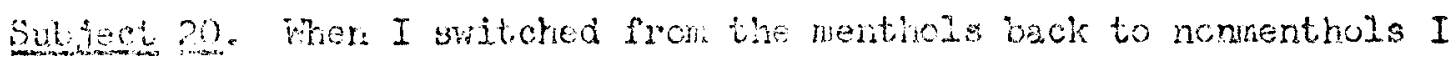

Jiked the ojorette and snoked just as much as previously.

Sybject 21. List of reasons to guit snoking, substitutions.

Subjes an. Depositing checks were of no halp.

Subjed. 23. Cant think of anything in particular.

Subject 25. Tapering off.

Subicos 20. Sritching brands.

subject 27. I feel the tapering off program was not long enough and more mething necded to be held. I was real disappointed that the final meeting corstsied of you telijng me to quit......period. I fesl I could have heen wold that at the first neeting and been as successful. Qubegt 20. Oral replacements fow the cigarettes worked for a while, but you get bumt cut on gun and toothpicks in only a short period of. sine.

Subject 29. I ddart find anything that detreted from the program. Gubject 20. Nonc-jurine the project. I was very sware of my smokirg therefont I semed to cut down. 


\section{AWWOTH XILI}

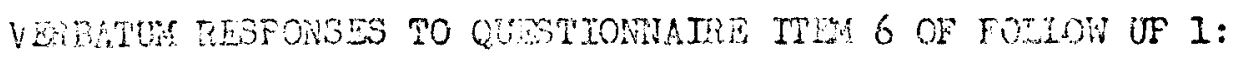

"What avice would you give the if I were stant ing another omoking program now?"

Sulfere 9. (control) None, exeert hap up the sood wort?

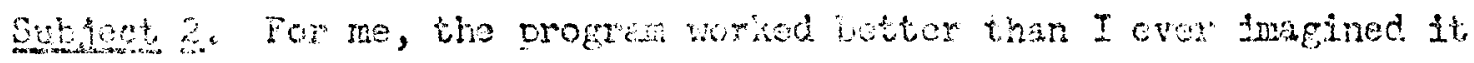

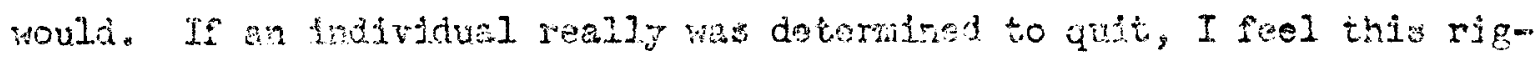

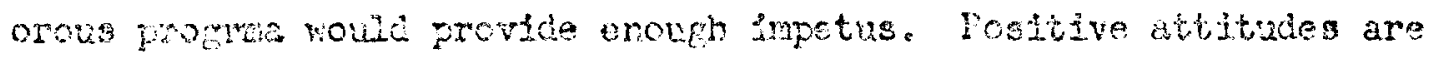
pretry tough to raintain... I rosily had the feeling at finst it wouldo:

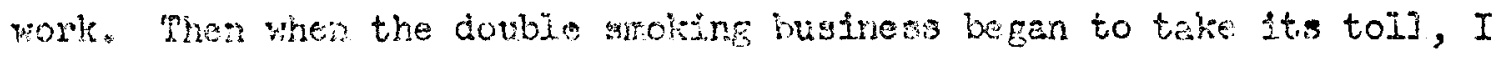

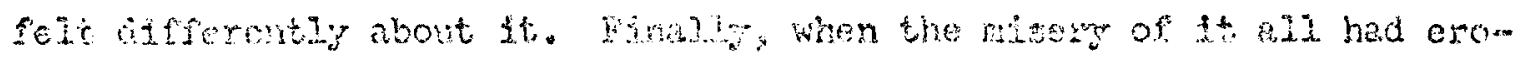
ded. I fond ryself drixting back dnto anokng, pretty inch the seme yatterns as before parlicipation in the progran.

Sultect 3. Weokly group meetings.

Subject 2 . Carry on whth a follow up program. The one we developed res helprul, but because we hed no rocal polnt (jou) we ware airlese and I soon quit going.

Subject 2. Meet every day for awhila at end of program while romentum is at pozk. This could rery posatbly be heipful to some. Wll other anpects of program are exceluent: Fersonaliy fee? I falled-riot the programe

Sribiet 6. Conthuoue follow-ip for at least two month sponsored by gon win these sessiong betng inclided in the term "completton of the progrant. The group shond bo conthown, becange st's the peer presEves that poss the larthest. 


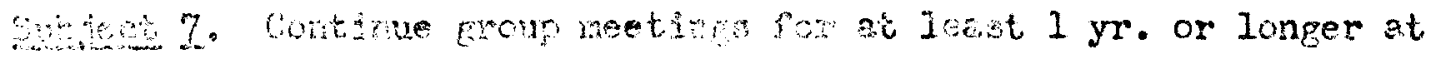
inditidele rothtary dscrotfon.

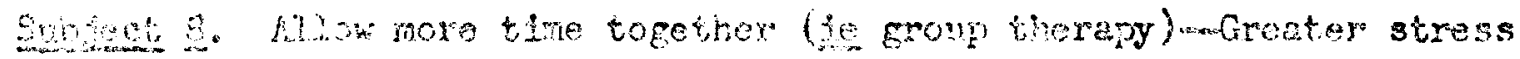

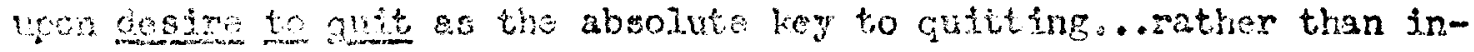
conseting or decreasing groups as patteris. The "crodell" we went thru (Atrifes ard trotment plans) hejped to dinjke cigarettes por a time,

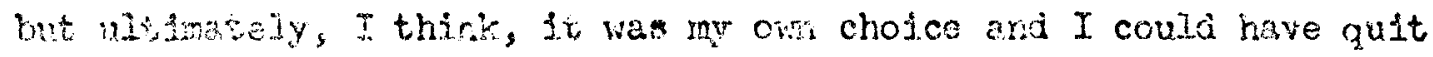

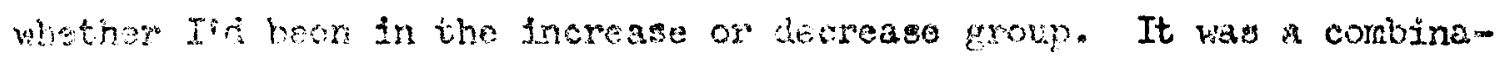
thor of dogze and moral support that made ne a gonmonolier.

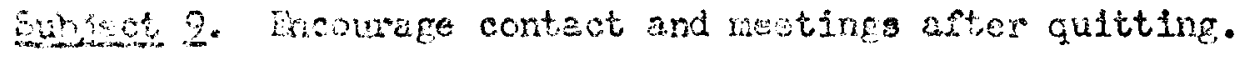
out sot 10. Jonger treatment pertod whabe meetings spaced ont to every 2 or 3 hays, aftes firgt weok, for 4 to 6 weoks.

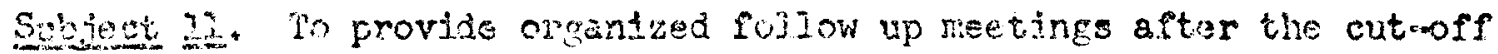

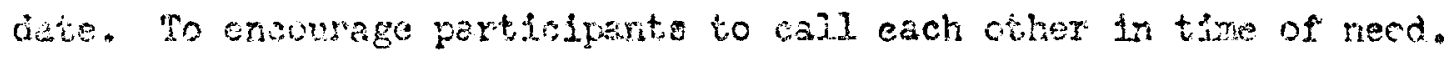
Siljegt. 12. I would suggest that netings be held for 5 nighis when we gute and at lecet 2 times a week thore after. I d ld rot snoke (after I

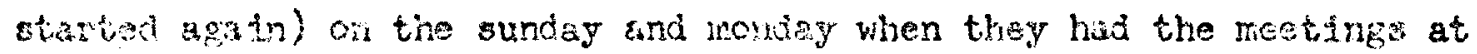
State fsm. on nonday. I think that the roral eupport and heip during ire $I$ at 3 montiss is rery impertani at least for ne. Subiest 12. To require the participante to nest dajly for the first weel of quitting and then on a less often besls thru the filst month. Quject I4. Jaybe viaual aids of denage to lungs-Azo more freouent meting, poriens every day for growp discussion, einilar to A.A. whore ore person helpo another to refren tron the smokng-or written facts cosecraling derage to cur bodies which isn't virable.

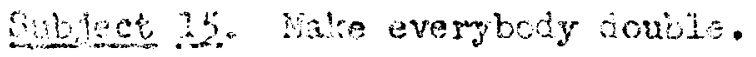

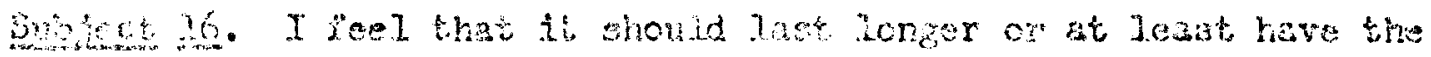




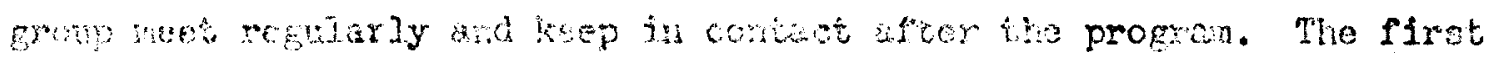

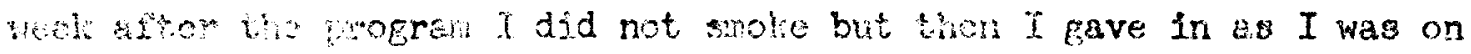
ny wh agin

Sulece 39. (1) More publeity to attract porran membera. (2) But-

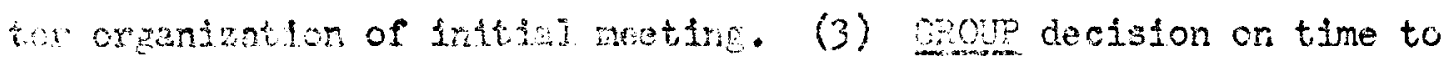
$\mathrm{mat}$.

Sosect yo. I wah I could tell you, beouse $T$ still want to quit.

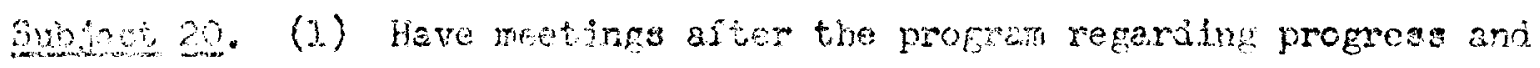

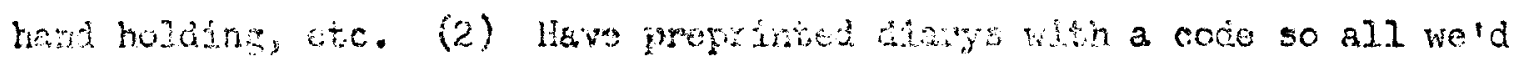

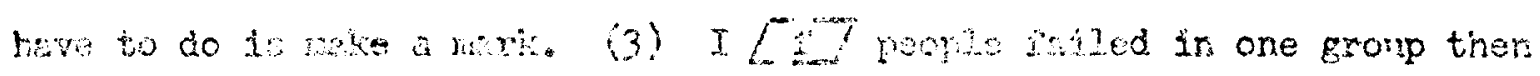
go thru chiser progan.

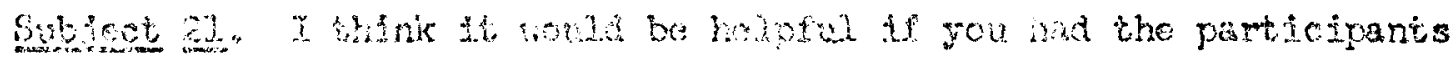

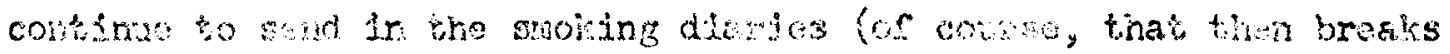

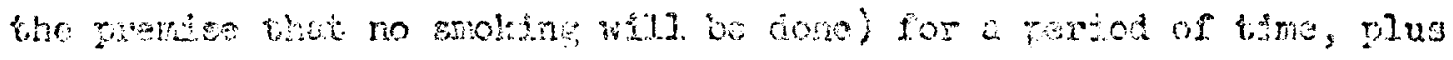

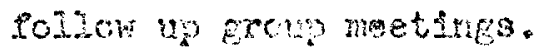

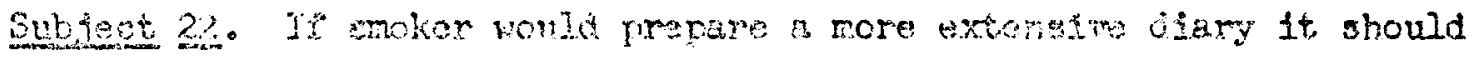

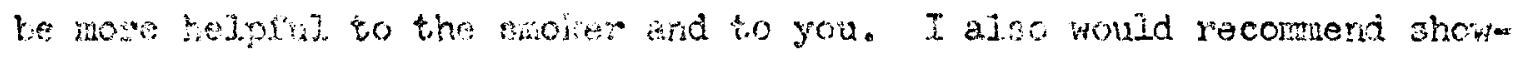

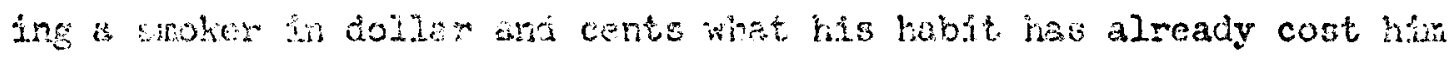

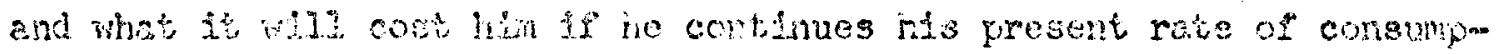

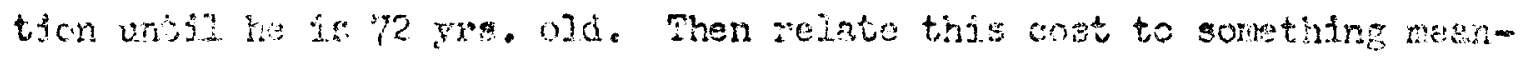

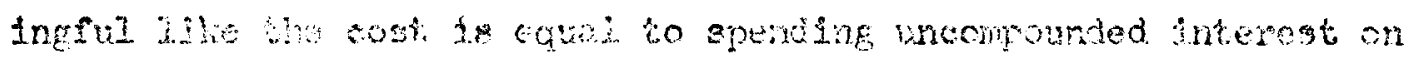
$\$ 100,000$ each day. Anowher potht I don's beliovo hes best widely put-

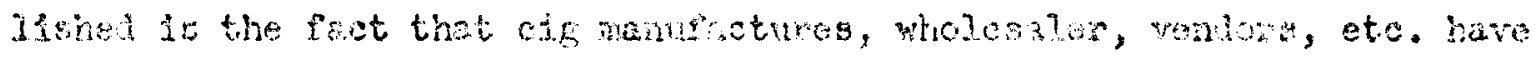

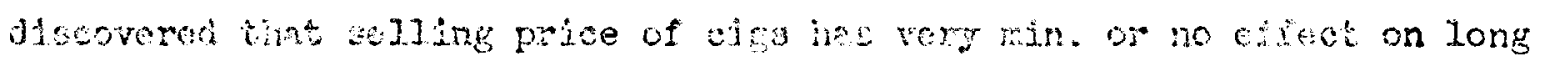

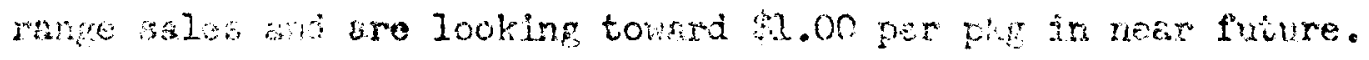

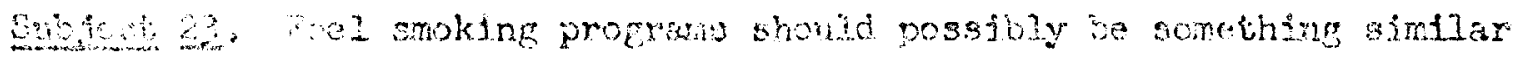

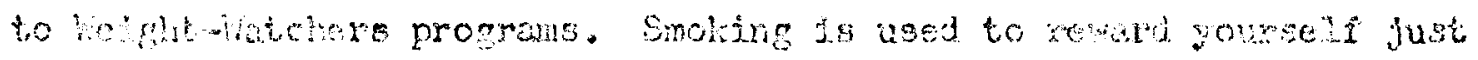




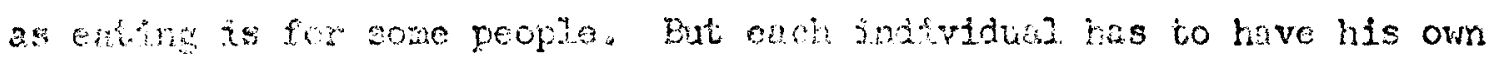
motuc for stopitse.

Sublegt 21. I wild like to see partictrints get to choose which method; dowiting or gadually quitting, they were to vae.

Suniect 25. (i) Incourage contimued group partiodpation after cigar-

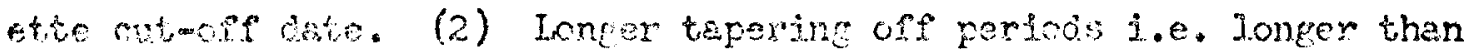
ore hour per period. I felt that frmily suport throughout inis profect Was esventah.

Subjent 26. lave it consentive nghts for everyboty and follow up

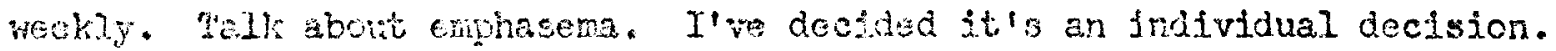
Subieds who hus wholed and hed quit would be better able to conduct the progian. (I an rot tojing to you showd sort suking). Svifert 28. It would sear as though the best way to stop smolthe wolid be to overdue fit untll you would be repulsed by them as opposed to try fing to depend or will power and subistutes. Desire has to be the biggest. motivations

Subject 39. $x$ think poosibiy a meeting or two at weekly intervals arter the flual quitifng to give "roral support" or perhaps "hand spanking". Perhape, the loce of the $\$ 10.00$ fit the "ex" moker started back durtrg those 2 weeks after quitting. I sincerely belfeve if I hadn't gone home to Penoncola; although nerves are ne excue, I an extremely nervous around ny fondly, I'm mach more avare of mo smoking and have "quit" off and or since the portam. Gubjes 20. The diary should be a continual process until the three nontil tolion up. 


\section{APYOWX XTV}

Mat $20 \%$

\begin{tabular}{|c|c|c|c|c|}
\hline Groups & 10ject & Base $B$ & Follow Uo $1^{2}$ & Follow Uo $2^{3}$ \\
\hline $0 \times+1$ & $\begin{array}{l}3 \\
2 \\
3 \\
4 \\
5 \\
6 \\
7\end{array}$ & $\begin{array}{l}17.0 \\
32.5 \\
39.3 \\
26.8 \\
44.9 \\
20 . \% \\
16.5\end{array}$ & $\begin{array}{r}1.0 \\
24.3 \\
30.7 \\
7.3 \\
46.0 \\
22.7 \\
10.3\end{array}$ & $\begin{array}{r}14.0 \\
21+.0 \\
29.3 \\
0 \\
50.3 \\
25.7 \\
18.3\end{array}$ \\
\hline$[1 . \pm 0$ & $\begin{array}{r}8 \\
9 \\
10 \\
13 \\
12 \\
33 \\
116 \\
25\end{array}$ & $\begin{array}{l}20.0 \\
17.0 \\
22.2 \\
24.7 \\
37.1 \\
34.0 \\
24.9 \\
22.9\end{array}$ & $\begin{array}{r}0 \\
15.7 \\
40.7 \\
0 \\
32.0 \\
34.0 \\
26.3 \\
0\end{array}$ & $\begin{array}{r}0 \\
21.3 \\
33.3 \\
4.0 \\
42.7 \\
35.7 \\
19.0 \\
0\end{array}$ \\
\hline$\pi-31$ & $\begin{array}{l}16 \\
17 \\
18 \\
19 \\
20 \\
21\end{array}$ & $\begin{array}{l}25.6 \\
36.0 \\
13.3 \\
22.3 \\
21.5 \\
31.2\end{array}$ & $\begin{array}{r}12.7 \\
0 \\
12.3 \\
15.3 \\
22.7 \\
9.3\end{array}$ & $\begin{array}{l}20.0 \\
5.0 \\
13.3 \\
19.0 \\
19.0 \\
19.3\end{array}$ \\
\hline$V-i o$ & $\begin{array}{l}22 \\
23 \\
24 \\
25 \\
26 \\
28 \\
28 \\
29 \\
30\end{array}$ & $\begin{array}{l}52.4 \\
30.7 \\
46.0 \\
20.8 \\
38.7 \\
36.2 \\
22.9 \\
32.0 \\
23.0\end{array}$ & $\begin{array}{r}3.7 \\
0 \\
35.3 \\
0 \\
33.0 \\
19.0 \\
0 \\
12.3 \\
11.3\end{array}$ & $\begin{array}{r}9.7 \\
0 \\
38.3 \\
9.3 \\
31.7 \\
23.0 \\
9.3 \\
0 \\
18.3\end{array}$ \\
\hline
\end{tabular}

Tluan mumer of cipareties smoked per day durlng a eix-day base veriod.

2 pesn number of cjerrettes smoked per day during a three-day sollowng perioa at three to sve months anter treatuent.

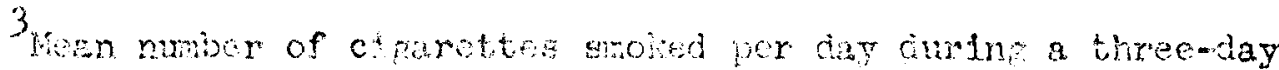
followm yeriod at sily to elub nonth after treatmont. 


\begin{abstract}
APPENDTX $\quad Y V$
VERATUR RESPONSES TO QULTIONMIRT TREM 3 OF FOLLOW UP 2:

"What elenisnts of the program vere most helpful to you?"
\end{abstract}

Subiect 0. (control) Keening the diary help bring to my attention the patterns of ing sroking.

Subjoct 2. The discipline of keeping tie diary and the doubje snoking. Subject 2. The group interaction, combined with the awful business of double-smoking, made the program vork for a time.

Subiect 2. Group support. Interested psychologist.

Subject 5 . Could have been writing each cigarette and time and association with others who wanted to quit smokjing.

Subfect 6. The counseltrig sessions with its group rapport.

Subject 7. meeting with the group, as we continued to have the weekiy meetings after your program stoped and long as we had the meetirgs I did not snoke but when ve stopped the meetings, I started smoking.

Subject 8. Group encounter, open communication within the group.

Subject 2. Group discussion.

Subject 10. The meetings together.

Subject II. Oversmoke and group meetings.

Subjecs 12. Double smoking help get off cigs initially.

Subject 13. group meetings--Doubie smoking made the effects of smoking very clear.

Subject y. Recording of smoking (really bugs me to think I'm a slave to the hablt each tiste I have to write it down). Aleo the doubling up of smoring. 
Subject 15. douvith and having to keop track of all those I did smoke. Suipject 16. Group discussions ant contact.

Subject 17. Keeping a diary. Changtng brands.

Subject 1g. Keeping the diary, scoing smoking as bringing discomfort to others.

Subject 19. At the time I think the meetings were the nost helpful. Subject 20. Mieetings.

Subject 21. Smoking log.

Sublect 22. Contact with people with the same desire (to quit smoking)

as I had. Recording and observing the pattern I smoked.

Subject 23. Yeeting with people who had the same problem. And it realiy helped to keep the cigarettes in a part of the house where I had to go after them one at a time. Subject 2ly. Discussion with other people about their problems quititing smoking.

Subject 25. Idea of substituting various things for cigarattes. Subject 26. probably keeping a diary and changing brands of cigs. Subject 27. Keeping the diary and realizing how much I did smoke. Subject 28. Learning my patterns and watching them in order to cut down my heary moking times. I no longer smoke at hore, but still do at work although less than before. Subjeat 22. Thinking of the herm of cigarettes and becoming concious of the anount of cigerettes I smoked in a day. Subfect 20. Daily Log. 
DPMTES XVI

VERBATU RESFONSES TO QUGOTIONIATHE TTZM 4 OF FOLIOV UP 2:

"What elements were least helpful to you?"

Subject D. (control) Didn't complete the project, so really couldn't say.

Subject 2. My own attitude.

Subfect 3. Can't think of ariy.

Subject S. All were helpsul but least was probably the money aspect.

Subfect 20. I don't honestiy feel the over-smoke was all that helpful.

Subjecs 22. None

Subject 16. Changing brands of cigareties.

Subject 19. Listening to extraneous experzences of others (I realize

this is not your doing).

Subject 12. I think the postponement of a smoke for a period of time after meals was the least helpful.

Subfect 2l. Writing down why you shouldn't snoke.

Subject 22. Deposit.

Subject 23 . Can't think of any.

Subject 25. All sbout the same.

Subject 26. Not enough emphasts on physical addiction--reaction to quittingwilet $[?]$ etc.

Subjest 27. I felt tho cutitue down program WASN'T going to work from the start.

Subfect 28. Other oral bubstitutes didn't soem to helf me much.

Subject 29. I didn't fint ary of the program that wasn't hejpful. 
Subject 20. They were ell very important-murfng the clinfe I was fatally akere of each cigarette I snoked thus Biding [?] me to cut down considerably. 


\section{ATPETDIX XVII}

VERBATUM RESPONSES TO QUESTIONAIRE TTEA 6 , OF FOLLON UF 2 :

"What advice would you give me if I vere

starting another smoking progran now?"

Subjest 2. Lean Hervily on Necessity for selfiriotivation, as well as group interaction.

Subject 3. Fore group follow-up, especially the first month.

Subject 2. Some meetings following program - during times when one vas supposed to be "off" cigarettes. Belleve this to be a great program even though I was a failure at it.

Subject 6. Follow-up sessions for a longer more closely supervised period with the chance for peer pressure to take effect more strongly. Subject 7. Keep the weekly meetings going.

Subject 8 . Would tave liked to have met on a more frequent basts. Very much appreciated the reinforcenent of peer group. The publicity element was great. (The Wichlta Eagle-Beacon) write ups heIped educate the public \& us-giving us recognition as further reinforcement. Subject 10. To continue the meetings over a longer perlod. By the time I found out Joe was going on with the "follow-through" I had become discouraged \& resumed smoking.

Subject 11. Longer follow up meetings \& some "punishment" or treatment for cheating.

Subfect 12. Have less metings ciuring the inititial stages of Programe and increase meetings after the quit date as that is time winen moral support is necesssry. Ȧ]so. Some descriptive photos or samples of 
what a Smokers Lungs look like j.e. The Frjght Phsycology. Supject 12. Carrying the dally pargrems thru the initial couple of weeks of non-smoking. They are needed then even more than during the doubling period.

Subject 14. Visual aids and more concentration on the harmful effects of cigarettes at begiming of program-and maybe a longer period of meetings. I am going to continue the recording of my smoking in hopes it will irrftate me so much I'll finally give up on the nicotine. Subject. 15. have everone double. They'll really get sick of them like I did.

Subject 28 . Betier organtzation \& preparation of initial meeting. Subject 19. I have no advice to give. Subject 20. Possibly periodic ritgs ifter your ortginal program--I realize you vere not attempting to insure our stopping smoking but merely a cross sectional research it reaily was (is) up to us. Subject 22. More emphasis on awareness of smoking. Subject 23. Possibly asking each person in turn to describe the past week's experience. Eut a person must have a real reason for quitting. Subject 24 . Let the people decided what method they would use to quit sinoking. Dont let motbers talk their sons into taking course. Subject 25. none.

Subject 26. Use a T.A. type situation-- Draving up contract-setting time for quiting--reienforced with diet plans. No stimulants etc. I think this is going to be my approach to quit smoking. I don't think it can be an independent type trangaction-because I need soneone to help me set up the contract. Subject 27. As I sald before, without you ever smoking, I feel you 


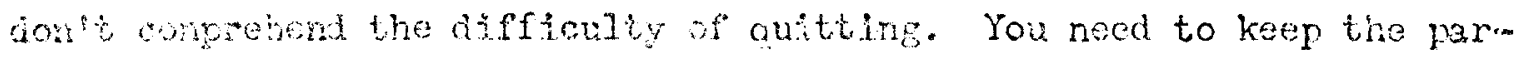
ticipant rere involved and not roly or them doing this on thier own. Maybe meting 2 or 3 times a week instoad of once a meek. Subjegt 28. Whe sure people have the correct attitude \& intent desire to quit. Stress the reed to leam their owr patterns in order to find ont when where they are the most jikely to smoke heavily. Subfos 22. The same as I gave in the last letter porhaps if the

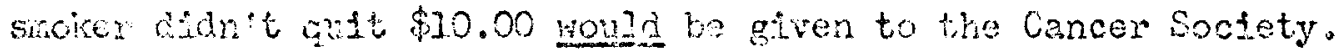
Subject 30 . continue the daily jog through a longer periud than just the cilnidunastosibly through the slx nonth feriod. 


\section{REFERENCES}

Azrin, N. If., \& Powell, J. Behavioral engireering: the reduction of moking behavior by a condjtionirig apparetus and procedure. Journal of Apolied Eehavioy Analysis, 1968, 1, 193-200.

Per, D. J. Hejght, weight, and ponderal index of college male smokers and ronsmokers. Journal of Prychologr, 1966, 64, 101-105.

Berecz, J. Modification of smoking vehavior through self-administered punishment of iragined behavior: A new spprcach to aversion therapy. Journs of Coneviting and Clinical Psychology, 1972 , $38,244-250$.

Carlin, A. S. \& Armstrons, H. E. Aversion conditioning: Leaming or dissonance reduction? Jourrel of Consuleing and Clinical Psychology, 1968, 22, 674-678.

Chapman, R. F., Snith, J. W. \& Iayden, T. A. Elinination of cigarette smoking by punishent and self-managerent iraining. Behaviour Researeh and Inerapy, 1971, 2, 255-264.

Cooper, K. H., Cey, G. O. \& Bottenberf; $R$. A. Effects of cigarette smokting on endurance performance. Journel of the American Medica 1 Association, 1968, 203, 189-192.

Elliott, R. \& Thysell, R. A note on smoking and heart rate. Psychophys lology, $1968,2,280-283$.

Elliott, R. \& Tighe, $T$. Breaking the cigarette habit: Effects of a technique involvirg threatened loss of money. Psychological Record, 1968, 18, 503-513.

Frickson, $K . H$. The burden of responsibllity in effective psychotherapy. American Jourral of Clinical Hypnosis, 1964, 6 , $269-271$.

Eysenck, H. J., Tarrant, W., hoolf, H., \& England, L. Smoking and personklity. Brjtish Medjca I Journe1, 1960, 1, 1456-1460.

Ford, S. \& Fderer, F. Breaking the clparette habit. Journal of the American Medical Associatson, 1965, 194, 139-142.

Franks, C. M., Fried, R. \& Ashen, B. An Improved epparatus for the averelve conditioning of cigarette smokers. Behaviour liescarch and Theran, $206,4,301-308$.

Freman, W. M. The altertiton of sexul referonees in the human male: A conditionine boreny ar le hunosemils. (Doctoral dissertation, Univerefty oi Lovisvile) hrm hrbor, Jichigan: 
University Mierofiums, 1972. No. 73-5812.

Gardrer, R. A test of covernt control therany to reduce cirarette sincking: A comprutue stuch of the exfectivenss of two

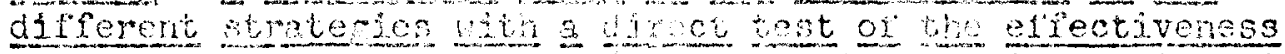
of continconcy mamecerent. (ioctoral disgcrtation, Unfversity of Loujsvilie) Ann Arbor, Michigzn: University Kicrofilins, 1971. ivo. 71-29, 132.

Gerson, P. \& Lanyon, R. I. Modification of moking behavior with an aversion-desensitization procedure. Joume of Consulting and Clnifce I Perchology, J.972, 38, 399-4,02.

Graff, H., Hamnett, V. B. O., Rash, N., Facliler, W., Yanovsk1, A., \& Goliman, $H$. Results of four ant,jusnoking herapy methods. Pennsylvanie Medical Joural, 1966, 69, 39-43.

Greene, R.J. Modification of smoking beksvior by free operant coriitioning methods. Psychological Pecord, 1964, 14, 171-178.

Griraldi, K. E. \& Ifchtenstein, E. Hot, smoky air as an aversive stimulus in the treatment of smoking. Pehavtour Research and Thesapy, 1969, 1, 275-280.

Gotmann, M. \& larston, A. Problems of $S$ is mutivation in, a beravioral program for reduction of cigarette smoking. Psychological Reports, $1967,20,1107-1114$.

Hayes, H. Statisticg for Psychologists. New York: Holt, Pinehart and Winsion, 1963.

Home, L. E. Perspectives in Psychology XXIV control of coverants, the operants of the mind. Psychological Record, 1965, 15., 501-511.

Hurt, W. A. Epilogue. Journal of Abnormal Psychology, 1973, 81, 196198.

Hunt, W. A. \& Matarazzo, J. D. Three years later: Recent developments in the experimental modification of smoking behavior. Journal of Abnome] Fsychology, 1973, 81, 107-114.

Hunt, W. A., Farnett, L. W. \& Branch, L. G. Relapse rates in addiction programs. Journal of Clinical Psychology, 1971, 27, 455-456.

Jacobs, M. A., Anderson, I. S., Champagne, E., Karush, N., R1chman, S., \& Knapp, P. Orality, inpulsivity and clgarette snoking in men: Further findings in support of a theory. Journal of Nervous and Mentai Disease, 1966, 1143, 207-219.

Kautzer, C.S. Behavior modificaiton of smoking: The experimental. Investigation of diverse techaiques. Behaviour Research and Therays, 1968 (a) $, 6,137-157$. 
Koenig, K.P. \& Masters, I. Expertmental treatment of habitual smoking. Behavfour Resegren and Thersu, 1965, 2, 235-243.

Kraft, I. \& 11 -Issa, I. Deseneititotion and reduction in clgarette consumption. Journal of Pevchology, 1067, 67, 323-329.

Lardy, E. E. Sex differences in some aspects of smoking behavior. Psychologica 1 Peports, 196\%, 20, 575-500.

Lawton, H. P. Group methods in smoking withdrawal. Archives of Environmental Health, 1967, 14, 258-265.

Leventinal, H., Watts, J. C., \& Fagano, F. Effocts of fear and instruetions on how to cope with danger. Joymel of Personality and Soojs] Psycholigy, 1967, 6, 313-321.

Ilchtenstein, E. Moification of enokin: behavicr: Good designs-inerfective treatments. Iournal of Consulting and clinical Psychology, 1971, 36, $163-166$.

Lichtenstein, E., Pousseint, A., Bergran, S., Jurney, T., \& Shapiro, $R$. A further report on the effects of the physicjan's treatIng of smoking by placebo. Diseases of the Nerrous System, $1967,28,754-755$.

Marston, A. R. \& McFall, R. M. Comparison of behavior modification approaches to whoking reduction. Journal of Consulting and C1snical psychologe, $1971,26,153-162$.

Mausner, B. Report on a smoking clinic. American Psychologist, 1966, 21, $251-255$.

Nausner, B. Some comments on the faflure of behavior therapy as a technique for modifyinf cigarette smoking. Journal of Consulting and Clinical Psychology, 1971, 36, 167-170.

Mausner, B. An ecological view of cigarette smoking. Journal of Abnormal Psycholorx, 1973, 81, 115-126.

McFall, R. M. Effects of self-monjtoring on nomal snoking benavior. Journal of Consulting and Clinfeal Psycholory, 1970, 35 , $135-14: 2$.

MeCuire, J.R. \& Vallance, M. Averston therapy by electric shock: A sinple technique. Britisi Medical Journal, 10,4, 1, 151-153.

Morganstern, K. P. \& Ratliff, R. G. Systematic decensitization as a technique for treating smoking behavior: A preliminary report. Behavioux Research and Therapy, 1969, 1, 397-98.

Moses, F.M. Treating smoking habt, by discussion and hypnosis. Dism eases of the Nexvous Systen, $1964,25,184-188$. 
Murphee, H. B., Prelffer, C. C. \& Frioe, I. M. Flectroencephalographte changes in man follontne smodnd. Anna]s of the Now York Acadeiny of Selerces, I867, $142,245-260$.

Nolan, J. D. Self-control procedures in the nodfficstion of moking behavior. Joury of Consulting and Clinioal Psycholory, 1968, 32, $92-93$.

Ober, D. C. Modification of smoking behavior. Journal of Gonsulting and Cltripel Psychology, 1968, 32, 543-549.

Platt, E. S., Kraussen, E. \& Mausner, B. Individusl variation in behavioral change following role playing. Pychological Peports, $1.569,214,155 \mathrm{k} 270$.

Powell, J. \& Azxin, N. The effects of shock as a purisher for cigarette nnokths. Journal of Lpritiea Behavioi Aralysis, 1968, 1 , 63 m 71 .

Premack, D. Tovard empirical behavior laws. I. Positive refinorcement. Peychologtcal Review, 1959, 66, 219-233.

Pyle, S., kgrew, N. M. \& Kopperud, J. Modification of an overlearned maladaptave response tinrough a rejeaming pogram: A pilot study on moking. Behaviour Research and Irerapg, 1966, 4, $197-203$.

Resnick, J.H. The control of smoling behavior by stimulus satiation. Behaviour Research and Therapy, $1968(\mathrm{a}), 6$, 113-114.

Resnick, J.H. Effects of stimulus satiation on the overlearned mala.. daptive response of cigarette snoking. Journal of Consulting and Clinical Psycholog, $1968(\mathrm{~b}), 22,501-505$.

Resnick, J. H. Hodification of smoking beherior: Good designs-Inaccurate reporting. Journal of Consultine and Clinteal P3ychology, 1971, 2i, 323.

Roberts, A. H. Self-control procedures in modification of sinoking behaviol:: Replication. Psycholopical Reports, 1969, 24, 675676.

Sachs, L. B., Bean, H. \& Morrow, J. E. Comparison of smoking treatments. Behavior Therapy, $1970,1,465-472$.

Schmahl, D. P. L1chtenstoin, B. \& Harris, D. E. Successful treatment of hobltual smokers with warn, moly air and rapid snoking. Journal of Consultine and Clinjeal Psycholog, 1972,38 , 1051.1.

Schwartu, J. L. \& Dubitzly, li. The smoktr control. research profect: Purpose, design, and initial results. Prychological Rororts, $1967,20,367-376$. 
Slplch, J. F., Russell, R. K. S Tobias, L. L. A comparfoon of covert senitization and "nonsrecteic" treacment in the modification of smoking behevtor. Jeurns? of Eehavior Therany and Dxpertmental Psychiatiry, 1974,2 , 201-203.

Steffy, R. A., Meichenbaum, D. Best, J. A. Aversive and cognttive factors in the modification of smoking behavior. Behaviour Research and Therapy, 1970, E, 115-126.

Streltzer, N. E. \& Koch, G. V. Influence of emotionsl role-playing on smoking habits and attitudes. Fsychojogleal Reports. $1968,22,817-320$.

Tooley, J. T. \& Pratt, S. An experimentai procedure for the exifnction of smoking behavior. Psychological Recoro, 1967, 17, 209-218.

Von Dedenroth, T. E. The use of hypnosis with "tubaccomaniacs". Anerican Journal of Clirijeal Hvenosis, $1964(\mathrm{a}), 6,326-331$.

Von Dedenroth, T. E. Further relp for the "tobaccomaniac." Amer1can Jourial of Clinical Hypnosis, 1964 (b), ó, 332-336.

Wejr, J. M., Dubitzly, M. \& Schwartz, J. L. Counselor style and group effectiveness in a smoking withiraral study. American Journal of Psychotherapy, 1909, 23, 106-118.

Witman, T. L. Modiflcation of chronic smoking behavior: A comparison of: three approaches. Behavioun Researcin and Therapy, 1959, 7, $257-263$.

Whitman, T. L. Aversfive control of smoking hehavior in a group con-text. Behaviour Fesearch and Therapy, 1972, 10, 97-104.

Widde, G. J.S. Behavior therepy for addicted cigarette snokers. Behaviour Ressach and Theraps, 1964, 2, 107-110.

Winer, B. J. Statistical princivles in experimentai destgn. Nev York: McGraw-Hi11, 1962.

Wolpe, J. \& Lazarus, A. A. Rehavion Thergex Techntques. New York: Pergamon Press, 1966. 


\section{VIRE}

Whe author, Gary ollve Salk, wo burn Karch 6,1944 in Detroit, Hicheren. itis secondary education wss completed in the Rochester Futum Iic school. Sytisn of Rochester, Wichigan in 1962. He then autended Michigan State Univerity from Septenber of that yoan until. jun of

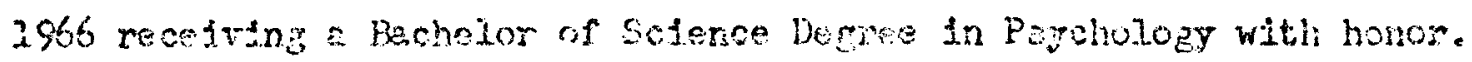

In February of 1967 he atseried the Universtty of Iowa in lows Cfiy, Iowi and in Angest of 2969 le recelved a Naster of Arts Dagree from the Universidy.

From sugust 1968 to hagust 2969 be worked for the themervice Center of cobvina, Jora on a researeh propect teachine himean relations

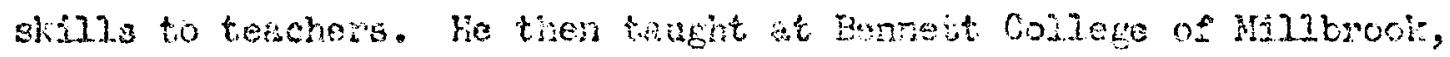

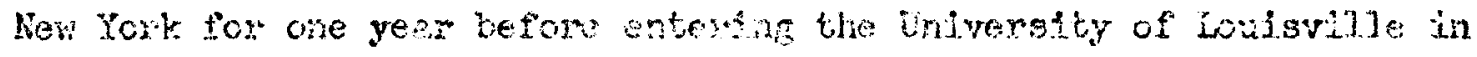
September of $19 \%$

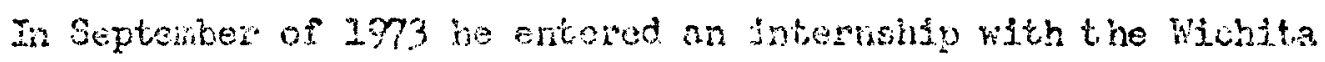

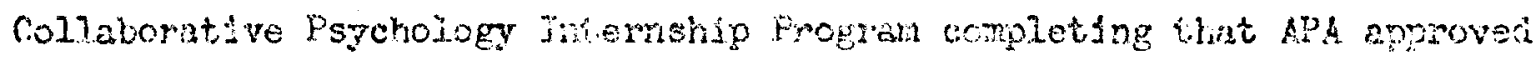
Internship in Auguet of 3974 . He is currentily employed as a Propologist with Wernerevilio Steta hospltal, Vernersuljle, Pennsylvania. 